KAPL, Inc.

\author{
SPACE REACTOR MATERIALS \\ MATERIALS DEVELOPMENT ORGANIZATION
}

SPACE MATERIALS MEMORANDUM

\title{
TITLE: $\quad$ Naval Reactors Prime Contractor Team (NRPCT) Experiences and Considerations with Irradiation Test Performance in an International Environment.
}

\author{
AUTHOR: $\quad$ Michael Lane, Principal Engineer \\ Space Materials Testing \\ Materials Development Operation \\ DATE: $\quad$ February 15, 2006
}

This letter forwards a compilation of knowledge gained regarding international interactions and issues associated with Project Prometheus. The following topics are discussed herein:

- Assessment of international fast reactor capability and availability

- Japanese fast reactor (JOYO) contracting strategy

- NRPCT/Program Office international contract follow

- Completion of the Japan Atomic Energy Agency (JAEA)/Pacific Northwest National Laboratory (PNNL) contract for manufacture of reactor test components

- US/Japanese Departmental interactions and required Treaties and Agreements

- Non-technical details - interactions and considerations

\section{Background}

The NRPCT was evaluating many unique structural materials for applicability to Project Prometheus. For these materials, minimal irradiation data exists for prototypic conditions expected in a Prometheus reactor. In an effort to quickly build an irradiated properties database, irradiation test platforms were investigated worldwide. The NRPCT contracted with PNNL to perform a feasibility assessment for conducting a high fluence radiation test in foreign test reactors. This assessment is summarized in Enclosure 1. Recommendations made by PNNL were based on a combination of facility capabilities and timing of available insertions. The NRPCT, aided by PNNL's assessment, concluded that of the available reactors worldwide, the Experimental Fast Reactor JOYO (located in O-arai, Japan) was the best facility to pursue for irradiation testing. JOYO is operated by JAEA, the agency recently formed from a merger of the Japan Atomic Energy Research Institute (JAERI) and the Japan Nuclear Cycle Development Institute (JNC). Further, PNNL identified the BOR-60 Reactor located in Dimitrovgrad, Russia, as the next best option. However, less progress had been made with investigating BOR-60 prior to the termination of NR Program involvement in Project Prometheus. 
To perform irradiation testing in JOYO, the NRPCT contracted with PNNL to: (1) act as a liaison with JAEA, (2) utilize their irradiation test engineering experience, and (3) take advantage of their foreign contracting experience. This document provides NRPCT experiences, including insights into relationships, interactions, required documents, regulations and nuances associated with contracting with a foreign entity such as JAEA.

\section{Assessment of International Fast Reactor Capability and Availability}

Obtaining irradiation data on fuel and candidate structural materials, as well as subscale fuel elements, required investigation of various irradiation test platforms to support Project Prometheus. Schedules associated with Prometheus required that irradiation data from prototypical neutron energy spectrum tests be obtained as quickly as possible. Testing in fast reactors was necessary as they would have provided both a means of accelerating testing, as well as a near prototypic neutron spectra needed to obtain irradiated material performance data to support Prometheus material selections.

PNNL's foreign reactor assessment identified the Experimental Fast Reactor JOYO in O-arai, Japan as the best facility to perform materials irradiation tests needed to support Prometheus when compared to BOR-60 (Russia), Fast Breeder Test Reactor (India), Monju (Japan), Phénix Reactors (France) and various thermal reactors. The irradiation platforms that were evaluated are summarized below. A first phase of structural materials testing was initiated, referred to as JOYO-1, which was designed to screen various candidate materials. It was understood that JOYO-1 testing alone would not provide all Prometheus irradiation test data needs and future JOYO campaigns were also being pursued (JOYO-2 in late 2007/early 2008 and JOYO-3 in 2010). Additional testing in other platforms was also in the initial investigation stages.

Testing in Oak Ridge National Laboratory's (ORNL) High Flux Isotope Reactor (HFIR) was also underway [Reference (a)]. HFIR was screening several materials, but was envisioned to be mainly used to irradiate materials that do not transmutate in the presence of thermal irradiation. HFIR has a peak fast flux about half that of JOYO. However, testing of structural materials in HFIR would have required insertion in the reduced flux "Removable Beryllium (RB*)" region to minimize transmutation and thermal neutron effects through shielding. Due to the reduced flux in this region, it was expected that achieving prototypical end-of-life (EOL) fluences would take about 10 times longer than testing in JOYO. Comparatively, the test duration necessary to obtain a similar fluence in the Advanced Test Reactor (ATR) at Idaho National Laboratory (INL) is also roughly a factor of ten longer, again due to a lower fast flux. Scheduler challenges with irradiation campaigns in HFIR and ATR reactor were exacerbated by additional design complexity of overcoming unwanted thermal spectral effects, whereas commencing international fast reactor tests were challenging due to longer than expected test coordination, permitting and construction times.

\section{JOYO}

JOYO is part of the O-arai Engineering Center (OEC), operated by JAEA, a government-owned corporation located in O-arai, Japan. JAEA reports to two government agencies, the Ministry of Education, Culture, Sports, Science and Technology (MEXT) and the Ministry of Economy, Trade and Industry (METI). In terms of size and fast flux, JOYO's rated power is $140 \mathrm{MW}_{\mathrm{t}}$, and peak fast flux is $4.0 \times 10^{15} \mathrm{n} / \mathrm{cm}^{2}$-s. JOYO is a loop-type sodium-cooled Liquid Metal Reactor (LMR) that utilizes a Mixed Oxide Fuel (MOX). The reactor operating cycle is 60 Effective Full Power Days (EFPD), with approximately 20 days between cycles for refueling and experiment handling. The nominal operating schedule includes five cycles per year followed by 
approximately six to twelve months of down time for inspections and maintenance. A significant number of irradiation experiments have been conducted in JOYO, and a vigorous testing program was expected for Project Prometheus. Most of the testing is associated with Japanese LMR fuel and cladding development, but there have been a number of other programs.

Although most of JOYO's customers are Japanese, joint irradiation studies with foreign partners such as France and the US (including Battelle) have been conducted. Japan and the US currently have in place a bi-lateral agreement under Section 123 of the Atomic Energy Act, allowing safeguarded exchange of commercial nuclear power technology and nuclear materials for peaceful uses.

\section{BOR-60}

BOR-60, a $60 \mathrm{MW} / 12 \mathrm{MW}_{\mathrm{e}}$ loop-type sodium-cooled LMR, has a comparable fast flux region spectrum to JOYO. BOR-60 was considered a potential alternative to supplement testing in JOYO. BOR-60 is located at the Research Institute for Atomic Reactors (RIAR) in Dimitrovgrad, Russia. Although the BOR-60 peak fast flux at rated full power of $60 \mathrm{MW}_{\mathrm{t}}$ is $3.3 \times 10^{15} \mathrm{n} / \mathrm{cm}^{2}-\mathrm{s}$, the reactor typically operates at about $52 \mathrm{MW}_{\mathrm{t}}$, resulting in an effective peak core region fast flux of $2.85 \times 10^{15} \mathrm{n} / \mathrm{cm}^{2}$-s. In comparison, JOYO is a $140 \mathrm{MW}_{\mathrm{t}}$ reactor with a peak fast flux of $4.0 \mathrm{x}$ $10^{15} \mathrm{n} / \mathrm{cm}^{2}$-s in-core and $1.9 \times 10^{15} \mathrm{n} / \mathrm{cm}^{2}-\mathrm{s}$ in the reflector region. BOR-60 operates at power for five 50-day cycles (fast fluence of $64.8-112.3 \times 10^{20} \mathrm{n} / \mathrm{cm}^{2}$ accumulated per cycle) throughout one operating year with scheduled refueling shut-downs. This reactor can achieve expected Prometheus EOL fast fluences within 100 days, although volumes of the irradiation rigs are not as large as JOYO ( four BOR-60 rigs to each JOYO rig). PNNL has successfully used BOR-60 for irradiation testing of structural materials, however, shipping between the US and Russia has been problematic.

\section{Fast Breeder Test Reactor}

Fast Breeder Test Reactor (FBTR), located at the Indira Ghandi Centre for Atomic Research (IGCAR), Kalpakkam, India, is a loop-type sodium-cooled fast breeder reactor that utilizes mixed carbide $\left(\mathrm{UC}_{2} / \mathrm{PuC}\right)$ fuel. FBTR has been used extensively by Indian researchers for irradiation test campaigns, including a variety of fuel types (carbide, oxide, and nitride), core structural materials (austenitic stainless steels as well as ferritic / martensitic steels), and zircaloy (for heavy water reactor pressure tube applications). However, FBTR has not been used as an irradiation test platform by foreign customers due to export control issues. Hot cell facilities at IGCAR are quite extensive and include all standard fuel and structural materials test and examination capabilities. FBTR is a small reactor operated at a full-power level limited to approximately $12 \mathrm{MW}_{\mathrm{t}}$, thereby providing a peak fast flux of only $1 \times 10^{15} \mathrm{n} / \mathrm{cm}^{2}$-s. Therefore, the FBTR facility for irradiation of fuels or materials would require longer irradiations to achieve desired fast fluences. The small core size may limit available volume for irradiation experiments.

\section{Monju}

Located in Japan and currently inactive, Monju is a sodium-cooled fast breeder reactor that utilizes MOX fuel. It has a rated power of $714 \mathrm{MW}_{\mathrm{t}}$ and $280 \mathrm{MW}_{\mathrm{e}}$ and a design rod-average fuel burn-up of $80 \mathrm{GWd} / \mathrm{t}$. Peak fast fluxes are $6.0 \times 10^{15} \mathrm{n} / \mathrm{cm}^{2}$-s. Monju achieved initial criticality in 1994 but during its run-up to full operation in 1995, it experienced a secondary-side sodium leak that resulted in the reactor being shut down for over ten years. Monju has been maintained in a hot standby condition since that time. Local government approval to restart has recently been granted, and approximately 17 months of safety modifications followed by two years of pre- 
operational testing are projected before restarting the reactor. Neither irradiation vehicles nor an irradiation testing infrastructure currently exist at Monju and would have to be designed and licensed prior to use. Lead time for these activities is estimated by JAEA at 4-5 years. Therefore, Monju is not a viable irradiation test vehicle in the near term and the extent to which it could be a materials irradiation test vehicle in the long term is not presently known.

\section{Phénix}

Phénix is a pool-type sodium-cooled fast reactor operated by the Commissariat à íÉnergie Atomique (CEA) in Marcoule, France, that utilizes MOX fuel. Phénix's mission includes irradiation testing to support research for actinide burning and waste transmutation. A law was passed by the French government limiting operation of Phénix until its present supply of driver fuel is exhausted. Accordingly, a specified number of EFPDs remain in its operational lifetime. In general, Phénix will operate for 240 EFPD per year (two 120 EFPD cycles), until a permanent shut down in 2007. Although Phénix currently operates at a reduced power level of $320 \mathrm{MW}_{\mathrm{t}} / 142 \mathrm{MW}_{\mathrm{e}}$ with a peak fast flux ranges of 4.4 to $7.5 \times 10^{15} \mathrm{n} / \mathrm{cm}^{2}$-s, it is higher than all other currently operating fast reactors. Officially, CEA is not accepting new experiments for Phénix, but space may have been available on an ad-hoc basis. Post Irradiation Examination (PIE) capabilities at Phénix are extensive and further detailed in Enclosure 1. Because of the operational schedule, Phénix was not considered a viable option for irradiation testing.

Given appropriate approvals, classified fuels or materials may be irradiated in the Phénix fast reactor. A bilateral agreement is currently in place with US DOE and government agencies in France under Section 144 of the Atomic Energy Act (also known as a Mutual Defense Agreement, or MDA) defining acceptable classified activities or exchanges of classified materials between the US and France.

\section{Contracting Strategy for JOYO-1 Irradiation Test}

During late 2004 and into 2005, the NRPCT pursued an aggressive irradiation test strategy supporting Prometheus 1 that included using JOYO. JOYO was available to provide timely fluence data for non-fuel candidate materials with a near prototypical neutron spectrum. A June to November 2006 availability was targeted for the first of a series of irradiation tests using the JOYO reactor. Following this initial test period, JAEA would begin a year long inspection of JOYO before resuming operation in 2008. If the JOYO-1 test specimens were not inserted in time to support the June 2006 irradiation, a one and a half year delay would have resulted waiting for the next reactor availability. It was imperative that a contract be quickly placed with JAEA to support this date.

To meet required contract placement timing with JAEA, NRPCT evaluated two options: (1) have NRPCT place a contract directly with JAEA and (2) contract with a national laboratory to place a contract with JAEA.

Option 1 required NRPCT to devote a significant amount of resources to facilitate an international contract because the NRPCT contracting experience base is primarily domestic. The time required to acquire the appropriate personnel and gain the basic international knowledge was considered incompatible with the expedited NRPCT schedule for meeting the JOYO June 2006 irradiation start. Further, any existing employees with some overseas contracting expertise could not be applied to this effort without significantly impacting other nonSpace work conducted at the NRPCT sites. 
Option 2 allowed NRPCT to leverage its limited international contracting experience by hiring a contractor to execute the JAEA contract, including researching and understanding appropriate international contract law. In addition to meeting schedule, hiring a contractor with Japanese contracting experience enhanced the understanding of Japanese cultural and business practices, which are very different from those in the United States. US DOE guidance on interagency work orders for contracting [Reference (b)] states that an Inter-Contractor Purchase is appropriate only when the performing contractor has special or unique experience in this area. In others words, the contractor must provide value to the work and not just a conduit for the work.

In Reference (c), the NRPCT recommended that PNNL be contracted to facilitate the JOYO-1 irradiation testing program contract with JAEA for the NRPCT. The NRPCT selected PNNL for several reasons:

1. PNNL had recently conducted a review of fast spectrum test reactors and provided NRPCT a recommendation to pursue JOYO.

2. PNNL has experience in overseas irradiation programs such as JOYO and BOR-60

3. PNNL has experience in placing contracts with international firms, including an understanding of the appropriate export control laws.

4. PNNL has personnel integrated in the Japanese culture, both technically and socially, that provide guidance to support face-to-face interactions needed to develop the test program.

Following approval, the NRPCT contracted with PNNL who in turn, placed a contact with JAEA to perform required precursor items for the irradiation work to follow. PNNL also acted as a communication liaison and reviewed JAEA quality program(s), import/export issues, and shipping. The National Aeronautics and Space Administration (NASA) restructured the Prometheus Program and, therefore, the NRPCT program involvement in Prometheus was cancelled prior to contract placement for the actual irradiation testing in the JOYO reactor.

Overall program management for irradiation testing in JOYO resided with the NRPCT. The NRPCT performed all test sponsor functions (test matrix design, test requirement/ conditions definition, activity coordination, and fabrication/delivery of test specimens, etc.) along with designing and building test capsules. Due to their experience with foreign irradiation work, PNNL was used to place contracts with JAEA and facilitate transfer of technical information and quality requirements between JAEA and NRPCT. PNNL also arranged for necessary export licenses and was to facilitate specimen shipping arrangements. During the contracting effort, PNNL utilized an established relationship between Battelle and Mitsubishi to help with language and legal issues. There may be other entities that could have performed PNNL's role, but PNNL was judged to be in the best position to effectively facilitate this first phase of work. A summary of PNNL's involvement in JOYO contracting is included in Enclosure 2. As experience and confidence in working in the Japanese culture was realized, the NRPCT planned to reconsider the need for an interim contracting and liaison agency for future work efforts beyond the initial JOYO-1 irradiation testing.

\section{NRPCT / Program Office International Contracting}

International contracting presents a unique set of considerations and challenges, which may not be readily apparent to individuals solely familiar with domestic Government contracting processes. Several issues must be evaluated and understood if a company is going to practice international trade. If multiple contracts or a continuing, ongoing international relationship is 
desired, it is recommended to develop or obtain in-house expertise with international contracting, as well as international law. If this expertise is not currently present or readily available in-house, employing a national laboratory or agency which has this expertise should be considered. When employing a third party as an interface, costs associated with direct charges as well as burdens or fees applied to overseas charges should be fully understood.

As described later, nuclear work performed overseas will likely require some form of an International Agreement that is approved by the US and the associated foreign government. If not currently in force, these types of agreements typically take in excess of a year to establish. Test plans should incorporate the schedule required to establish (or modify) such agreements for specific work scope. Additionally, some types of agreements require the involvement of other federal organizations (e.g., US Department of Commence (DOC) or DOS). The specific Memorandum of Agreement being pursued for the JOYO testing did not require the review and approval of agencies other than US DOE. In the case of JOYO testing, Japanese Governmental approvals and a licensing fee were required to be paid to MEXT to support structural analysis reviews of rigs, reviews of rig parts material certification paper work and final inspection during the SMIR assembly.

For an experiment in the core of the reactor, the materials and test conditions must fit within the existing licensing basis. The licensing basis for JOYO is shown in Appendix A of Enclosure 2. In general, the licensing basis is relatively narrow, mostly encompassing fuels and cladding materials for fast reactors. There are few issues for structural materials but licensing for fuels is very specific. In particular, JAEA has never irradiated fuels in the double-encapsulated arrangement that is typical of the NR Program design. As a result, most experiments in the core will require a license amendment from the Japan nuclear regulator. While there is no specific list of prohibited materials, each experiment is considered on a case-by-case basis with regard to the licensing basis and safety impact. Applications for licensing approval typically are not filed until the conceptual design is complete. Detailed design and procurement of materials proceed in parallel with the licensing process. After licensing, the test specimen (fuel or structural materials) and irradiation vehicle fabrication activities begin. A fuel experiment that does not need a new license would require a minimum 3 year lead time for planning; more for one that does. As shown in Enclosure 2, planning for structural materials irradiation tests require somewhat less lead time. The JOYO experimenter's handbook explains the irradiation testing design and analysis approach required for license amendment applications, but it is available only in Japanese.

There are many dynamics in dealing with a foreign entity on a technical level. It is crucial to fully understand the contracting, agreement, and approval processes. As an example, PNNL took for granted information provided with respect to the path forward for establishing a US/Japan agreement. PNNL later found out that the approval agency of the Japanese government did not agree with the process established by JAEA for the needed agreements. The lesson learned was that PNNL should have requested a written plan be understood, established, and agreed to by JAEA/MEXT as to how proceed with the agreement. Consideration should be given to establishing the written plan as a contractual line item to assure that JAEA provides the plan needed to go forward.

\section{Budget and Schedule Control}

For those programs involving international contractors, careful budget and scheduler control is of utmost importance. All stakeholders must agree on a base date for terms of locking-in contract currency exchange rates. For contracts involving NRPCT, this information was defined 
up-front during contract negotiations. Thus, exchange rates could vary up or down during the performance period, yet costs would be fixed based on a set (agreed upon) exchange rate. NRPCT and PNNL established a weekly conference call using an agreed to agenda to ensure issues were being worked to avoid potential schedule impact. These practices maximized the call efficiency and usefulness.

\section{Program Management}

Overall program management resided with the NRPCT. One control routinely implemented in NRPCT programs are electronic monthly vendor progress reports. NRPCT required that these progress reports provide status of progress toward parts procurements and other defined deliverables. The reports also identified any issues of concern and a description of intended resolution. A defined due date for the monthly reports was contractually specified. Posting the reports electronically on Ciphershare (see "Communications with Domestic Subcontractors" section) allowed for their timely review.

\section{Quality Issues}

An important aspect is project quality assurance (QA) requirements. Project $Q A$ requirements in-place at vendors should be carefully compared with the overarching quality system (e.g., Code of Federal Regulations (CFR) 10CFR830, Nuclear Safety Management; Subpart A, Quality Assurance Requirements; or International Organization for Standards (ISO) 9001, Quality Management Systems - Requirements), including appropriate higher-tier specifications as well local procedures or instructions. Comparison of requirements and systems would reveal whether proposed vendors (e.g., NASA, national laboratory, and contractor) are capable of performing work to quality requirements equal to or greater than those required. NRPCT also recommends that quality assurance activities, processes and controls associated with specific elements of programmatic work be discussed up-front and locked in prior to contract placement. Regardless of systems in place, key project technical personnel that are ultimately responsible to ensure appropriate controls (such as quality assurance plans, technical reviews, data validation, etc.) are specified in contractual programmatic documents. Additionally, the JAEA QA Program Plan (Manual) did not exist in English and required translation.

Dealing with an overseas supplier can pose unique difficulties with quality issues, as standard business practices in foreign countries are not always the same as here in the US. Contractors are usually bound to follow all required regulatory and company internal $Q A$ requirements during contract performance. Careful consideration should also be given to implementing design review processes into contractual documents. One or more (if needed) design reviews should be planned, as appropriate. Extent and scope of the reviews should be well described and reviewed by all participating parties with care and detail taken to avoid any misunderstandings. For JOYO contractual deliverables, NRPCT planned both a $50 \%$ and $95 \%$ design review for the specimen capsule design. A 50\% design review was held with JAEA and since issues were well understood by all parties, JAEA considered the $95 \%$ design review as unnecessary [Reference (e)]. NRPCT, however, intended to hold an internal 95\% review to cover these aspects. JAEA could not issue a formal report to accept the final capsule design until the Irradiation Contract was finalized. This report was to exclusively focus on the safety aspects of capsule design and was submitted to MEXT for approval to perform irradiation testing, but never issued due to the project termination.

Source inspection(s) should likewise be planned, but not necessarily just for deliverable completion. Source inspections are performed on-site as verification to assure satisfactory 
completion, inspection, testing and certification of all parts and components based on physical verification and review of applicable documentation. Interim progress inspections may also be warranted based on item criticality and may be combined with other on-site meetings.

\section{Access to Information}

From Reference (f), JAEA would have access to materials, test, and post-irradiation examination data (if PIE performed in their facilities). However, JAEA was not allowed to publish or use data in anyway. PNNL would be familiar with materials and test conditions. As procedures for transfer/transmittal of test data were to be further defined, NRPCT would have pursued direct throughput from JAEA, minimizing PNNL data access. JAEA needed to know expected internal capsule temperatures and to accept the design; they needed to know how NRPCT calculations were conducted. In the unlikely event that JAEA performed all of the PIE work, they would then have had access to that information.

To protect against potential use of information by JAEA, a typical nondisclosure of intellectual information presided. Overarching words on data rights were also included in US/Japan agreements. PNNL/JAEA contract wording similar to prior NRPCT contracts was used. The contract contained a standard agreement stating that information gained is owned by the NR program and may not be published or used to benefit the research organization.

On the other hand, access to information needed by the NRPCT to support design iterations for the test capsules was limited at times because JAEA was not able to provide technical details of reactor conditions without a signed agreement between the US and Japan. In lieu of having these agreements in force, the only viable method for acquiring information was at face-to-face meetings and public release of the information by JAEA.

\section{Public Utterances}

Matters of public release of information related to work under the order should be addressed in the earliest stages of fact-finding and subsequent contract negotiations. It will be necessary to balance Government policy (i.e., Department of Energy policy and Japanese Government policy) to provide to the public and the news media, accurate and timely unclassified information on policies, programs, and activities versus programmatic needs (i.e., Naval Reactors) to limit the dissemination of information. An early and full assessment of the risk posed through release of work related information (while recognizing that all information will not be known at the outset of a research program) will determine the latitude the parties will have for the open exchange of information.

The contractual language negotiated with JAEA concerning public utterances is included in Attachment 1. NRPCT considers that obtaining public utterance approvals was typically burdensome from a timing perspective, where standard NR Program practice is an eight week approval cycle for subcontractors. This was especially evident for JAEA Press Releases and multiple presentations / papers for conferences that both PNNL and NRPCT were to attend. For JAEA public utterances, NRPCT gained approval through the typical cycle when schedules allowed, but JAEA occasionally proposed modifications to the approved wording and asked for immediate (same day) turn-around. NRPCT frequently improved upon the normal cycle and met JAEA's needs, to promote goodwill between the parties. An improved understanding of the issues at hand from all involved parties may help in future streamlining of this important program aspect. 


\section{Nuclear Indemnification}

Typical of contracting nuclear related work is the matter of nuclear indemnification. PNNL recommended that a new separate agreement include language that dealt with nuclear indemnification, which would eliminate a US DOE requirement for PNNL to pass down the Nuclear Hazard Indemnity Clause to JAEA. Provided in Enclosure 3, this recommendation proposed language that each party relies upon its own national law to provide compensation for damages to itself arising from activities under this agreement and will not look to the other party for such compensation. Copies of the Nuclear Hazard Indemnity Clause and the Price Anderson Amendments Act of 1999 are also included in Enclosure 3 along with a NRC Assessment of the Price - Anderson Amendments Act. Passing down the Nuclear Hazard Indemnity Clause would require JAEA compliance to 10 CFR 830.120 quality requirements, and although not finalized prior to program termination, was recommended as not required, although this point was not completely agreed upon by all parties.

\section{Completion of JAEA/PNNL Contract for Manufacture of SMIRs}

In May 2005, PNNL contracted with JAEA to manufacture two Structural Material Irradiation Rigs (SMIRs). Following the cancellation of NRPCT involvement with Project Prometheus in September 2005, NRPCT and PNNL concluded that it would not benefit NRPCT to terminate the SMIR fabrication contract. This decision was made from both a cost standpoint where no substantial cost savings from a premature termination would result and it may potentially jeopardize working relationships established over the last year. Therefore, the two SMIRs were fabricated and delivered to JAEA in January 2006. The SMIR hardware, however, was to remain JAEA property unless an alternate US DOE use was identified by 1/20/06. NRPCT and PNNL made initial contacts and presentations/discussions took place with prospective suitors [Generation IV Nuclear Energy Systems Initiative and Advanced Fuel Cycle Initiative (GEN-IV and $\mathrm{AFCl}$ )] as described in Enclosure 8 of Reference $(\mathrm{g})$. Although interested, these entities did not have the 2006 budget flexibility to take on such an extensive program as NRPCT had established for JOYO-1. Additionally, NRPCT (through PNNL) had placed a contract for purchasing long lead materials to fabricate two additional SMIRs, for use in JOYO Cycles 7 and 8 irradiation testing in 2007/2008. This contract was cancelled prior to any use of funds.

\section{International Treaties /Memorandums Of Agreements -MEXT/US DOE Interactions}

As many governmental and institutional understandings and agreements are likely required for international nuclear related testing, it can become complicated to fully understand the interactions and overriding documents. It proved helpful in understanding these bi-lateral interactions by creating a flow chart (see Attachment 2) showing a treaty/ agreement /document hierarchy as well as a hierarchy of organizations. The hierarchy of treaties and/or agreements used to complete this type of work typically has three levels. In proceeding with international contracting work, the US DOE Office of International Affairs would decide what type of agreement(s) is required. To cover proposed work, one must first determine if higher-tier, international treaties or agreements exist between the subject countries and how they might apply. One longstanding, overarching treaty that has been ratified by both the United States Government and the Government of Japan pertaining to the Prometheus work is "Principles Governing Activities of States in the Exploration and Use of Outer Space, including the Moon and other Celestial Bodies of January 27, 1967." 
In review of existing mid-level documents, it was concluded that "Peaceful Uses Agreement" and the "Nuclear Technologies Agreement" were in effect and that proposed irradiation experiments for JOYO-1 can and need be performed within the bounds of these agreements. Effective periods in force for these documents must be understood as some may become obsolete over time.

The Peaceful Uses agreement requires the US to declare that the data will be used in a nonmilitary way - in this case space exploration. This was originally an issue as JAEA recognized that NRPCT had government (military) connections as it supports the US Nuclear Navy. US DOE, through the Office of Naval Reactors, supplied this requested information, documenting that funding was from NASA and additional agreements were in place within the US to separate this information from potential military application. Supplying such information, however, can sometimes involve the US DOS. An example of a similar request involved a NRPCT contract with a United Kingdom (UK) vendor (Meggitt Ltd., Heatric Division) to design a gas cooler heat exchanger for Project Prometheus. Nearing the end of the contract work, NRPCT was made aware by Heatric that abiding by the U.S.-Euratom Agreement for Peaceful Nuclear Cooperation $^{3}$ is required when technology is transferred between the US and UK nuclear industry. Assurance that the agreement was met required formal written exchange between the US DOS and UK Department of Trade and Industry. This unanticipated international governmental exchange significantly impacted the product delivery from Heatric to NRPCT. Engaging the US DOS and UK Department of Trade and Industry immediately following contract placement would have been prudent to mitigate schedular delays. Responding to US DOS (or another department) in situations like this requires involvement directly through the Office of Naval Reactors and US DOE.

Under the US/Japan Nuclear Technologies Agreement (NTA), it was also determined that a lower-tier document or a Specific Memorandum of Agreement (SMA) was needed to cover specifics related to irradiation of structural materials supporting a space reactor development program. However, the then current NTA expired on August 22, 2005 prior to amendment with the proposed SMA. This SMA was to establish a framework for cooperation between US DOE, through its Office of Naval Reactors (NR), and JAEA for utilization of JAEA facilities and subcontractors to conduct nuclear reactor fuels and materials testing for NR's responsibility to deliver space reactors for NASA. Discussions early on with both US DOE-NE (Nuclear Energy, Science and Technology Program Office that originated the NTA) and JAEA indicated that an SMA could be issued prior to August $22^{\text {nd }}$ and be effective for the duration of the SMA as agreed to by both parties.

A draft SMA to address requirements of the NTA for the specific work to be accomplished was reviewed with US DOE. The US DOE General Council reviewed the proposed agreement as well as decided if other US Government organizations (i.e., US DOS, NASA) needed to review. Development of any international agreement also required close coordination with the Office of

\footnotetext{
1 “Agreement for Cooperation between the Government of the United States of America and the Government of Japan concerning peaceful uses of Nuclear Energy (Nov. 4, 1987).”

2 "Agreement between of the Department of Energy of the United States of America and the Japan Nuclear Cycle Development Institute in the field of Nuclear Technologies.”

${ }^{3}$ This agreement is summarized as stating "US/UK technology transfer will not be used for any nuclear explosive or other military purpose, or the technology or items produced through its use will not be retransferred without the prior consent of the British Government.”
} 
International Science and Technology Cooperation (IP-31 $\left.{ }^{4}\right)$. Naval Reactors consultation with IP-31 yielded a final version of the SMA which in turn was provided to JAEA as a draft for review and comment. After several discussions between Naval Reactors, JAEA and US DOE-Tokyo (used as an intermediary to facilitate discussions), agreement was reached as to appropriate language to be included in the SMA. JAEA then forwarded the draft SMA to MEXT at which point MEXT raised several issues, details of which were not clearly communicated. Therefore, only speculation of their concern(s) can be described herein. A typical SMA review cycle at JAEA takes about two months while an additional several months would be required for Japanese Governmental review. A (final) copy of the proposed SMA is included in Appendix $F$ of Enclosure 3.

Separate from this project, the US DOE had undertaken a complete review of all international agreements between US DOE and foreign entities. Pending completion of this review, new agreements would be undertaken and extending existing agreements was suspended. US DOE-NR obtained the Secretary of US DOE agreement to proceed with an SMA under the existing NTA agreement. To the surprise of JAEA, after months of JAEA working on an SMA with US DOE-NR, MEXT did not agree with the SMA approach and requested US DOE establish a new agreement with JAEA (or a renewal of the overarching NTA). MEXT's position was that any future cooperation between US DOE and JAEA in the area of space reactor development work should be consistent with this new US DOE-JAEA agreement. With this approach and the lead time it would take to ratify such an agreement (i.e., 1-1 1/2 years), it was likely that inserting advanced structural material specimens into JOYO Cycle 5 would have been missed. JAEA and NRPCT/US DOE were working on alternatives and a path forward to ink this needed cooperative agreement when NRPCT's involvement with Prometheus was cancelled. From a NRPCT/ US DOE perspective, the most likely alternative was that a SMA similar to the one "finalized" in Appendix F of Enclosure 3 would be drafted under another treaty or agreement. Additional details on the proposed agreements and potential effects of the JNC/JAERI merger are included in Reference $(\mathrm{h})$. The project was restructured shortly after the MEXT decision to not accept an SMA under the existing NTA and a path forward to resolve this obstacle was not established.

\section{Non-technical details - Interactions and Considerations}

A key ingredient to contracting success is to maintain open communications among all stakeholders. One way to initiate this is to hold an early "meet-and-greet" meeting between stakeholder management as well as key individual contributors involved. If held at a vendor facility, this meeting could commence with a series of presentations discussing vendor capabilities, facilities, similar programmatic efforts, and available personnel skills (e.g., project lead, contracting, technical, legal, quality assurance, administrative) that would support the project. Subsequent to formal presentations and a question/answer session, facility tours should be held to provide a first-hand perspective of laboratory (or vendor) capability, conditions (e.g., state of equipment and cleanliness) and processes. Tours are an excellent method to assess whether activities "on the shop floor" are consistent with documented processes.

Integrated work management processes such as work scope definition, hazard analysis, hazard control implementation, performance of work, and assessing results should also be reviewed. Typical work instructions, data forms, data records and training records should be reviewed as part of laboratory tours.

\footnotetext{
${ }^{4}$ Enclosure 2 of this report refers to the designation of the US DOE Office of International Science and Technology Cooperation as IA-41. IP-31 is the current designation.
} 


\section{Kick-off Meeting}

The following approach worked for the NRPCT in these efforts. Once a contracting and performance plan has been conceptualized, a face-to-face kick-off meeting was held between project members and cognizant vendor(s) and/or subcontractors.

A typical agenda is as follows:

- Introduction and overview of meeting objectives

- Roles and responsibilities [of stakeholders]

- Technical issues

- Contracting issues

- Review any future meetings or trips

o Finalize draft agendas

o Review travel logistics

- Summarize meeting results and agreements

These meetings were thoroughly documented prior to the meeting conclusion via an agreed upon format. Thus, any misunderstanding(s) could be resolved before stakeholders return to their respective sites and their respective positions subsequently become established.

Additionally, a documented list of open items was developed including specific tasks, names of responsible individuals and estimated or actual completion dates. This open-items list was periodically maintained and reissued, as appropriate (i.e., weekly or bi-weekly). In terms of interactions and understandings, there is no substitute for formalized communications and documentation. Thus, any agreements made during kick-off meetings were formally documented in writing with all parties agreeing with the text prior to meeting adjournment. Agreed to meeting minutes, including these agreements are typically made contractual when issued via IV.

For overseas meetings, an interpreter may be warranted to overcome any language barriers. For NRPCT visits to JAEA, the use of an interpreter was helpful for contractual details and meeting wrap-ups. Technical meetings went reasonably well without an interpreter. US DOETokyo aided in securing interpreter services and suggests that if sensitive issues exist, a USbased interpreter be used. US DOE-Tokyo used SIMUL International (Tel: 03-353-93791) for this service. Additionally, a visa is not required for stays less than 90 days. Entry into Japan requires a valid US tourist (blue cover) passport. Country clearances may be facilitated through a local US DOE office.

\section{Communications with Domestic Subcontractors}

An important aspect of managing work with domestic subcontractors is to maintain continued open communication from a technical, as well as financial and scheduler point of view. NRPCT considered that communications with PNNL were largely adequate, although a few instances required improved control and follow. NRPCT needed to better monitor durations of some PNNL task efforts, as slipping dates could have jeopardized Program credibility with JAEA. A major aid in communication to NRPCT was the introduction of "Ciphershare", a software program that allows a transfer of unclassified data and email between "trusted" users. Personnel on travel to various locations could access Ciphershare via any hotel internet node and even while visiting foreign countries. Vendors / subcontractors typically posted both technical and month end review/ budget reports along with periodic email communications on Ciphershare. This proved invaluable to improved communications given time zone differences 
and time away from one's normal office due to substantial travel schedules. Implementation of Ciphershare did not come without drawbacks, however. NRPCT would have benefited from use of additional security officers to sign people on to the system and to have more users in each unit. This would have minimized the use of individuals in other units to accomplish these tasks. Additionally, PNNL commented that they typically transmit unclassified information relatively freely, and the use of Ciphershare for them was more burdensome.

Another communication aid that proved worthy was a weekly management telecon, held at the same time each week to avoid scheduling issues. These conference calls contained programmatic progress and status as well as issues requiring longer-term resolution. Issues and potential problems were brought to the forefront, not necessarily waiting for final resolution before reporting. It is better to err on the side of over-communicating; especially for issues whose outcome may affect cost or product quality.

NRPCT considers it a best practice to document these telecons and obtain vendor (e.g., national lab) concurrence with them. This was accomplished using the following process:

- Management conference call attendees included the project manager, project engineers and the Space Program Office Control Account representative.

- Space Program Office Control Account representative would draft conference call meeting minutes immediately after the call.

- Minutes would be reviewed by cognizant technical leads.

- Minutes, still considered "draft," would be transmitted for vendor review, comments and concurrence.

- Vendor comments would be provided by returning a "marked-up" copy via fax.

- As appropriate, comments would be incorporated or discussed with the vendor and resolved.

- Conference call meeting minutes would be formally issued and made contractual via Information-to-Vendor.

\section{Communications with Overseas Vendors or Subcontractors}

Once contract actions begin, similar to the domestic situation discussed above, it is important to maintain continued open communication among stakeholders. Again, a weekly telecon is well advised, even with significant time differences involved. It is possible to establish a "bridge" to call into for conference calls which permit calling from locations other than one's office. A local corporate contact individual who can speak the native language of the country in contract with is a valuable asset to have present during these calls. Documentation of these calls in a similar manner to calls with national labs (as discussed above) was too overwhelming as language barriers, formalities, and time differences complicating the review cycle often resulted in Meeting Minutes from the previous week's call being issued just prior to the new call. Any contractual or action items discussed were documented between the entities and passed down via Information-to-Vendor. Although it would have been more costly in both time and money, it would have been beneficial to have all contract and technical documents written in both English and Japanese. Translation services are available in both the US and Japan.

\section{Periodic Meetings}

There is no substitute for periodic face-to-face meetings to review program progress, data, courses of action, issues, scheduler matter, equipment or facilities, and most importantly, personnel. This is best accomplished via a trip to the vendor or laboratory site. Budgetary 
planning processes should adequately allocate funds to support travel requirements to contractor sites for frequent, e.g., quarterly meetings. For long trips, it is also recommended that an adjustment day be included prior to the meeting to better acclimate to drastic time (i.e., 12-13 hour) differentials. Adequate time on site should also be budgeted for meetings as well as facility tours. Again, formalized documentation processes should be employed including issuing trip reports by contractual methods.

\section{Travel Details}

For overseas trips to Japan, a translator was found to be helpful for contractual details, quality discussions, and meeting wrap-ups. English was generally spoken during technical meetings and went well without a translator. When off site, English speaking individuals were not always readily available. When traveling to JAEA, there is a Tourist Information Center in Terminal 2 at the Airport that can provide language assistance and other information (Tel: 0476-34-6251). There is a nationwide telephone service to aid in language and travel assistance (Tel: toll free0088-22-4800 outside of Tokyo/Kyoto and within Tokyo or Kyoto, dial 3201-3331 or 371-5649, respectively). An international phone card can be purchased before leaving the US. Appropriate card access numbers and specific directions for calling the US from Japan can be obtained from the card supplier. The country code for the USA is 1 (a single digit). Assistance using an 800 type number from Japan is not available.

The Japanese culture is extremely polite and not understanding and practicing Japanese etiquette during a business meeting could jeopardize relationships. As such, prior to meeting or interacting with Japanese individuals, one should familiarize themselves with Japanese etiquette. An excellent source for understanding both business and personal customs is the Reference (i), "Etiquette Guide to Japan".

\section{Concurrences}

This document has been reviewed and concurred to by the Managers of KAPL- Space Materials Testing and Bettis- Space Materials Irradiation.

Prepared by:

Michael Lane, Principal Engineer

Space Materials Irradiation Testing

Materials Development Operation

Approved by:

George Newsome, Manager

KAPL-Space Materials Irradiation Testing Materials Development Operation
William S. Saylor, Manager

Bettis- Space Materials Irradiation

Materials Technology 


\section{References:}

(a) MDO-723-0011/B-MT(SRME) -53, "Refractory Metal Irradiation Testing at Oak Ridge National Laboratory," February 2006.

(b) DOE Acquisition Guidance Subchapter 70.10

(c) KAPL Letter MDO-723-0021/ Bettis Letter B-MT(SRME)-21, April 2005.

(d) MDO-723-0030/B-MT(EDT)S-015,"Revised NRPCT response to NR comments to the JOYO-1 Irradiation Test Recommendation," June 2005.

(e) B-MT(EDT)S-018, "JOYO-1 Design for Permission Report Presentations to JNC for Testing of Structural Materials in the JOYO Reactor," July 2005.

(f) MDO-723-0006/B-MT(EDT)S-005, "Request for Approval to: 1) Conduct Material Irradiation Testing in the JOYO Experimental Fast Reactor to Support Space Reactor Development and 2) Engage JAERI and JNC in Discussions Regarding Future Fuel Testing," December 2004.

(g) MDO-723-0044/B-MT(SRME)-52, "JOYO-1 Irradiation Test Campaign Technical Closeout, For Information.” January 2006.

(h) SM-7234-0010, "Review Status of JOYO-1 Project," November 2005.

(i) Boye De Mente, "Etiquette Guide to Japan," Tuttle Publishing, North Clarendon, VT, 1990.

\section{Attachments:}

[1] Public Utterance Clause

[2] Process for SMA Approvals / Agreements and Contracts for JOYO Testing

\section{Enclosures:}

[1] Summary of Candidate Reactor Facilities Feasibility Study for an Overseas High Fluence Irradiation Test, Ryan Nelson and Rebecca Northey.

[2] Space Reactor Materials Irradiation Testing Project Summary Report: "Irradiation of Advanced Structural Materials in JOYO to Support the Development of a Space Fission Reactor", PNNL Project 48552, Report \# PNNL-15610, Revision 1, April 2006.

[3] Application of Nuclear Hazard Indemnity Clause to the Irradiation of Space Reactor Materials in the JOYO Experiment Fast Reactor Project, Painter, CL. March 2005. 
MDO-723-0057

PAGE 16

This Page Intentionally Left Blank 
Attachment 1 to

MDO-723-0057

PAGE 1

Attachment 1:

Public Utterance Clause

PRE-DECISIONAL - For Planning and Discussion Purposes Only 
A. Information, data, photographs, sketches, advertising, displays, promotional brochures or other materials provided to either party (Publishing Party) by the other party or generated or prepared during and under this contract, which the Publishing Party desires to publish, display or release to other contractors, to government agencies, or to the public shall be submitted to the other party for comment and review. This information shall be submitted to the other party for comment and review as much prior to the desired printing or release dates as possible. The requirement for comment and review shall not apply to information provided by Battelle to U.S. Government or contractor activities for internal use in support of Project Prometheus and/or related projects. The requirement for comment and review shall also not apply to information that either party is required to furnish to its respective government under the terms of its operating contract, policy or agreement. Information sought through governmental authority other than as described above shall be treated in accordance with paragraph (B) of this clause.

Additionally, the Publishing Party shall not associate information, data, photographs, sketches, advertising, displays, promotional brochures or other materials with the other party, related work assignments, end users or projects in any publicly releasable documents without the prior written approval of the other party.

B. Should any information described above be requested, subpoenaed, or otherwise sought by a court of competent jurisdiction or other judicial, administrative or governmental authority from either party, this should be promptly brought to the attention of the other party to permit appropriate measures to be taken to protect the information. Under no circumstances should this information be released to such authority without prior notification of the other party.

C. Contractor agrees that this requirement of prior review and comment by the other party of any release desired by the Publishing Party shall survive the contract and that neither party shall for a period of twenty years subsequent to the issuance of the contract either directly or indirectly issue any such release without the requisite review and comment of the other party, its successor or assignee.

D. Contractor shall include all provisions of this article including this sentence in all lower-tier subcontracts under this Contract.

E. Notwithstanding the foregoing provisions of this clause, Contractor may make a public release in the form of Attachment A hereto.

\author{
End of Clause
}


Attachment 2 to

MDO-723-0057

PAGE 1

\author{
Attachment 2: \\ Process for SMA Approvals \\ Agreements and Contracts for JOYO Testing
}




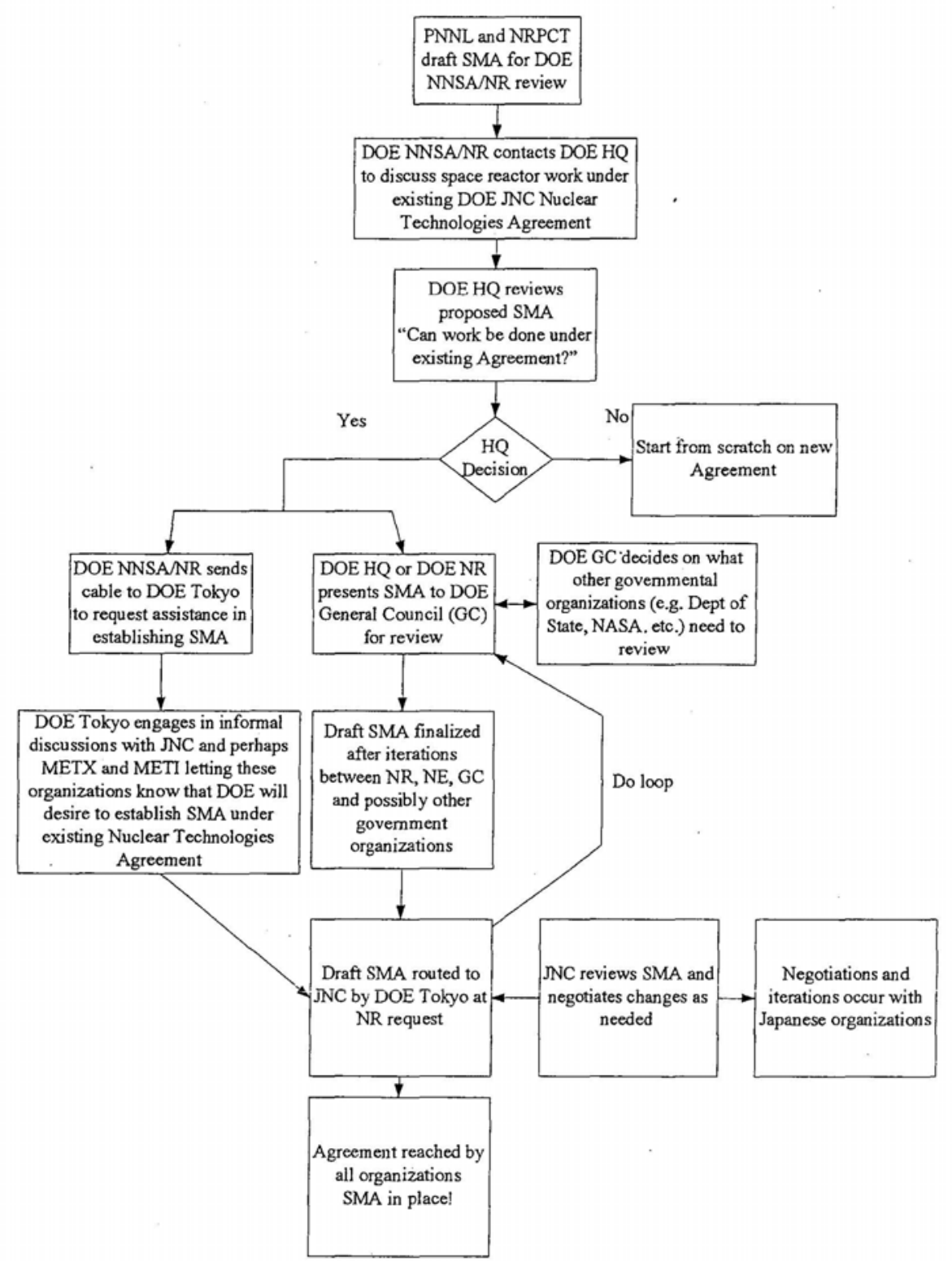

Figure 1. Process to Establish SMA with JNC to Establish "Peaceful Uses” 


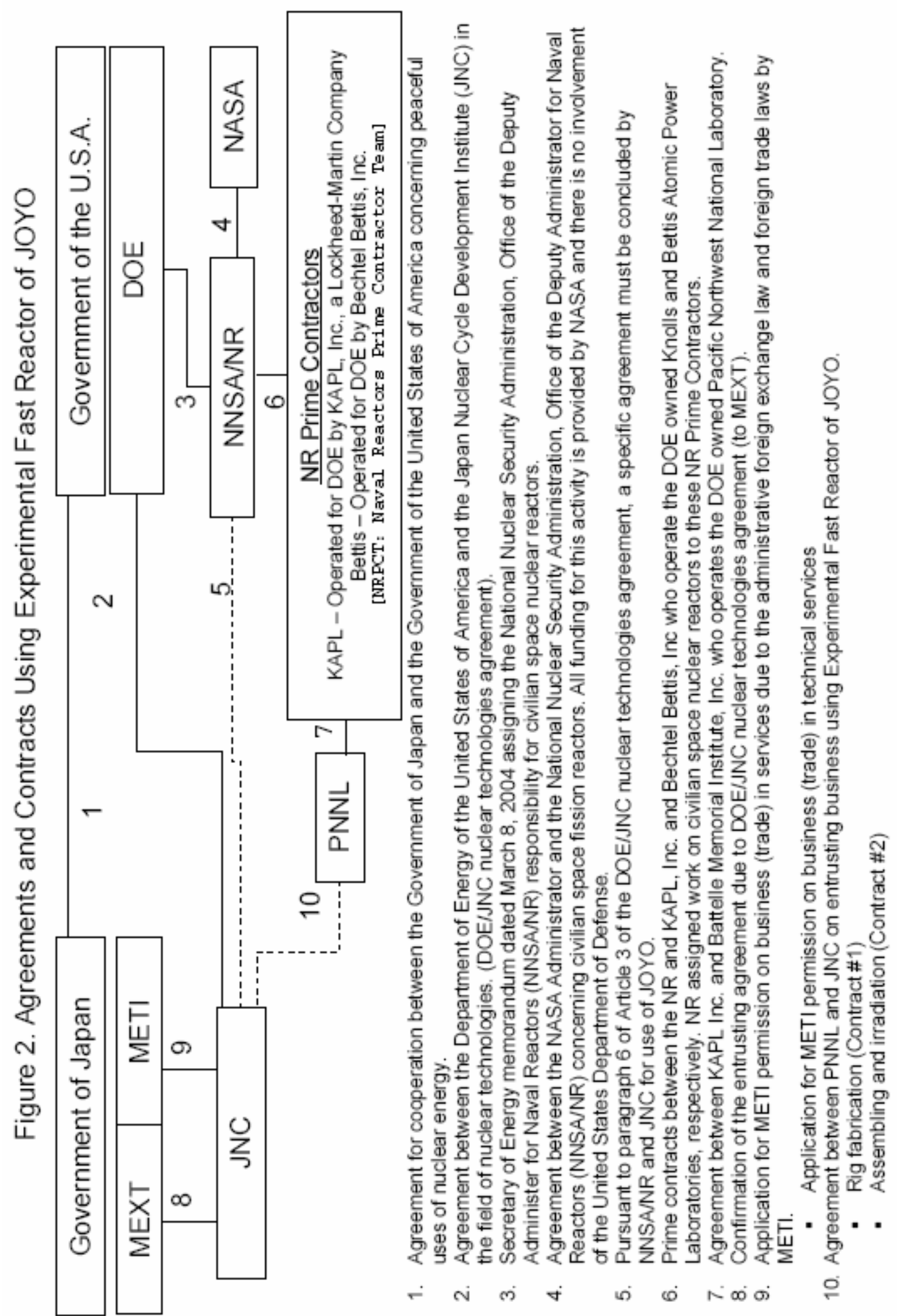


Attachment 2 to

MDO-723-0057

PAGE 4

This Page Intentionally Left Blank

PRE-DECISIONAL - For Planning and Discussion Purposes Only 
Enclosure 1 to

MDO-723-0057

PAGE 1

\author{
Enclosure 1 \\ Summary of Candidate Reactor Facilities Feasibility Study for \\ an Overseas High Fluence Irradiation Test \\ Ryan Nelson \\ Rebecca Northey
}

February 2006 


\section{Introduction}

Due to aggressive efforts to obtain irradiation data on fuel and structural materials, as well as subscale fuel elements, the Naval Reactors Prime Contractor Team (NRPCT) vigorously investigated irradiation test platforms to accomplish the testing required to support Project Prometheus. Fast reactors provide near prototypic neutron spectra that are needed to obtain irradiated material performance data to support material selection decisions for the Prometheus space reactor. Available data for candidate materials irradiated within Prometheus fast fluence range estimates are very limited, resulting in a large testing need to build a workable and statistically viable material database. To support this need, the NRPCT requested that Pacific Northwest National Laboratory (PNNL) perform a feasibility assessment for conducting a high fluence irradiation test in a foreign fast fluence test reactor (Reference 1).

Based on PNNL's feasibility assessment, the NRPCT concluded that the Experimental Fast Reactor JOYO was the best facility to initiate a large scale irradiation test to support Prometheus. Upon establishment of the JOYO-1 structural materials test matrix, the NRPCT understood that JOYO-1 testing alone would not satisfy all irradiation testing needs for a Prometheus reactor. Given limitations to the JOYO-1 test matrix due to availability of irradiation test space and large testing needs, NRPCT considered it vital to initiate parallel material testing as soon as possible. The NRPCT planned the additional structural tests, JOYO-2 and JOYO-3, for late 2007/early 2008 and 2010, respectively. Although it is desirable to test structural materials in a fast spectrum to obtain timely test results and avoid thermal transmutation effects, additional testing in the High Flux Isotope Reactor (HFIR) was planned for silicon carbide (SiC) materials, which do not transmutate in the presence of thermal irradiation. HFIR has a peak fast flux about half that of JOYO. However, testing of structural materials in HFIR requires insertion in the reduced flux "Removable Beryllium $\left(\mathrm{RB}^{*}\right)$ " region to minimize transmutation and thermal neutron effects through shielding. Due to the reduced flux in this region, achieving prototypical end-of-life (EOL) fluences would take about 10 times longer than testing in JOYO.

Comparatively, the test duration necessary to obtain a similar fluence in the Advanced Test Reactor (ATR) at Idaho National Laboratory (INL) is also a factor of ten longer, again due to a lower fast flux. Scheduler challenges with irradiation campaigns in the HFIR and ATR reactors were exacerbated by additional design complexity of overcoming unwanted thermal spectral effects, whereas commencing international fast reactor tests were challenging due to longer than expected test design, permitting /licensing and specimen/rig construction times.

\section{Fast Spectrum Reactors}

Currently, there are four operating fast research reactors and one (currently shut down) fast power reactor worldwide. In addition, there are several thermal research reactors that provide significant fast flux relevant for materials irradiation testing. Table 1 lists five overseas watermoderated research reactors, one overseas gas-cooled reactor, and two domestic thermal research reactors for comparison. Table 2 lists four operating overseas fast research reactors, one overseas fast power reactor and two decommissioned domestic fast research reactors. Although Monju is not currently operating or used as a research reactor, it has been included in Table 2 because the intention is to operate Monju as a research reactor if it receives restart approval. The peak fast flux and core volumes are included in Tables 1 and 2 to provide relative dose and size comparisons among the various reactors. For example, to a first approximation, irradiation test volume will be proportional to active core volume. It should be noted that the peak fast fluxes ( $E>0.1 \mathrm{MeV}$ in each case) listed in the tables correspond to operation at the rated power. Many of these reactors do not routinely operate at full power, so 
the maximum practical fast flux typically is lower than these values. Finally, two fast flux values are listed for the ATR; these indicate the peak fast flux at full power and the estimated peak fast flux if flux boosting technology is implemented in future irradiation tests. A preliminary feasibility assessment performed in September 2004 identified JOYO as the most promising candidate for both near and long-term irradiation testing based on both technical and logistical considerations. Detailed assessments of the JOYO, BOR-60, Fast Breeder Test Reactor, Monju, and Phénix Reactors are provided below.

Table 1. Candidate Overseas Thermal Reactors Along with U.S. Reactors for Comparison (Gas-Cooled Reactor Shaded)

\begin{tabular}{|c|c|c|c|c|}
\hline Reactor & Location & $\begin{array}{l}\text { Rated } \\
\text { Power } \\
(\mathbf{M W t})\end{array}$ & $\begin{array}{l}\text { Peak Fast Flux } \\
(1015 \mathrm{n} / \mathrm{cm} 2-\mathrm{s})\end{array}$ & $\begin{array}{c}\text { Core } \\
\text { Volume (l) }\end{array}$ \\
\hline SM & Russia & 100 & 2.0 & 48 \\
\hline Osiris & France & 40 & 0.26 & unknown \\
\hline Japan Materials Testing Reactor & Japan & 50 & 0.40 & 244 \\
\hline High Flux Reactor & Netherlands & 45 & 0.46 & 169 \\
\hline High Temperature Engineering Test Reactor & Japan & 30 & 0.02 & 8856 \\
\hline FRM-II & Germany & 20 & 0.50 & 18 \\
\hline $\begin{array}{ll}\begin{array}{l}\text { Advanced Test } \\
\text { Reactor }\end{array} & \text { (with fast flux } \\
\text { boosting) }\end{array}$ & USA & 250 & $0.20 \quad(0.50)$ & 275 \\
\hline High Flux Isotope Reactor & USA & 85 & 1.7 & 51 \\
\hline
\end{tabular}

Table 2. Candidate Overseas Fast Reactors Along with U.S. Reactors for Comparison

\begin{tabular}{||l|c|c|c|c||}
\hline \multicolumn{1}{|c|}{ Reactor } & Location & $\begin{array}{c}\text { Rated Power } \\
(\mathbf{M W t})\end{array}$ & $\begin{array}{c}\text { Peak Fast Flux } \\
(\mathbf{1 0 1 5} \text { n/cm2-s) }\end{array}$ & $\begin{array}{c}\text { Core } \\
\text { Volume (l) }\end{array}$ \\
\hline Monju & Japan & 714 & 6.0 & 2340 \\
\hline Phénix & France & 563 & 7.2 & 1227 \\
\hline Joyo (Mk III) & Japan & 140 & 4.0 & 227 \\
\hline BOR-60 & Russia & 60 & 3.5 & 60 \\
\hline Fast Breeder Test Reactor & India & 17.4 & 1.4 & 24 \\
\hline Fast Flux Test Facility (FFTF) & USA & 400 & 7.2 & 1040 \\
\hline $\begin{array}{l}\text { Experimental Breeder Reactor II } \\
\text { (EBRII) }\end{array}$ & USA & 62.5 & 2.5 & 73 \\
\hline
\end{tabular}

\section{JOYO}

JOYO is part of the O-arai Engineering Center (OEC), operated by the Japan Atomic Energy Agency (JAEA), a government-owned corporation, located in O-arai, Japan. JAEA reports to two government agencies, the Ministry of Education, Culture, Sports, Science and Technology (MEXT) and the Ministry of Economy, Trade and Industry (METI). JOYO achieved initial criticality in 1977 and began full-power operation (at that time $75 \mathrm{MW}_{\mathrm{t}}$ ) in 1979. It was built as a test reactor to support Japanese fast breeder reactor fuels and materials development. However, it also has been used by a variety of foreign customers from Europe and the US for irradiation testing. JOYO was recently upgraded to bring the core to its present Mk-III configuration, which increased the flux and volume available for irradiation testing. In terms of size and fast flux, JOYO is intermediate to EBR-II and FFTF (Table 2). The Mk-III upgrade included an increase in rated power from 100 to $140 \mathrm{MW}_{\mathrm{t}}$, an increase in the peak fast flux from 
3.2 to $4.0 \times 10^{15} \mathrm{n} / \mathrm{cm}^{2}-\mathrm{s}$, and an increase in the maximum number of irradiation testing locations from 9 to 21 (15 of which are in the core and reflector regions).

\section{Irradiation Testing Capabilities}

JOYO is a loop-type sodium-cooled Liquid Metal Reactor (LMR) that utilizes a Mixed Oxide Fuel (MOX). The reactor operating cycle is 60 effective full power days (EFPD), with approximately 20 days between cycles for refueling and experiment handling. A nominal operating schedule includes five cycles per year followed by approximately six to twelve months of down time for inspections and maintenance, although in practice the operation schedule varies frequently.

The Mk-III JOYO core configuration includes several different core locations designated for different irradiation vehicles. Instrumented test assemblies are described in Table 3 and uninstrumented test vehicles are described in Table 4. The JOYO-1 specimens were to be located in the reflector region, not the core region, which lowers available irradiation flux. Although positioning within the core region was desirable, licensing restrictions caused JOYO-1 to shift to the reflector. Additional testing for JOYO-2 and JOYO-3 would have targeted irradiation in the core region.

Table 3: Summary of JOYO instrumented irradiation vehicle capabilities.

\begin{tabular}{|c|c|}
\hline $\begin{array}{l}\text { Irradiation } \\
\text { Vehicle }\end{array}$ & Capabilities \\
\hline $\begin{array}{l}\text { Material Testing } \\
\text { Rig with } \\
\text { Temperature } \\
\text { Control } \\
\text { (MARICO-1) }\end{array}$ & $\begin{array}{l}\text { MARICO-1 provides real time temperature monitoring and control }\left( \pm 4^{\circ} \mathrm{C}\right) \\
\text { through He/Ar gas mixing or electric heaters. Double-wall capsules contain } \\
\text { materials specimens. MARICO- } 1 \text { holds } 3 \text { capsules at each of } 5 \text { axial } \\
\text { positions in the core. Irradiation space within each capsule is } 23 \mathrm{~mm} \text { in } \\
\text { diameter ( } 17 \mathrm{~mm} \text { in diameter with electric heaters) and } 75 \mathrm{~mm} \text { long. One } \\
\text { designated location on the outer edge of inner core in Row } 3 \text { (position } 3 \mathrm{E} 3) \text {, } \\
\text { mid-plane fast flux is } 3.55 \times 10^{15} \mathrm{n} / \mathrm{cm}^{2}-\mathrm{s}(\mathrm{E}>0.1 \mathrm{MeV}) \text {. MARICO-1 may be } \\
\text { disassembled for interim examination and reconstituted for further irradiation. }\end{array}$ \\
\hline MARICO-2 & $\begin{array}{l}\text { Upgraded MARICO 1. Electric heater capsule 2. Enlarged irradiation volume } \\
\text { 3. Increased temperature range }\left(405^{\circ} \mathrm{C} \text { to } 750^{\circ} \mathrm{C}\right) 4 \text {. MARICO-2 may be } \\
\text { disassembled for interim examination and reconstituted for further irradiation. }\end{array}$ \\
\hline $\begin{array}{l}\text { Instrumented } \\
\text { Test Assembly } \\
\text { (INTA) }\end{array}$ & $\begin{array}{l}\text { INTA monitors real-time irradiation data from complete fuel pins including fuel } \\
\text { temperature, fission gas pressure, and coolant flow rate. Data are available } \\
\text { in real-time during the irradiation test. INTA is interchangeable with MARICO } \\
\text { in position 3E3. }\end{array}$ \\
\hline $\begin{array}{l}\text { Upper Core } \\
\text { Structural } \\
\text { Irradiation Plug } \\
\text { Rig } \\
\text { (UPR) }\end{array}$ & $\begin{array}{l}\text { UPR is located in the reflector region above the core. Sample temperatures } \\
\text { are maintained between } 500^{\circ} \mathrm{C} \text { and } 700^{\circ} \mathrm{C} \text { with electrical heaters and } \\
\text { temperature is monitored continuously. One designated location on the outer } \\
\text { edge of inner core in Row } 3 \text { opposite MARICO (position 3B3). Up to } 60 \\
\text { standard-sized tensile samples can be irradiated in the UPR. The fast flux } \\
\text { above the core is } 6.4 \times 10^{10} \mathrm{n} / \mathrm{cm}^{2}-\mathrm{s}(\mathrm{E}>0.1 \mathrm{MeV}) \text {. }\end{array}$ \\
\hline $\begin{array}{l}\text { Ex-vessel } \\
\text { Irradiation Rig } \\
\text { (EXIR) }\end{array}$ & $\begin{array}{l}\text { EXIR is located outside the core in the space between the reactor guard } \\
\text { vessel and safety vessel. Sample temperatures are maintained between } \\
200^{\circ} \mathrm{C} \text { and } 600^{\circ} \mathrm{C} \text { with electrical heaters. Temperature is monitored } \\
\text { continuously, tensile stresses can be applied to samples in-situ via gas } \\
\text { pressure, and strain can be monitored in-situ. Up to } 6 \text { standard-sized tensile } \\
\text { samples can be irradiated in the EXIR. Fast flux immediately outside the } \\
\text { vessel is } 1 \times 10^{10} \mathrm{n} / \mathrm{cm}^{2}-\mathrm{s}(\mathrm{E}>0.1 \mathrm{MeV}) \text {. }\end{array}$ \\
\hline
\end{tabular}


Table 4: Summary of JOYO uninstrumented irradiation vehicle capabilities.

\begin{tabular}{|c|c|}
\hline Irradiation Vehicle & Capabilities \\
\hline $\begin{array}{l}\text { Uninstrumented Irradiation } \\
\text { Subassembly - Type A } \\
\text { (UNIS-A) }\end{array}$ & $\begin{array}{l}\text { Experimental fuel pins arranged within driver fuel pins. Two } \\
\text { designated locations in the outer core in Row } 4 \text {, mid-plane fast } \\
\text { flux is } 3.4 \times 10^{15} \mathrm{n} / \mathrm{cm}^{2}-\mathrm{s}(\mathrm{E}>0.1 \mathrm{MeV}) \text {. UNIS-A may be } \\
\text { disassembled for interim examination and reconstituted for } \\
\text { further irradiation. }\end{array}$ \\
\hline $\begin{array}{l}\text { Uninstrumented Irradiation } \\
\text { Subassembly - Type B } \\
\text { (UNIS-B) }\end{array}$ & $\begin{array}{l}\text { Six compartments of } 5 \text { fuel pins. Coolant flow rate in each } \\
\text { compartment can be controlled separately. One designated } \\
\text { location in the inner core in Row } 1 \text {, mid-plane fast flux is } 4.0 \mathrm{x} \\
10^{15} \mathrm{n} / \mathrm{cm}^{2}-\mathrm{s}(\mathrm{E}>0.1 \mathrm{MeV}) \text {. UNIS-B may be disassembled for } \\
\text { interim examination and reconstituted for further irradiation. }\end{array}$ \\
\hline $\begin{array}{l}\text { Uninstrumented Irradiation } \\
\text { Subassembly - Type C } \\
\text { (UNIS-C) }\end{array}$ & $\begin{array}{l}\text { Performance testing of fuel pin bundles, including bundles with } \\
\text { variable diameters. Two designated locations in the outer core } \\
\text { in Row } 4 \text {, mid-plane fast flux is } 3.4 \times 10^{15} \mathrm{n} / \mathrm{cm}^{2}-\mathrm{s}(\mathrm{E}>0.1 \\
\mathrm{MeV}) \text {. UNIS-C may be disassembled for interim examination } \\
\text { and reconstituted for further irradiation. }\end{array}$ \\
\hline $\begin{array}{l}\text { Uninstrumented Irradiation } \\
\text { Subassembly - Type D } \\
\text { (UNIS-D) }\end{array}$ & $\begin{array}{l}\text { Modification to UNIS-B with } 18 \text { compartments that each hold } \\
\text { one shorter irradiation test pin. Two designated locations in } \\
\text { the inner core in Row } 1 \text {, mid-plane fast flux is } 4.0 \times 10^{15} \mathrm{n} / \mathrm{cm}^{2}- \\
\mathrm{s}(\mathrm{E}>0.1 \mathrm{MeV}) \text {. UNIS-D may be disassembled for interim } \\
\text { examination and reconstituted for further irradiation. }\end{array}$ \\
\hline $\begin{array}{l}\text { Core Materials Irradiation } \\
\text { Rig } \\
(\mathrm{CMIR})\end{array}$ & $\begin{array}{l}\text { Seven compartments in which a variety of core material } \\
\text { specimens are encapsulated. Specimen temperatures are } \\
\text { maintained using a fixed gas gap with an accuracy of } \pm 10^{\circ} \mathrm{C} \text {. } \\
\text { One designated location in the inner core in Row } 0 \text {, mid-plane } \\
\text { fast flux is } 4.0 \times 10^{15} \mathrm{n} / \mathrm{cm}^{2}-\mathrm{s}(\mathrm{E}>0.1 \mathrm{MeV}) \text {. CMIR may be } \\
\text { disassembled for interim examination and reconstituted for } \\
\text { further irradiation. }\end{array}$ \\
\hline $\begin{array}{l}\text { Structural Materials } \\
\text { Irradiation Rig } \\
\text { (SMIR) }\end{array}$ & $\begin{array}{l}\text { Same as CMIR for structural materials. Four designated } \\
\text { locations in the reflector in Row } 7, \text { mid-plane fast flux is } \\
\text { approximately } 2 \times 10^{15} \mathrm{n} / \mathrm{cm}^{2}-\mathrm{s}(\mathrm{E}>0.1 \mathrm{MeV}) \text {. SMIR may be } \\
\text { disassembled for interim examination and reconstituted for } \\
\text { further irradiation. }\end{array}$ \\
\hline $\begin{array}{l}\text { Absorber Materials } \\
\text { Irradiation Rig } \\
\text { (AMIR) }\end{array}$ & $\begin{array}{l}\text { Same as CMIR for absorber materials. Two designated } \\
\text { locations in the reflector in Row } 7 \text {, mid-plane fast flux is } \\
\text { approximately } 2 \times 10^{15} \mathrm{n} / \mathrm{cm}^{2}-\mathrm{s}(E>0.1 \mathrm{MeV}) \text {. AMIR may be } \\
\text { disassembled for interim examination and reconstituted for } \\
\text { further irradiation. }\end{array}$ \\
\hline
\end{tabular}




\section{Irradiation Testing and Reactor Operational Experience}

JOYO is operated by the Experimental Reactor Division, within the Irradiation Center of OEC. Irradiation experiment planning, design and analysis are the responsibility of the Irradiation and Administration Section within the Irradiation Center. A significant number of irradiation experiments have been conducted in JOYO, and a vigorous testing program is expected to continue. Most testing has been associated with Japanese LMR fuel and cladding development, but there have been, and continue to be a number of other programs utilizing JOYO and its associated hot cell facilities. Although most of JOYO's customers are domestic (Japanese), JAEA personnel have experience conducting joint irradiation studies with foreign partners, such as France and the US.

\section{Post-Irradiation Examination and Testing Capabilities}

There are three hot cell facilities at OEC, operated by the Fuels and Materials Division within the Irradiation Center. These hot cells include the Fuels Monitoring Facility (FMF), the AlphaGamma Facility (AGF), and the Material Monitoring Facility (MMF).

The FMF (divided into two sections, Table 5) is responsible for receipt of assemblies from JOYO, cleaning, x-ray radiography, disassembly, non-destructive examination of assemblies and disassembled pins, and preparation of samples for further examination and testing in the AGF and MMF.

Table 5: Breakdown of the hot cells of FMF

\begin{tabular}{|c|c|c|c|}
\hline \multicolumn{2}{|c|}{ FMF-1 (JOYO Fuel PIE) } & \multicolumn{2}{|c|}{ FMF-2 (Monju Fuel PIE) } \\
\hline $\begin{array}{c}\text { Examination Cell } \\
\text { Max y activity } \\
\text { limit: } 1.6 \mathrm{MCi}\end{array}$ & X-ray radiography & $\begin{array}{c}\text { Examination Cell } \\
\mathrm{N}_{2} \text { atmosphere } \\
\text { Max } \mathrm{Y} \text { activity limit: } \\
\mathrm{N}_{2} \text { atmosphere }\end{array}$ & $\begin{array}{c}\text { x-ray computed } \\
\text { tomography (CT) } \\
\text { (radial resolution of } \\
\pm 0.1 \mathrm{~mm} \text { ) }\end{array}$ \\
\hline $\begin{array}{c}\text { Metallography } \\
\text { Cell }\end{array}$ & $\begin{array}{c}\text { metallographic sample } \\
\text { preparation, optical and } \\
\text { Max y activity }\end{array}$ & & \\
limit: $300 \mathrm{Ci}$ & microscopyng electron & Decontamination cell & \\
$\mathrm{N}_{2}$ atmosphere & microprobe analysis & Air atmosphere & $* * * *$ \\
& secondary ion mass & & \\
& spectrometer (SIMS) & & \\
\hline
\end{tabular}

If irradiated materials were to be returned to the US from OEC, the FMF would prepare the shipment. For previous shipments of spent fuel from OEC to FFTF (Hanford, WA), JAEA used an International Atomic Energy Agency (IAEA) certified TN6-4 cask. Use of this cask (and others) was being evaluated by the NRPCT for performing this shipment (Reference 2). For PIE considerations within Japan, it should be noted that irradiated material shipments are routinely handled (e.g. between OEC and JAEA, O-arai, or to Tokai facilities).

The AGF performs non-destructive and destructive tests on fuel pins. Activities performed in AGF include sample preparation, optical microscopic examination of fuel pins, burn-up determination using mass spectroscopy, fission gas analysis, $x$-ray diffraction analysis, and melting point measurements $\left(2000-2900^{\circ} \mathrm{C}\right)$. With only a minimal amount of advanced fuels research currently underway, the majority of work at AGF is dedicated to fabrication of minoractinide-containing MOX fuel for advanced recycle applications. 
The MMF is responsible for microscopy and material properties testing of irradiated non-fuel materials. Hot cell operations include mechanical property testing (uniaxial creep, biaxial creep, static and transient burst, tensile, Charpy, creep-fatigue), thermophysical property testing (metrology, density, thermal expansion, thermal diffusivity, gas analysis), optical microscopy, and transmission electron microscope (TEM) sample preparation and examination which is equipped with energy dispersive spectroscopy (EDS) and electron energy loss spectroscopy (EELS) instrumentation. Historically, a majority of structural materials testing has been oriented toward stainless steel LMR cladding alloys. Accordingly, upper temperature limits for the majority of the MMF furnaces is $800-850^{\circ} \mathrm{C}$, while most operate in air.

Japan and the US currently have in place a bi-lateral agreement under Section 123 of the Atomic Energy Act, allowing safeguarded exchange of commercial nuclear power technology and nuclear materials. This agreement also allows for a limited exchange of classified information with US Department of State (DOS) approval, but may require a separate codicil to test future fuel systems, and take as much as two years to enact.

\section{BOR-60}

An alternative fast spectrum reactor to supplement JOYO was BOR-60, located at the Research Institute for Atomic Reactors (RIAR) on the Volga River about $900 \mathrm{~km}$ south east of Moscow, Russia. BOR-60, a $60 \mathrm{MW}_{\mathrm{t}} / 12 \mathrm{MW}_{\mathrm{e}}$ loop-type sodium-cooled LMR, was considered for additional structural material testing required for Prometheus. Like JOYO, BOR-60 offers a similar spectrum in the prototypical fast flux region. Peak fast flux at BOR-60's rated full power of $60 \mathrm{MW}_{\mathrm{t}}$ is $3.3 \times 10^{15} \mathrm{n} / \mathrm{cm}^{2}$-s; however, it typically operates at about $52 \mathrm{MW}_{\mathrm{t}}$, resulting in an effective peak fast flux of $2.85 \times 10^{15} \mathrm{n} / \mathrm{cm}^{2}$-s in the core region. In comparison, JOYO is a 140 $\mathrm{MW}_{\mathrm{t}}$ reactor with a peak fast flux of $4.0 \times 10^{15} \mathrm{n} / \mathrm{cm}^{2}$-s in-core and $1.9 \times 10^{15} \mathrm{n} / \mathrm{cm}^{2}-\mathrm{s}$ in the reflector region.

BOR-60 operates at power for five 50-day cycles (fast fluence of $64.8-112.3 \times 10^{20} \mathrm{n} / \mathrm{cm}^{2}$ accumulated per cycle) throughout one operating year with scheduled refueling shut-downs, whereas JOYO typically operates at power for five 60-day cycles over one calendar year. If the NRPCT were to conduct a test at BOR-60, the higher fast flux within the core region may have been utilized.

The BOR-60 reactor has the benefit of achieving the high end-of-life fast fluence expected in Prometheus within approximately 100 days, although volumes of the irradiation rigs are not as large as JOYO ( four BOR-60 rigs to each JOYO rig).

Previous US research experience lead to concern over quality assurance (QA) program conditions at BOR-60 for both irradiation testing and PIE. Further investigation alleviated this concern by finding that, while examination and testing capabilities are not state-of-the-art, (RIAR, like many Russian institutions, is capital-limited) most PIE data produced at RIAR is of very high quality. In addition, until the late 1990s, BOR-60 did not have a recognizable quality assurance program that would be acceptable to Western regulatory authorities. French researchers were instrumental in introducing structured quality assurance to BOR-60, and US researchers with recent experience at BOR-60 suggest that concerns regarding the existence of a QA program have been lessened in recent years. Until a pre-award survey can be conducted relative to the Quality Assurance Program Requirements for Nuclear Facilities (NQA-1), more definitive statements regarding the current state of the BOR-60 QA program cannot be made. 
Shipping between the US and Russia has also been problematic, with Western European countries typically serving as a go-between to facilitate shipments of fuels and structural materials. Also, irradiated materials were not always tested or returned in a timely fashion during past programs, causing significant scheduling difficulties. However, shipping arrangements have stabilized in recent years as regulatory environments in Russia have improved following the Soviet Union breakup.

If testing at BOR-60 were to proceed, it may have been facilitated by use of a long-existing business relationship between PNNL (Garner) and RIAR. A similar relationship did not exist with JAEA, where cooperative (US/Japanese) agreements rather than business agreements (contracts) have been historical practice. Based on positive feedback from both PNNL and RIAR, the next step in evaluating BOR-60 would have been to visit the reactor facility and obtain details needed to plan irradiation tests for structural materials.

\section{Fast Breeder Test Reactor}

The Fast Breeder Test Reactor (FBTR), located at the Indira Ghandi Centre for Atomic Research (IGCAR), Kalpakkam, India, achieved initial criticality in 1985, and has been operating in its current configuration since 1997. The FBTR is a loop-type sodium-cooled fast breeder reactor that utilizes mixed carbide $\left(\mathrm{UC}_{2} / \mathrm{PuC}\right)$ fuel. The reactor has been used extensively by Indian researchers for irradiation test campaigns, including a variety of fuels (carbide, oxide, and nitride), core structural materials (austenitic stainless steels as well as ferritic/martensitic steels), and zircaloy (for heavy water reactor pressure tube applications). However, FBTR has not been used as an irradiation testing platform by foreign customers due to export control issues. Hot cell facilities at IGCAR are quite extensive and include all standard fuel and structural materials testing and examination capabilities.

At a full-power level, FBTR is limited to approximately $12 \mathrm{MW}_{\mathrm{t}}$, thereby providing an available peak fast flux peak of $1 \times 10^{15} \mathrm{n} / \mathrm{cm}^{2}$-s. Because of this, FBTR may not be an attractive facility for irradiation of fuels or materials requiring a significant fast fluence. In addition, its small core size will limit available volume for irradiation experiments.

The US had very strict controls on export of potential dual-use nuclear-related materials and products to India. However, on September 17, 2004, the US and India issued a joint statement on the "Next Steps in a Strategic Partnership" that pledged increased cooperation in areas including civilian nuclear power and civilian space programs. At present, there are no details available for specific programs to be executed under this joint statement and lengthy negotiations will likely be required to define specific activities. The US has made modifications to export licensing policies that will foster cooperation in commercial space programs and permit certain exports to the balance-of-plant portion of Indian nuclear facilities, subject to IAEA safeguards. As such, fuel and core materials will still require significant export control restrictions. Also, according to the US DOE Office of Security, the US is prohibited by law from sending classified or sensitive, unclassified material to India. Although the possibility for conducting irradiation tests in India may be improving, it was premature to consider the FBTR as a viable near-term candidate for Prometheus testing.

\section{Monju}

Monju, located in Japan, is a sodium-cooled fast breeder reactor that utilizes a MOX fuel. It has a rated power of $714 \mathrm{MW}_{\mathrm{t}}$ and $280 \mathrm{MW}_{\mathrm{e}}$ and a design rod-average fuel burn-up of $80 \mathrm{GWd} / \mathrm{t}$. Monju has a peak fast flux of $6.0 \times 10^{15} \mathrm{n} / \mathrm{cm}^{2}$-s. This LMR employs three primary sodium loops, 
three secondary sodium loops, and a single water loop in which superheated steam generates electricity from a single turbine-generator. Surrounding the core is a radial breeder blanket comprised of 172 assemblies, with 61 pins per assembly.

Monju was originally intended as a power producer and achieved initial criticality in 1994 . During its run-up to full operation in 1995, it experienced a secondary-side sodium leak through a broken thermocouple well resulting in reactor shut down. The leaked sodium represented less than $0.1 \%$ of the secondary sodium volume, and resulting physical plant damage was quite minimal. The reactor has not operated since 1995, but has been maintained in hot standby condition.

Although numerous safety improvements have been proposed for Monju, they have not been implemented due to a "gentlemen's agreement" between JAEA and the government of Fukui Prefecture to not proceed until the local prefecture grants restart approval. After receiving local government approval to restart, Monju is expected to be used $s$ a test reactor and faces approximately 17 months of safety modifications, followed by two years of pre-operational testing. At this time, neither irradiation vehicles nor an irradiation testing infrastructure exist at Monju, and would have to be designed and licensed prior to use. JAEA has estimated lead times for these activities at 4-5 years.

From an irradiation testing perspective, the large core volume and high fast flux of Monju are attractive, and if restarted as a test reactor, JAEA is expected to replace the $\mathrm{UO}_{2}$ blanket fuel with a reflector region comprised of stainless steel pins, thus providing additional volume for specimens. Fuel and irradiation vehicle costs at Monju are expected to be correspondingly high relative to smaller reactors such as JOYO or BOR-60. At best, Monju was considered a possible long-range irradiation testing option.

\section{Phénix}

Phénix is a pool-type sodium-cooled fast reactor operated by the Commissariat à íÉnergie Atomique (CEA) in Marcoule, France, that utilizes MOX fuel. Phénix achieved first criticality in 1973, with full-power operations beginning in 1974. The mission of the Phénix reactor includes irradiation testing to support research for actinide burning and waste transmutation. The French government has passed a law limiting operation of Phénix until its present supply of fuel is exhausted. Accordingly, the reactor has a specified number of effective full-power days (EFPD) that remain in its operational lifetime. In general, Phénix will operate for approximately 240 EFPD per year (two 120 EFPD cycles), until its permanent shut down in 2007. The plant currently operates at a reduced power level of $320 \mathrm{MW}_{\mathrm{t}} / 142 \mathrm{MW}_{\mathrm{e}}$, corresponding to a peak fast flux range of 4.4 to $7.5 \times 10^{15} \mathrm{n} / \mathrm{cm}^{2}$-s. This reduced peak flux is still higher than all current operating fast reactors. Given appropriate approvals, classified fuels or materials may be irradiated in the Phénix fast reactor. A bilateral agreement is currently in place with US DOE and government agencies in France under Section 144 of the Atomic Energy Act (also known as a Mutual Defense Agreement, or MDA) defining acceptable classified activities or exchanges of classified materials between the US and France.

US researchers have conducted a number of experiments in Phénix. As a test reactor, it has many desirable attributes including high fast flux and a large test space. At present, there are approximately 30 experimental subassemblies located in various positions throughout the core and reflector region. Officially, Phénix is not accepting new experiments, but space may be available on an ad-hoc basis. Traditionally, Phénix personnel have performed the design, 
analysis, and fabrication of irradiation experiments. Experimenters are expected to provide only desired irradiation test parameters and at most, test specimens.

Post-Irradiation Examination (PIE) capabilities at Phénix are extensive, including neutron radiography, eddy current testing for cladding thickness measurements, all standard optical and electron microscopy techniques, energy dispersive x-ray spectroscopy, gamma spectroscopy, profilometry, metrology, fission gas analysis, and mechanical properties testing. If more specialized tests for irradiated materials are required, they can be accommodated either at the Phénix site in Marcoule or other CEA sites within France. Reconstitution of irradiation experiments is routinely performed.

Given the decommissioning schedule for Phénix, a long lead time for approval of new irradiation experiments, and experimental design and fabrication methods, the Phénix reactor was not considered a viable option for irradiation testing, despite its technical and possible logistical advantages.

\section{Water-Moderated High-Flux Test Reactors}

Several foreign water-moderated reactors were found to possess high fast flux for thermal research reactors (i.e., mixed spectrum), while most have good irradiation testing and PIE capabilities. However, none of the evaluated facilities possess capabilities that are particularly unique, and none offer a significant advantage over comparable domestic facilities. For example, the highest fast flux of the large, water-moderated overseas research reactors is FRMII in Germany $\left(0.5 \times 10^{15} \mathrm{n} / \mathrm{cm}^{2}\right.$-s), but its advantage over ATR is slight, when ATR is operated near full power $\left(0.2 \times 10^{15} \mathrm{n} / \mathrm{cm}^{2}\right.$-s) and/or with fast flux boosting technology implemented $(0.5 \mathrm{x}$ $10^{15} \mathrm{n} / \mathrm{cm}^{2}-\mathrm{s}$ ). Conclusions regarding other overseas thermal materials test reactors are similar as they all possess the same or lower fast flux as FRM-II. This includes the High Flux Reactor (HFR) in Petten, Netherlands $\left(0.46 \times 10^{15} \mathrm{n} / \mathrm{cm}^{2}-\mathrm{s}\right)$, the Japan Material Test Reactor (JMTR) in Japan $\left(0.40 \times 10^{15} \mathrm{n} / \mathrm{cm}^{2}-\mathrm{s}\right)$, and the Osiris reactor in France $\left(0.26 \times 10^{15} \mathrm{n} / \mathrm{cm}^{2}-\mathrm{s}\right)$. The SM reactor located at RIAR, Russia $\left(2.0 \times 10^{15} \mathrm{n} / \mathrm{cm}^{2}-\mathrm{s}\right)$ produces a high fast flux comparable to that of HFIR $\left(1.7 \times 10^{15} \mathrm{n} / \mathrm{cm}^{2}-\mathrm{s}\right)$, and both of these facilities offer essentially an order of magnitude higher fast flux than the other thermal research reactors, although at the expense of irradiation volume. The SM and HFIR core sizes are very similar, and both produce their high fast flux in a central flux trap. At locations external to the core, the fast flux of both SM and HFIR are very comparable to HFR, FRM-II, Osiris and JMTR. In terms of irradiation test capabilities, FRM-II and JMTR offer hydraulic rabbit facilities which allow for variable capsule exposure times without a reactor shutdown. SM has three self-contained water loops, and all overseas reactors have instrumented and uninstrumented capsule irradiation capabilities. However, none of these capabilities offer features that cannot be obtained at HFIR (e.g. rabbits) or ATR (e.g. loops). Therefore, NRPCT concluded that these reactors did not offer significant advantages over US reactors.

\section{High Temperature Engineering Test Reactor (HTTR)}

HTTR is a helium-cooled, graphite-moderated thermal reactor built to demonstrate gas reactor operational characteristics. HTTR is operated by JAEA and located in O-arai, Japan. It achieved initial criticality in 1998, with full-power operation starting in 2001 . The HTTR fuel is based on a TRISO particle with a $600 \mu \mathrm{m}$ diameter $\mathrm{UO}_{2}$ kernel surrounded by a porous pyrocarbon (PyC) buffer layer, a dense PyC layer, a SiC barrier, and an encapsulating dense PyC layer. The fuel particles are pressed into an annular graphite compact (39 mm long x 26 $\mathrm{mm}$ o.d. $\times 10 \mathrm{~mm}$ i.d.), and the compacts are stacked in a graphite sleeve to form a fuel rod, 
which is inserted into holes in a hexagonal graphite fuel assembly. The reactor core consists of 30 columns of fuel assemblies stacked 5 high. As with most gas-cooled reactors, core volume is very large relative to the rated power, resulting in a low power density that contributes to its passive safety. The fuel is limited to a maximum burn-up of $33 \mathrm{GWd} / \mathrm{t}$, with an average core burn-up of approximately $22 \mathrm{GWd} / \mathrm{t}$. This corresponds to approximately $660 \mathrm{EFPD}$ between refueling outages. The HTTR is currently operating with its initial core load of fuel.

HTTR is an attractive irradiation test platform because of the large core volume and high operating temperature. However, there has been no irradiation testing to date, although plans exist to perform future irradiation tests. There are limited hot cell facilities at HTTR, designed for handling, disassembly, and examination of spent fuel assemblies. It is expected that fuels or materials irradiated in HTTR would be taken to the JMTR Hot Laboratory (HL) located nearby on the O-arai site (not associated with JOYO). The JMTR-HL is physically connected to the JMTR reactor building by an underground canal used for transferring irradiated fuels and materials. In addition, irradiated fuels and materials also can be received in casks brought to the facility by trucks (e.g. from JOYO). In addition to the JMTR-HL at O-arai, JAEA has other hot cell facilities at Tokai (Reactor Fuel Examination Facility, RFEF) that may potentially be used.

\section{References}

1. MDO-723-0033 / B-MT(EDT)S-016, Forwarding of the "Feasibility Study for an Overseas High Fluence Irradiation Test in Support of Project Prometheus: Final Assessment of Candidate Reactor Facilities", June 2005.

2. MDO-723-0036 / B-MT(SRME)-37, "Overview of Domestic and International Shipping of Irradiated Materials and Handling Associated Waste”, January 2006. 
Enclosure 1 to

MDO-723-0057

PAGE 12

This Page Intentionally Left Blank

PRE-DECISIONAL - For Planning and Discussion Purposes Only 
Enclosure 2 to

MDO-723-0057

PAGE 1

\author{
Enclosure 2 \\ Space Reactor Materials Irradiation Testing Project \\ Irradiation of Advanced Structural Materials in JOYO to Support the Development \\ of a Space Fission Reactor \\ Dave Senor and Chad Painter \\ February 2006
}


Space Reactor Materials Irradiation Testing Project Summary Report

\section{Irradiation of Advanced Structural Materials in JOYO to Support the Development of a Space Fission Reactor}

Project 48552

D. J. Senor

C. L. Painter

April 2006

Revision 1

Prepared for the U.S. Department of Energy

under Contract DE-AC05-76RL01830

\section{LIMITED DISTRIBUTION}




\title{
DISCLAIMER
}

This report was prepared as an account of work sponsored by an agency of the United States Government. Neither the United States Government nor any agency thereof, nor Battelle Memorial Institute, nor any of their employees, makes any warranty, express or implied, or assumes any legal liability or responsibility for the accuracy, completeness, or usefulness of any information, apparatus, product, or process disclosed, or represents that its use would not infringe privately owned rights. Reference herein to any specific commercial product, process, or service by trade name, trademark, manufacturer, or otherwise does not necessarily constitute or imply its endorsement, recommendation, or favoring by the United States Government or any agency thereof, or Battelle Memorial Institute. The views and opinions of authors expressed herein do not necessarily state or reflect those of the United States Government or any agency thereof.

\author{
PACIFIC NORTHWEST NATIONAL LABORATORY \\ operated by \\ BATTELLE \\ for the \\ UNITED STATES DEPARTMENT OF ENERGY \\ under Contract DE-AC05-76RL01830
}

This document was printed on recycled paper.

$(9 / 2003)$ 
Space Reactor Materials Irradiation Testing Project Summary Report

\section{Irradiation of Advanced Structural Materials in JOYO to Support the Development of a Space Fission Reactor}

\section{Project 48552}

D. J. Senor

C. L. Painter

April 2006

Revision 1

Prepared for the U.S. Department of Energy under Contract DE-AC05-76RL01830

Pacific Northwest National Laboratory

Richland, Washington 99352 



\section{Summary}

Pacific Northwest National Laboratory staff utilized their expertise in welding, non-destructive test, material properties, reactor physics, international relations, and project management to coordinate a proposed irradiation of advanced structural materials in the JOYO experimental fast reactor. Advanced structural materials were to be irradiated as part of a space reactor development effort in support of NASA's Project Prometheus. The goal of Project Prometheus was to develop a space nuclear power plant which would significantly improve mankind's ability to conduct unmanned exploration of the Solar System. Funding for the Project Prometheus space reactor development effort was significantly reduced in September 2005 by NASA, after which the PNNL project was cancelled by the Naval Reactors Prime Contractor Team (NRPCT). This report summarizes PNNL's progress towards irradiating NRPCT supplied advanced structural materials in JOYO. 



\section{Contents}

Summary

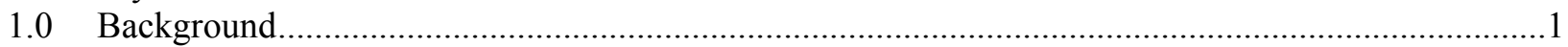

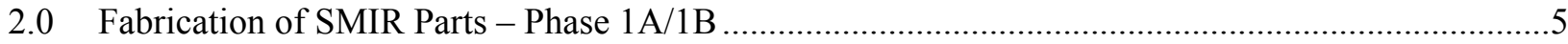

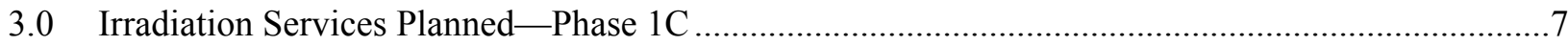

4.0 Long Lead Items to Support Future Irradiation Efforts-Phase 2A ...........................................11

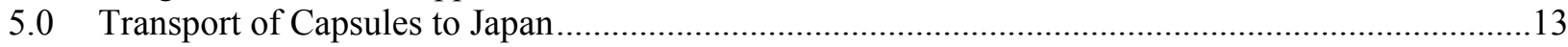

6.0 Shipment and Disposal of Radioactive Waste, Irradiated Capsules and Test Specimens .................17

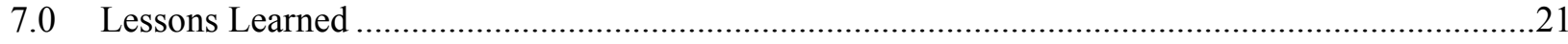

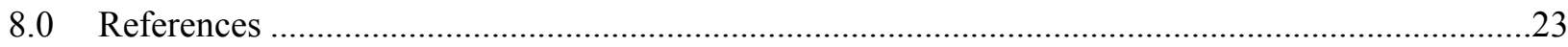

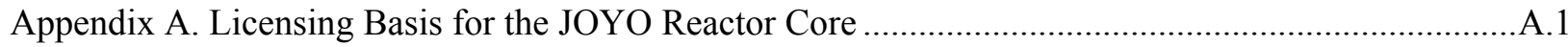

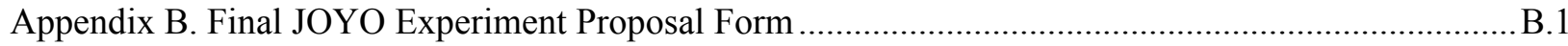

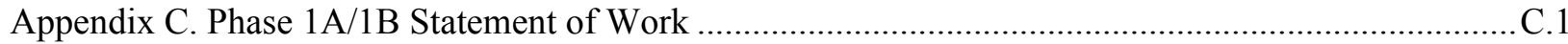

Appendix D. Agreement for Fabrication of Parts for Structural Materials Irradiation Rigs ....................D.1

Appendix E. Draft Statement of Work for Irradiation Services .......................................................... E.1

Appendix F. Draft Specific Memorandum Agreement .................................................................... F.1

Appendix G. Draft Statement of Work of Long Lead Items to Support Future Irradiation Efforts .............1

Appendix H. TN6-4 Cask Specifications ........................................................................................

\section{Figures}

Figure 1. Standard Schedule for Preparing Irradiation Experiments in JOYO .......................................2

Figure 2. Schedule for Proposed Structural Materials Irradiation Experiment .......................................... 3

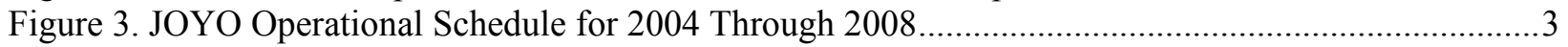

Figure 4. JOYO Irradiation Experiment Proposal Process .................................................................

Figure 5. Timeline for Purchase of Long Lead 316 Stainless Steel Billets ............................................11

Figure 6. Internals of Pelican Case for Shipment of Sealed Capsules......................................................13

\section{Tables}

Table 1. Phase 1A/1B Contract Deliverables, Deadlines, and Actual Completion Dates ............................5

Table 2. Estimate JAEA Contract Value for Irradiation Effort ...............................................................

Table 3. Upper Estimate of the Radioactivity from Both Rigs for Waste Disposal .................................. 18

Table 4. Shielded Waste Packages Required for the Materials in Both Rigs ............................................ 19

Table 5. Upper Estimate of the Radioactivity from Both Rigs for Transportation ................................... 19

Table 6. Upper Estimate of the Decay Heat from Both Rigs for Transportation .......................................19 



\subsection{Background}

Advanced structural materials were to be irradiated in the JOYO experimental fast reactor ${ }^{1}$ in Japan as part of an effort to test the behavior of such materials in a fast reactor environment. This irradiation test program was pursued in support of a space fission reactor development effort supporting NASA's Project Prometheus. Project Prometheus was to develop a nuclear powered space power plant which would greatly improve mankind's ability to explore the Solar System. The project was funded by Knolls Atomic Power Laboratory (KAPL) Inc. under Purchase Order FA01000076AE.

The JOYO reactor was selected as the best available facility to perform the irradiation given its inherent characteristics (Senor, et al. 2005). NASA's plans to develop a nuclear powered space power plant were cancelled in September 2005 when NASA and Naval Reactors agreed to terminate their partnership to develop a civilian space reactor. The termination of the program was a result of changing NASA priorities. This report presents a summary of PNNL's support to the Naval Reactor Prime Contractor Team (NRPCT) in managing the effort to irradiate advanced structural materials in JOYO. Management of the effort to irradiate advanced structural materials involved work in the following areas: development of international agreements, development of technical scopes of work, negotiations involving contract terms and conditions, indemnification language, transportation of specimens and irradiated materials, program planning, and waste issues. Under this project, PNNL was to assist in fabrication of the necessary biaxial creep specimens (by welding end caps) intended for irradiation. A separate report PNNL-15537, Biaxial Creep Specimen Electron Beam and Laser Seal Welding Demonstration Report was issued summarizing that effort.

Figure 1 presents the normal Japan Atomic Energy Agency (formerly the Japan Nuclear Cycle Development Institute) process for planning irradiation experiments in JOYO. Although the information exchange period is often much less than the 10-11 months shown on the schedule, most of the other time periods are reasonably representative. Normally, a contract for fabrication and irradiation services is finalized during the very early conceptual (basic) design phase, as shown in Figure 1. For an experiment in the core of the reactor, the materials and test conditions must fit within the existing licensing basis. The licensing basis for JOYO is shown in Appendix A. In general, the licensing basis is relatively narrow, mostly encompassing fuels and cladding materials for fast reactors. As a result, most experiments outside of the reactor licensing basis in the core will require something akin to a license amendment from the Ministry of Education, Culture, Sports, Science \& Technology (MEXT). While there is no specific list of prohibited materials, each experiment is considered on a case-by-case basis with regard to the licensing basis and safety impact. Applications for licensing approval typically are not filed until the conceptual design is complete. Detailed design and procurement of materials proceed in parallel with the licensing process. After licensing, the test specimens (fuel pins or individual samples) and irradiation vehicle fabrication activities begin. Finally, the irradiation vehicles are assembled and inserted into the reactor. Typical fuels experiments will require at least four years from starting the conceptual design to inserting the experiment in the reactor. The JOYO experimenter's handbook explains the irradiation testing design and analysis approach required for license amendment applications, but it is available only in Japanese.

\footnotetext{
${ }^{1}$ The JOYO reactor is located in O'arai, Japan, in the IBARAKI prefecture, which is northeast of Tokyo on the Pacific coast. The reactor is part of the O'arai Engineering Center (OEC). The JOYO reactor was operated by the Japan Nuclear Cycle Development Institute (JNC) until October 1, 2005 when JNC merged with the Japan Atomic Energy Research Institute (JAERI) to form the Japan Atomic Energy Agency (JAEA).
} 
After learning that the schedule shown in Figure 1 would not support Project Prometheus reactor development and that the primary interest was structural materials, JAEA staff agreed to produce a modified schedule to shorten the lead time. The resulting schedule is presented in Figure 2. This schedule was produced by incorporating the minimum time for each activity encountered in past experiments at JOYO. Fundamental assumptions used to produce this schedule included 1) structural materials only, 2) an uninstrumented irradiation vehicle, 3) irradiation in the JOYO reflector rather than the core, 4) availability of feedstock material for the irradiation vehicle, 5) NRPCT design of test specimens and capsules, and 6) contract award in early 2005. Later discussions suggested a willingness by JAEA to begin rig design and analysis work before contract award, with a target date of April 2005 for award of a rig parts fabrication contract and July 2005 for award of an irradiation services contract. The schedule shown in Figure 2 required that unsealed capsules and test specimens be delivered to JAEA by January 2006. The target cycle for experiment insertion was Mk-III core Cycle 5, beginning in June 2006. Cycle 5 was to be followed by a normal 20-day refueling outage before starting Cycle 6 . Cycle 6 is a bit unusual in that it includes full-power operation for about 5 days followed by a shut down of approximately 10 days to remove an irradiation experiment on minor actinide-containing MOX fuel. After the brief interruption, Cycle 6 will continue, with a planned completion date in November 2006. JOYO will be shut down throughout most of 2007 for maintenance and inspection, as shown in Figure 3. The reactor will return to normal operation with Cycle 7 starting in late 2007 and Cycle 11 ending in early 2009.

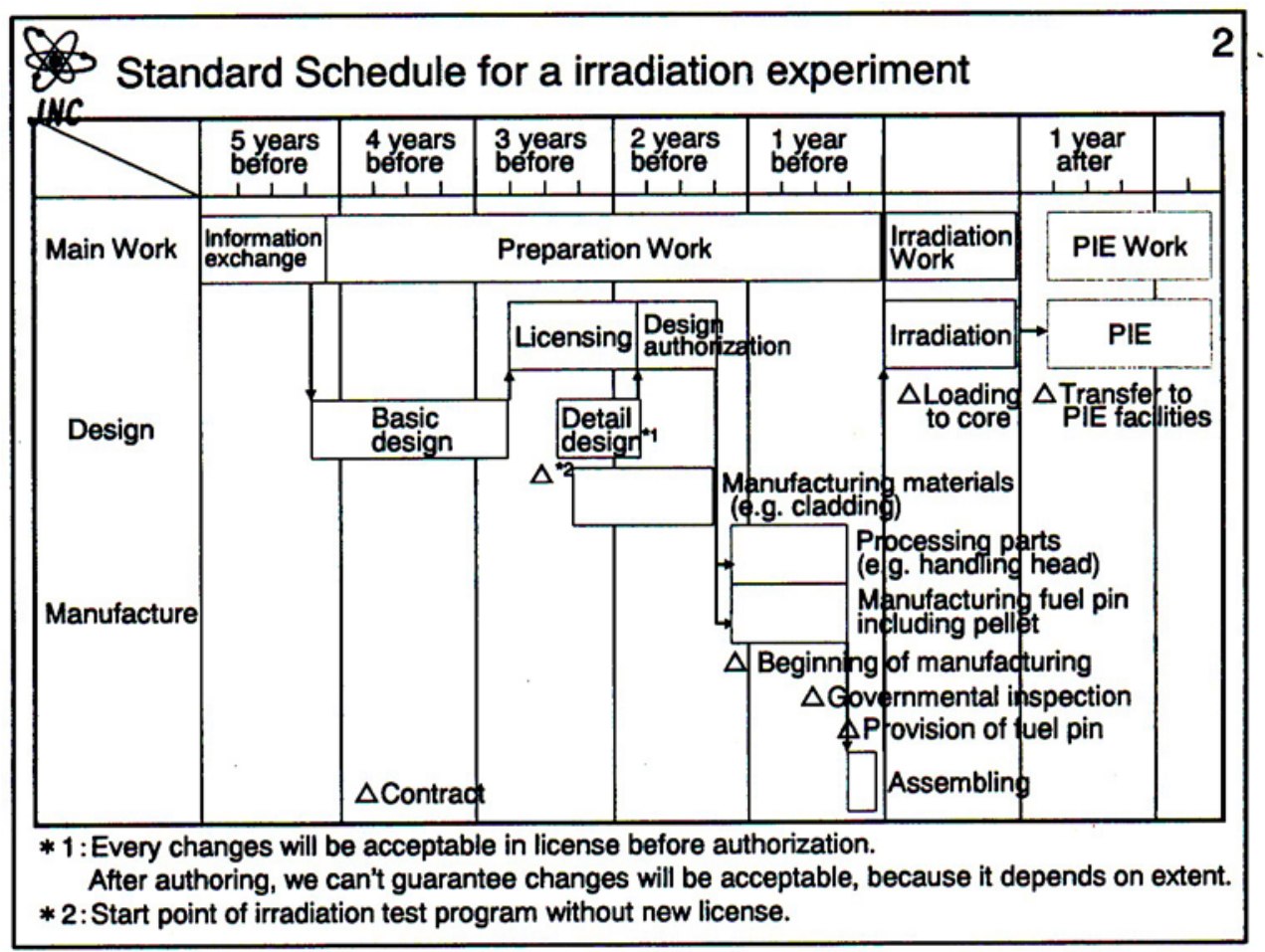

Figure 1. Standard Schedule for Preparing Irradiation Experiments in JOYO

To start the planning process for an irradiation experiment, the prospective customer must submit an experimental proposal form to JAEA. The proposal is to be routed through Oarai and corporate headquarters for approval in the manner shown in Figure 4. For the proposed Project Prometheus experiment, the proposal was submitted to JAEA by PNNL in July 2005 after receiving input from NRPCT and after several iterations with JAEA on draft proposals. The project was cancelled in 
September 2005, before the proposal was formally approved by JAEA corporate management. A copy of the proposal submitted to JAEA by PNNL is included in Appendix B.

\section{Tentative Schedule for Space Reactor Materials Irradiation}

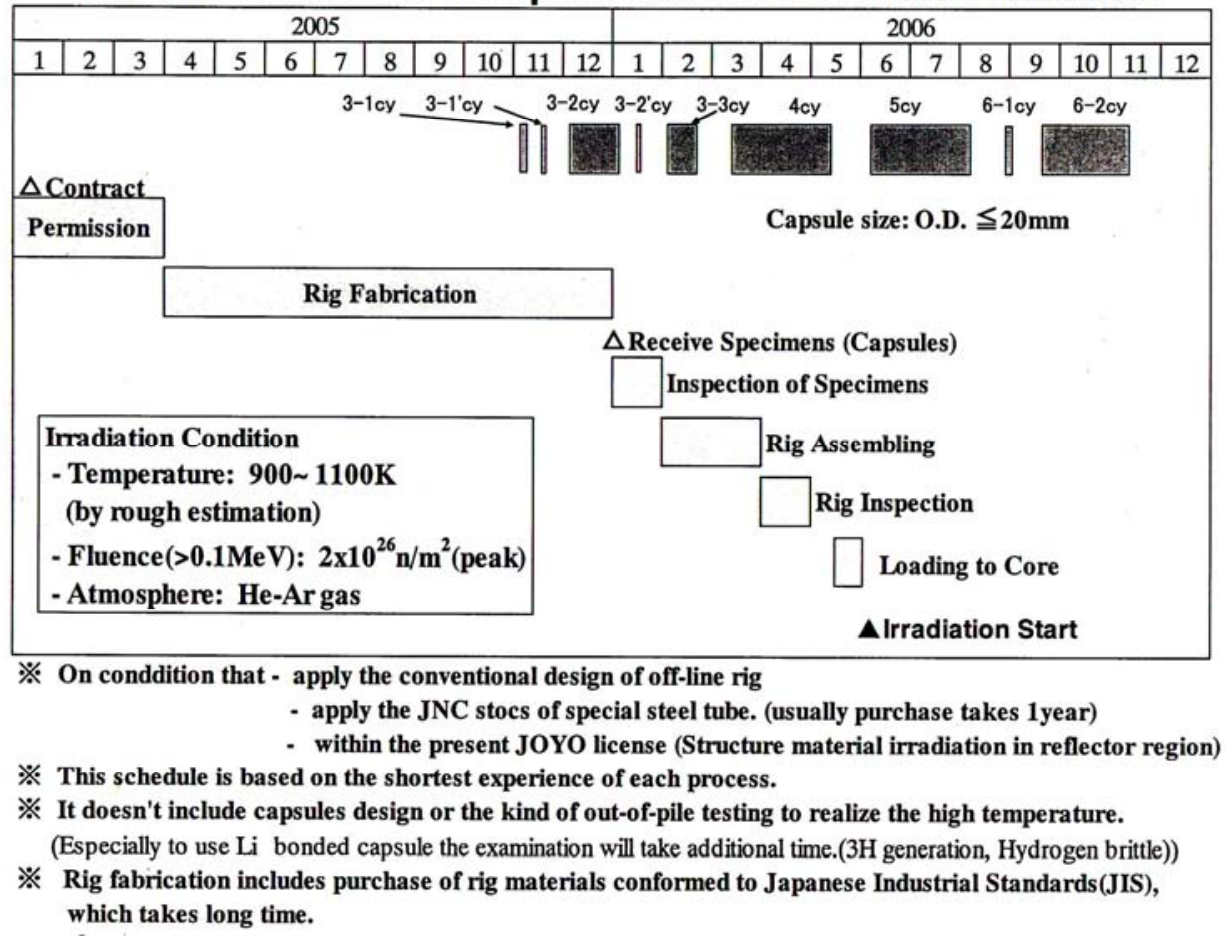

Figure 2. Schedule for Proposed Structural Materials Irradiation Experiment

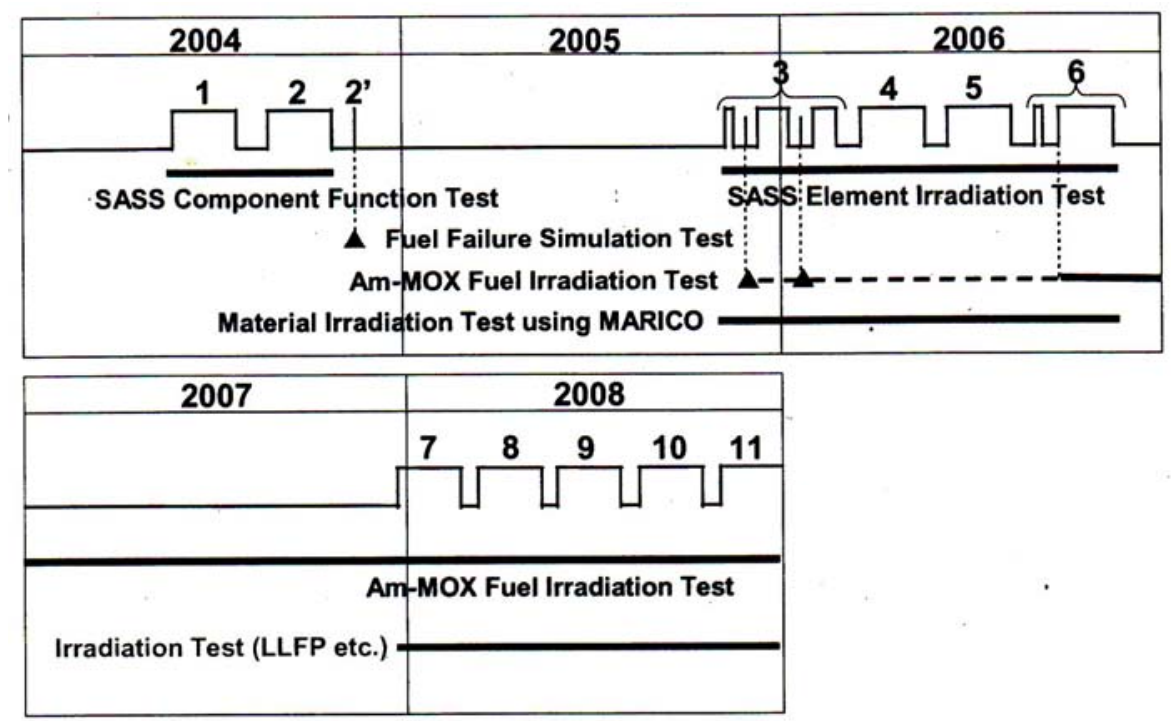

Figure 3. JOYO Operational Schedule for 2004 Through 2008 


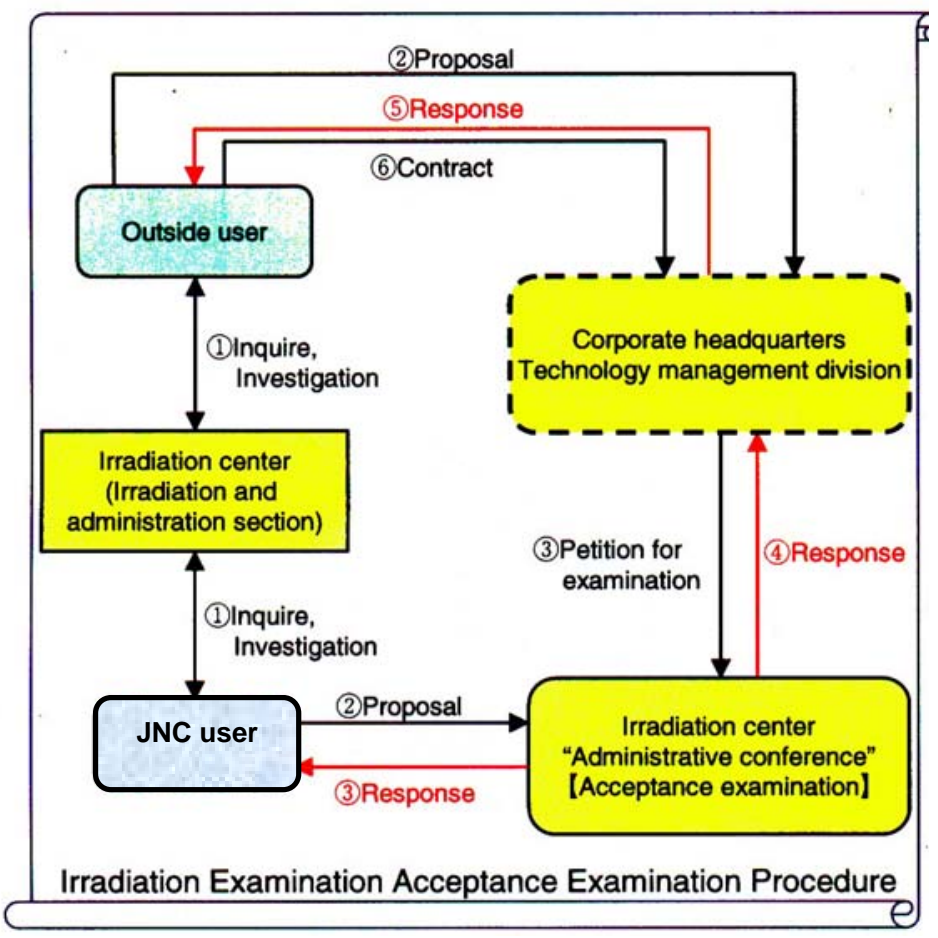

Figure 4. JOYO Irradiation Experiment Proposal Process

In an effort to meet a challenging schedule, a contracting strategy was developed by PNNL which broke down the work into smaller contracting phases. The first phase was designed to allow the procurement of long lead items (i.e., the fabrication of parts to be used in the assembly of two structural material irradiation rigs [SMIRs]). The second phase would then support the irradiation of capsules. The third and final phase would then support the post-irradiation examination (PIE) and/or shipment of test specimens back to the US for PIE.

Initially the planning basis assumed that unsealed capsules would be sent to JAEA for welding; however, during a visit in March 2005 and subsequent teleconferences it became clear that the technology to weld capsules containing refractory specimens did not exist at JAEA and would take a considerable effort to create and develop. Therefore, it was decided by mid April 2006 that Bettis Laboratory would take on responsibility for loading the specimens into capsules and seal welding the end caps. PNNL would take on responsibility for shipment of the sealed capsules to Japan, including the evaluation of all export laws and shipping requirements. 


\subsection{Fabrication of SMIR Parts - Phase 1A/1B}

A draft Statement of Work to procure a sufficient number of parts to assemble two SMIRs was reviewed during the joint JAEA/PNNL/NRPCT/DOE meeting at Oarai Engineering Center in late February and early March 2005. At the conclusion of the meeting and afterward, this was referred to as the Phase $1 \mathrm{~A}$ contract. The original goal, as discussed earlier, was to conclude negotiations and sign the Phase 1A contract before April 2006. However, by mid-March it was clear that this would not happen due to ongoing negotiations associated with the contract terms and conditions. Originally, a separate contract (Phase 1B) to support JAEA's involvement in the Design Review for Permission was envisioned. However, as contract negotiations extended into late March, the content of the Phase 1B Statement of Work was combined with the Phase 1A Statement of Work. The resulting Phase 1A/1B Statement of Work is included in Appendix C in its final form (dated April 28, 2005). Appendix D contains the final contract agreement that was signed by Mr. Doug Akers on May 17, 2005 on behalf of PNNL and Yoshinori Ogata on 19 May 2005 on behalf of JNC.

The Phase 1A/1B Statement of Work specified four deliverables with associated schedule deadlines. Table 1 lists the deliverables, deadlines, and actual completion dates. The subcontract placed by JAEA for fabrication of SMIR parts was with Nuclear Fuel Industries, Ltd, a Japanese fuel vendor. The Statement of Work specified that PNNL may elect to perform a source verification of the received SMIR parts. Because the project was cancelled in September 2005 and the rigs would not be assembled or used as part of Project Prometheus, PNNL decided to waive the right to source verification (Akers 2005), thereby allowing JAEA to conclude the final deliverable of the Phase 1A/1B contract earlier than the specified deadline of 31 March 2006. The final negotiated cost to procure and receive all the parts for the two SMIRs (Phase 1A) was $¥ 47,021,788$, which was equivalent to $\$ 435,387$ (assuming an exchange rate of $¥ 108=\$ 1$ ). The final negotiated cost for Phase 1B was $¥ 2,981,600$, which was equivalent to $\$ 27,607$ at the same exchange rate. In November 2005, PNNL purchased from US Bank a foreign exchange contract to buy yen between February 1 and February 28, 2006 at a guaranteed rate of $¥ 114.2$ to the dollar.

Table 1. Phase 1A/1B Contract Deliverables, Deadlines, and Actual Completion Dates

\begin{tabular}{|l|l|l|}
\hline \multicolumn{1}{|c|}{ Deliverable } & \multicolumn{1}{c|}{ Deadline } & \multicolumn{1}{c|}{$\begin{array}{c}\text { Actual Completion } \\
\text { Date }\end{array}$} \\
\hline $\begin{array}{l}\text { Schedule Design Review for } \\
\text { Permission }\end{array}$ & On contract award & 19 May 2005 \\
\hline Hold Design Review for Permission & $\begin{array}{l}\text { On or about 28 June } \\
\text { 2005 }\end{array}$ & 27-30 June 2005 \\
\hline Award contracts for SMIR parts & 31 July 2005 & 27 June 2005 \\
\hline Receive all SMIR parts & 15 March 2006 & $\begin{array}{l}\text { Expected 31 January } \\
\text { 2006 }\end{array}$ \\
\hline
\end{tabular}





\subsection{Irradiation Services Planned-Phase 1C}

As discussed previously, the target cycle for this irradiation effort was JOYO Cycle 5. Cycle 5 was scheduled to begin June 2006 and would be followed by a normal 20-day refueling outage before starting Cycle 6. A draft statement of work (SOW) was prepared by PNNL based on technical information provided by NRPCT. The SOW was reviewed with JAEA during a July 2005 meeting. A copy of the draft SOW is provided in Appendix E. The activities specified in the irradiation SOW are summarized here:

- Review of capsule assembly certification package

- Participation in a trial shipment of dummy capsules for the purpose of verifying an adequate shipping process

- Application for an Export License so that future technical data can be provided to PNNL (e.g., Irradiation Test Report, future PIE results and technical support data as required by the NRPCT in support of this program)

- Detailed calculations of capsule and specimen radioactivity to support PIE and capsule handling after irradiation

- Receipt and inspection of 70 (60 plus 10 spares) NRPCT sealed test capsules (spares were to be solid steel and intended as backups)

- Final assembly and loading of capsules into two SMIRs

- Insertion of SMIRs into the JOYO reactor in predetermined locations

- Irradiation of NRPCT capsules in JOYO cycles 5 and 6 and preparation of an Irradiation Test Report

- Extraction of SMIRs from the JOYO reactor after irradiation, removal of the capsules from the SMIRs, and limited inspections

- Final disposal of the irradiation rig hardware owned by JAEA

- Overall project management.

An estimated contract value associated with this work scope is provided in Table 2. The yen estimates were provided by JAEA in informal emails to allow PNNL to develop budget estimates. These estimates were never finalized. A formal request for proposal was never sent, and, therefore, a formal bid was not received. The neutron fee was estimated based on JAEA's published neutron fee which was based on capsule averaged fluence and compartment volume. The cost to waste dispose for the irradiated rigs and any hot cell waste generated during handling of the rigs and removal of the capsules was not estimated. The waste disposal costs were the greatest unknown costs and as of September 2005 JAEA had not been able to provide any cost estimate for waste disposal. 
Table 2. Estimate JAEA Contract Value for Irradiation Effort

\begin{tabular}{|c|c|c|c|}
\hline Tasks & Description of Tasks & Yen Estimates & Unburdened Dol \\
\hline 1 & $\begin{array}{l}\text { JNC Participate in Detailed Design Review (95\% design review) } \\
\text { and obtains design certification }\end{array}$ & $9,596,600$ & $\$ 88,677$ \\
\hline 2 & $\begin{array}{l}\text { JNC review and approve capsule assembly procedures, weld } \\
\text { procedures, and weld qualification report. }\end{array}$ & $3,438,000$ & $\$ 31,769$ \\
\hline 3 & JNC receive, inspect, and load 60 capsules & $3,153,900$ & $\$ 29,143$ \\
\hline 4 & JNC assemble 2 SMIRS & $7,329,960$ & $\$ 67,732$ \\
\hline 4 & Additional Materials needed for Rig Fab & $20,000,000$ & $\$ 184,809$ \\
\hline 5 & JNC Insert SMIRs into JOYO (included in neutron fee) & 0 & $\$ 0$ \\
\hline 5 & Neutron Fee & $197,114,338$ & $\$ 1,821,422$ \\
\hline 5 & Irradiation Test Fee (2 SMIRs) & 120,000 & $\$ 1,109$ \\
\hline 6 & JNC prepares Irradiation Test Report providing irradiation data & $5,105,200$ & $\$ 47,174$ \\
\hline 7 & JNC remove rig B after cycle 5 (included disassmbly costs) & 0 & $\$ 0$ \\
\hline 7 & JNC remove rig A after cycle 6 (included in disassembly costs) & 0 & $\$ 0$ \\
\hline 7 & Disassemble SMIRs (Dismount Cost 2 rigs) & $128,245,200$ & $\$ 1,185,042$ \\
\hline 8 & $\begin{array}{l}\text { JNC manage effort, prepare monthly report, and participate in } \\
\text { routine exchange of email and phone calls }\end{array}$ & $12,566,400$ & $\$ 116,119$ \\
\hline 9 & Waste Disposal Costs for SMIRs & $\begin{array}{c}? \\
386669598\end{array}$ & $\begin{array}{r}? \\
\$ 3572\end{array}$ \\
\hline
\end{tabular}

In anticipation of a contract award, a Supplier Quality Assurance (QA) Survey was conducted in July 2005 at the Oarai site. The survey, based on activities proposed under the irradiation portion of the work scope, focused on JAEA's Experimental Reactor Division and Irradiation and Administration Sections. The survey was conducted using machine translated Implementing Quality Program and Implementing Procedures and required the use of translators/interpreters. The purpose and intent of the survey was to conduct pre-award authorization to evaluate that the Experimental Reactor Division and the Irradiation and Administration Section had a documented QA program and that their program was being effectively implemented. The QA program was to meet Japanese Requirements (JEAC-4111-03 which generally corresponds to the general requirements of ISO-9001-00). Ultimately both the Experimental Reactor Division and the Irradiation and Administration Section were to be included on PNNL's Evaluated Supplier Listing (ESL); however, because the project was cancelled PNNL's ESL was not updated. The survey concluded that the Experimental Reactor Division and the Irradiation and Administration Section had documented and were implementing the applicable requirements of their QA program to satisfy the requirements in JEAC-4111. The most significant departure from ISO requirements observed during the survey was that JAEA could not meet the requirement to have inspections performed by persons who are independent of the work. Such an approach is not consistent with quality in Japan. Quality in Japan is built into every process and therefore they do not require the independence that is typical of US nuclear quality assurance activities. To fully meet ISO requirements would require PNNL oversight during more frequent source inspections.

At the very start of the project concerns regarding nuclear hazard indemnification were raised. Because the definition of nuclear incident includes occurrences outside the United States that involve byproduct material owned by, and used by or under contract with the United States, the Price-Anderson Amendments Act (PAAA) would apply to the irradiation of advanced structural materials in the JOYO experimental reactor. PNNL recommended that nuclear indemnification language be included in a DOE/JAEA agreement to address the risk of liability that might occur as a result a nuclear incident 
potentially caused by, or associated with, the irradiation of structural materials in the JOYO Experimental Fast Reactor. In the event that it was not possible to include such language in an international agreement, standard government contract language would need to be negotiated as part of any contract with JAEA. A draft nuclear hazards indemnity clause was prepared and sent to JAEA for review and comment; however, the project was cancelled before PNNL could engage JAEA in any serious discussions.

Defining the technical work scope was far easier than attempting to define the appropriate international agreement under which this work would be performed. Initially, in the January 2005 timeframe, PNNL and JAEA had informal discussions about how best to move forward with this work in the area of international agreements. During these preliminary discussions it was concluded that the following agreements were in affect and the proposed irradiation experiment would need to be performed within the bounds of the existing agreements:

1. Agreement for Cooperation between the Government of the United States of America and the Government of Japan concerning peaceful uses of Nuclear Energy (referred to as the "Agreement for Cooperation").

2. Agreement between of the Department of Energy of the United States of America and the Japan Nuclear Cycle Development Institute in the field of Nuclear Technologies (referred to as the "Nuclear Technologies Agreement").

Under the Nuclear Technologies Agreement, a Specific Memorandum Agreement (SMA) was needed to cover the specifics related to the irradiation of structural materials to support a space reactor development program. The Nuclear Technologies Agreement was in force until August 22 ${ }^{\text {nd }}, 2005$, when it expired. Discussions early on with both DOE Nuclear Energy (Program Office that originated the Nuclear Technologies Agreement) and JAEA indicated that an SMA could be issued prior to August $22^{\text {nd }}$ and be effective for the duration of the SMA as agreed to by both parties.

PNNL prepared a draft SMA to address the requirements of the Nuclear Technologies Agreement. A copy of that original draft is included in Appendix F. The draft was provided to NRPCT, which in turn provided it to Naval Reactors. In this particular case, Naval Reactors would be the "Program Office" responsible for initiating any international agreement needed to support this project. The development of any international agreement would require close coordination with the DOE Office of International Science and Technology Cooperation (PI-31). Consultation with PI-31 yielded a final version of the SMA which in turn was provided to JAEA as a draft for review and comment. After several discussions among Naval Reactors, JAEA, and DOE Tokyo (an organization used as an intermediary to facilitate discussions), agreement was reached as to the appropriate language to be included in the final draft SMA. Naval Reactors had obtained signature authority for the SMA from the Secretary of Energy. JAEA then forwarded the draft SMA to their Ministry of Education, Culture, Sports, Science \& Technology, at which point MEXT raised several issues.

In August 2005, both PNNL and NRPCT staff participated in meetings at the Oarai Engineering Center and discussed the status of the proposed SMA. During that meeting it became clear that the SMA approach would not be acceptable to MEXT. JAEA stated that MEXT would not allow JAEA to sign the SMA until DOE-IA provided a formal response regarding a MEXT request to DOE-IA to extend the NTA. This issue was not satisfactorily resolved prior to the expiration of the NTA. JAEA stated that negotiations related to Phase $1 \mathrm{C}$ - specimen irradiation - could continue in parallel with the development of a new agreement between DOE and JAEA to replace the Nuclear Technologies Agreement and that 
such an agreement would need to be in place by April 2006. The Phase 1C contract could not be signed until a new agreement was in place. Having an agreement in place by April 2006 was problematic. 


\subsection{Long Lead Items to Support Future Irradiation Efforts-Phase 2A}

During a joint JAEA/PNNL/NRPCT/DOE meeting at the Oarai Engineering Center in late February and early March 2005, consideration was given to future irradiation efforts (i.e., in addition to the planned JOYO cycle 5/6 irradiation of two SMIRs). During the discussion, JAEA expressed concern as to the availability of 316 stainless steel billets for building additional irradiation rigs. The cost to obtain additional material to build two more irradiation rigs was estimated on the high side to be $\$ 150 \mathrm{~K}$. The schedule to obtain this material was estimated to be about a year. Given the time frame needed to obtain funding authorization, establish a contract with JAEA, to have JAEA issue a contract for fabrication of specialty 316 billets, and then to have a steel mill pour the steel and form the billets, it was considered prudent and low risk to make an initial $\$ 150 \mathrm{~K}$ investment in raw materials. This would allow for NRPCT participation in a Cycle 7/8 JOYO irradiation campaign at some future time. A timeline showing the need for purchase of long lead items to support future irradiation efforts is provided in Figure 5.

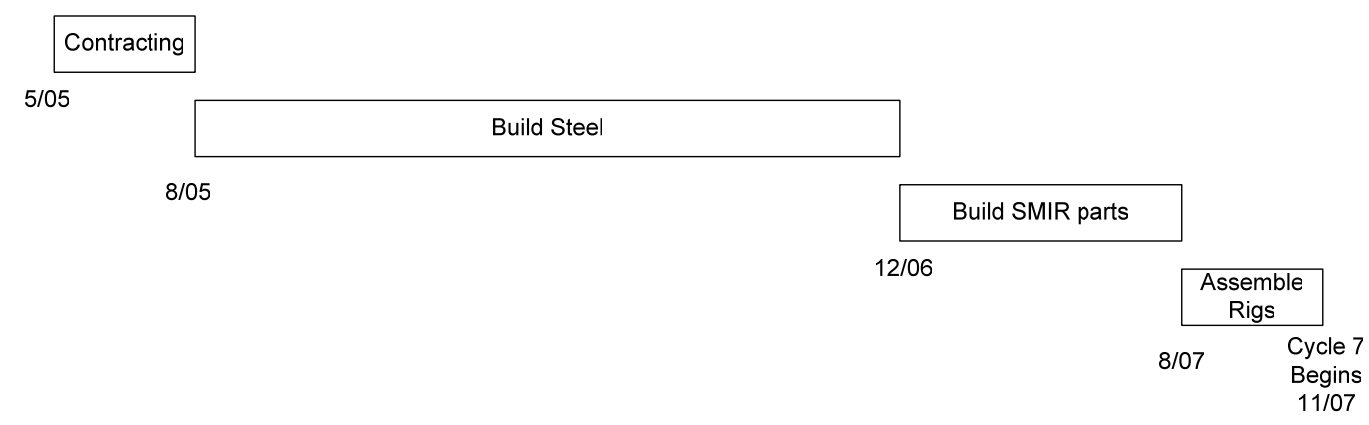

Figure 5. Timeline for Purchase of Long Lead 316 Stainless Steel Billets

A draft Statement of Work was prepared by PNNL in the May timeframe and sent to JAEA for review. No response was ever received; however, in about the July timeframe JAEA reported that they had found additional wrapper tubes which could be used in a Cycle 7/8 irradiation campaign and therefore, did not believe the schedule warranted purchase of more material at such a time. The draft SOW is provided in Appendix G. 



\subsection{Transport of Capsules to Japan}

As part of the JOYO irradiation effort, PNNL was tasked to manage and oversee the shipment of unirradiated specimens and capsules from the US to Japan. PNNL discussed how best to ship these specimens with both JAEA and their contacts at Mitsubishi Corporation. JAEA indicated that they would prefer not to be the Importer of Record for these capsules since they had little experience in this area. After discussions with Mitsubishi contacts, PNNL concluded that the best way to ship these capsules was to hire Nippon Express to be the Importer. Nippon Express is a company that ships internationally, is headquartered in Japan, and has offices in the US. PNNL contacted Nippon Express' Seattle office. Company contact information is provided:

Nippon Express USA, Inc.

Seattle Branch/Air Export

5530 S. 226th St.

Kent, WA 98032

Phone: (253) 867-5255

Fax: (253) 867-0440

http://www.nipponexpressusa.com/home.html

The plan was to ship a "trial shipment" of five sealed capsules containing actual pressurized biaxial creep specimens in December 2005 to eliminate uncertainties related to schedule and expectations associated with paper work. It was PNNL's understanding that the capsules would be packaged at Bettis in a pelican case as shown Figure 6. The final shipment of capsules was scheduled to be completed in mid February and would have incorporated lessons learned from the trial shipment.

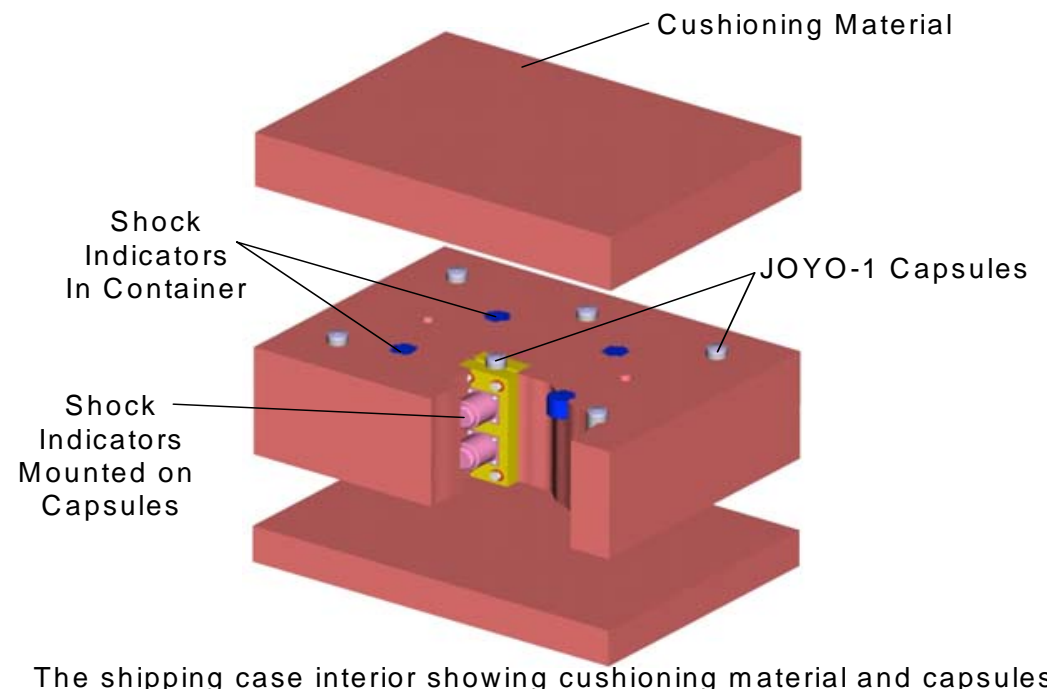

Figure 6. Internals of Pelican Case for Shipment of Sealed Capsules

Preliminary discussions with Nippon Express were underway when the project was cancelled; as a result, specifics related to the following items were not developed: 
- What is the approximate lead time to setup the shipment?

- What is the approximate cost for the shipment?

- How long will shipment take to ship to Japan?

- How long will it take to clear Japanese Customs?

- Does Nippon Express agree with what information needs to be included in the package to clear Japanese customs?

With regards to the last question posed to Nippon Express, JAEA provided PNNL a list of issues to be considered during import based on their preliminary discussions with authorities at their local Prefecture. These issues were as follows:

- All biaxial creep specimens with more than 1MPa (145 PSI) should be inspected by Chiba-prefecture (in the case of Narita Airport shipment) under Japanese Highly Pressurized Gas Safety Law, not by Customs. (Note: the details of how to inspect these specimens sealed within the capsules needed to be worked out.)

- The technical data that would need to accompany the specimens would include the following:

- Certificate of imported gas such as chemical analysis data, purity, total volume, maximum filling pressure, etc.

- Name and address of gas filler.

- Name and address of manufacturer of gas container (i.e., in-pile creep specimen).

- Certificate of gas filling such as, specimen ID, design test temp, design hoop stress, fill gas, internal pressure, fill gas volume, for each specimen.

- Table (list) of imported specimen and irradiation capsules.

- Technical drawing of in-pile creep specimen which shows structure and gas filling volume.

- Technical data of in-pile creep specimen, such as material data, metallurgical data for welded region (plug-cladding and gas filling hole) to assure the safety

- An application would need to be submitted to the Tokyo Customs for tax exemption for scientific/educational purposes.

With regards to meeting US requirements for shipping the pressurized specimens (i.e., biaxial creep specimens) PNNL had planned to ship the capsules internationally in accordance with International Air Transportation Association (IATA) Dangerous Goods Regulations (DGRs). The IATA DGRs are based on the International Civil Aviation Organization (ICAO) Technical Instructions for the Safe Transport of Dangerous Goods by Air. PNNL would have requested that Bettis package and label the shipment as "Dangerous Goods in Excepted Quantity" per IATA DGRs section 2.7 which allows exceptions based on:

- No more than $30 \mathrm{~mL}$ water capacity per inner packaging, and

- No more than $1 \mathrm{~L}$ water capacity per package.

Clearly the pressurized biaxial creep specimens (inner packaging) with a volume of $<7 \mathrm{~mL}$ water capacity would meet these requirements. With a maximum of 3 pressurized specimens per sealed steel 
capsule (intermediate packaging) and 6 steel capsules per pelican case no more than 18 specimens would be packaged in each case and therefore the volume (i.e., $\sim 130 \mathrm{~mL}$ ) would meet the no more than $1 \mathrm{~L}$ water capacity per package criteria.

PNNL was also tasked to assess what if any export licenses might be needed to support the shipment of capsules to Japan. To achieve this goal PNNL's Export Control Coordinator researched numerous sources of information based on the following list of materials to determine if an export license would be needed. Advance planning was done to ensure that ample time was allowed for application of an export license by PNNL if needed.

\section{- Refractory Alloys}

- FS-85 (62Nb-27Ta-10W-1Zr)

- ASTAR $811 \mathrm{C}(90 \mathrm{Ta}-8 \mathrm{~W}-1 \mathrm{Re}-0.7 \mathrm{Hf}-0.025 \mathrm{C})$

- Mo-47Re (52.5Mo-47.5Re)

$-\mathrm{W}(100 \% \mathrm{~W})$

- $\operatorname{Re}(100 \% \operatorname{Re})$

- W-25Re $(75 \mathrm{~W}-25 \mathrm{Re})$

- Ni-Base Alloys

- Nimonic PE16 (42Ni-33Fe-18Cr-4Mo)

- Alloy 617 (51Ni-22Cr-12.5Co-9Mo-3Fe)

- Haynes 230 (53Ni-22Cr-5Co14W-3Fe-2Mo)

\section{- Ceramics}

- $\mathrm{SiC}$ (silicon carbide monolithic)

- $\mathrm{SiCf} / \mathrm{SiC}$ (Woven Hi-Nicalon Type $\mathrm{S}$ ( $\mathrm{SiC}$ ) fiber in a chemical vapor infiltration $\mathrm{SiC}$ matrix)

- $\mathrm{BeO}$ (Beryllia)

The DOE Sensitive Subjects List which identifies Nuclear Reactor Systems, Subsystems, and associated technologies (for space reactors) as an area that MAY contain sensitive information and need export control referred to the following documents for more detailed information:

- Department of Commerce Export Administration Regulations (15 CFR Parts 730-774)

- Nuclear Regulatory Commission Regulations (10 CFR Part 110)

- Department of Energy Regulations (10 CFR Part 810)

- Department of State International Traffic in Arms Regulations (22 CFR Parts 120-130).

The Dept. of Commerce (DOC) Export Administration Regulations (EAR) defers to the Dept. of State (DOS) Directorate of Defense Trade Controls (DDTC) with regard to reactor technology. The DOS 
International Traffic in Arms Regulations (ITAR) has nothing specific relating to space reactor power systems.

PNNL contacted the Nuclear Regulatory Commission concerning the shipment of these materials and was advised that none require NRC licensing for export to Japan. NRC regulations (10 CFR Part 110) pertain to commercial reactor technology and dual-use applications not specific to space reactor technology. Any review against the Department of Energy Regulations (10 CFR Part 810) would take place in conjunction with a Department of Commerce Export Control determination. Therefore, if there are no DOC issues then there should not be a DOE issue.

The Department of Defense (DoD) Militarily Critical Technologies List (MCTL) was reviewed. Section 13 identifies the following as key technologies for developing, building, and operating nuclear fission reactor systems:

- Fuel fabrication techniques

- Critical instrumentation and control technologies

- Space-based and naval nuclear reactors for propulsion.

Advanced structural materials were NOT included in this list. The Department of Commerce controls export of Ni-base alloys with:

- A stress-rupture life of 10,000 hours or longer at $923 \mathrm{~K}$ (650 deg .C) at a stress of $676 \mathrm{MPa}$; or

- A low cycle fatigue life of 10,000 cycles or more at $823 \mathrm{~K}$ (550 deg. C) at a maximum stress of $1,095 \mathrm{MPa}$.

The Department of Commerce regulates the export of beryllium metal or alloys containing more than $50 \%$ beryllium by weight, beryllium compounds, manufactures thereof, and waste or scrap of any of the foregoing.

It was judged that some or all of the Ni-base alloys in the specimen material list could fall within one or the other of the Ni-base alloy criteria based on available literature data. Also, the $\mathrm{BeO}$ was judged to be covered by the criterion describing Be compounds. PNNL reviewed the Ni-base alloy and Be compound criteria against the Country List and found that none of these materials are controlled when shipping to Japan. The conclusion was that an Export license is NOT required to ship the proposed advanced structural materials to Japan. 


\subsection{Shipment and Disposal of Radioactive Waste, Irradiated Capsules and Test Specimens}

Preliminary post-irradiation radioactivity and decay heat rates were estimated for the proposed JOYO material irradiation test subassemblies in the JOYO test reactor core locations 6A4 and 6D4 during Cycle 5 and Cycle 6. ORIGEN-S calculations provided an upper estimate of the activation and decay heat produced in the 60 sample capsules. Subassembly test capsule compositions were based on Elemental Makeup Revision 1A.

The objectives of these calculations were twofold. The first objective was to estimate the number of Hanford waste packages that would be required to dispose of waste generated by the JOYO material irradiation test. The second objective was to provide a rough estimate of the radioactivity and decay heat associated with the irradiated test capsules and specimens to determine how many shipping casks would be need to transport these materials to the US. The activation of materials irradiated in JOYO will impact both the quantity of waste packages and the decay heat. The material activation is dependent on both the neutron fluence and the neutron spectra; both the fluence and spectra vary significantly between the different capsules. Since the activation varies significantly between capsules, three capsule locations were chosen to provide a bounding estimate for the radioactivity and decay heat.

The three capsule locations chosen were Tier 3 compartment $\mathrm{fl}$, Tier 1 compartment $\mathrm{fl}$, and Tier 1 compartment f6. The compartments are ordered by the NRPCT labeling of f1- f6, with f1 being closest to the core center and $\mathrm{f} 6$ being the farthest from the core center. Tier 1 is just below the active core; Tier 3 is at core center line. These locations represent the extremes in both total fluence and neutron spectra.

Elemental Makeup Revision 1A, containing compositions and elemental masses for each capsule, provided by NRPCT, was used to estimate the material activation in the capsules. Unfortunately, the proposed steel to build the capsules was not specified as "low cobalt steel," nor had any analysis of cobalt been performed to determine the actual amount of cobalt in the steel. Since the activation of cobalt in the steel would have a significant impact on the waste management cost associated with the capsule body and end cap materials, three different values of cobalt loading were assumed $-0.5 \mathrm{wt} \%, 1.0 \mathrm{wt} \%$, and 2.0 $\mathrm{wt} \%$. [Note: An analysis of the amount of cobalt was made at a later date by Bettis and found to be 0.046 $\mathrm{wt} \%$ which is typical of low cobalt nuclear grade steels. However, the ORIGEN-S model was not updated to reflect the actual value since the project was cancelled by the time the data was provided.]

The ORIGEN-S model made several simplifications to provide a bounding estimate for the material activation analysis. First, core locations $6 \mathrm{~A} 4$ and 6D4 were assumed to provide the same results, since they are in symmetric locations. Second, Tier 1 beginning of cycle 5 flux was used to represent the flux during both cycles 5 and 6; this will result in a slightly increased reaction rate in Tier 1 . The flux in Tier 3 does not change significantly with cycle burnup. Third, the calculation included an assumption that all of the material in each of the rigs (rig A or rig B) was placed at each of three locations: Tier 3 compartment $\mathrm{f1}$, Tier 1 compartment $\mathrm{fl}$, and Tier 1 compartment f6. For the calculation, the Rig A irradiation had 60 days at full power, 30 days at zero power, 60 days at full power, then the rig was discharged. For the calculation, the Rig B irradiation had 60 days a full power, 90 days at zero power, and then the rig was discharged. The results reported are the largest from any compartment for either long term waste management or shorter term transportation issues. Finally, the material activation rates for each compartment were normalized to activation rates for key isotopes calculated in a JOYO Cycle 5 MCNP model (Wootan 2005). The isotopes that had the reaction rates normalized include Fe-58, Ni-58, Ni-62, 
Co-59, and Ta-182; these nuclides were originally thought to have the most impact on disposal and transportation.

These preliminary ORIGEN-S results were used for two different purposes. The first purpose was to provide an upper estimate of the amount of waste that will be generated and disposed of at the end of the material evaluation. The second purpose was to determine how the material is to be transferred from the JOYO reactor to the JAEA hot-cells and how the material might be transferred from Japan to the United States in a shipping cask. The transportation evaluation considered both the radioactivity of the samples and the decay heat in the samples. Three years after irradiation the waste is dominated by Co- 60 . Co- 60 production is very sensitive to a lower-energy neutron spectrum so the highest Co-60 content is in Tier 1 compartment f6. Transportation of the samples in the first 180 days after irradiation is dominated by the Ta-182 in the samples. Ta-182 is less sensitive to the lower-energy neutron spectrum (compared to Co60 ) so the bounding compartment is Tier 1 compartment $\mathrm{fl}$.

The results of the ORIGEN-S calculations for waste disposal are shown in Table 3. The table assumes that the capsule material is made of $0.5 \mathrm{wt} \%$ Co steel, the $1.0 \%$ Co steel and the $2.0 \%$ Co steel. Table 4 shows the number of shielded waste package required to dispose of the capsules considering only the Co60 in the waste and the time after irradiation. (The cost of disposing one shielded waste package is on the order of $\$ 50,000$.)

Table 3. Upper Estimate of the Radioactivity from Both Rigs for Waste Disposal

$0.5 \mathrm{wt} \%$ Co Steel

Nuclide Radioactivity (Curies)

\begin{tabular}{|l|l|l|l|}
\hline Nuclide & 1 year & 2 years & 3 years \\
\hline Co 60 & 476 & 418 & 367 \\
\hline Ta 182 & 1188 & 131 & 14 \\
\hline Total & 1791 & 626 & 440 \\
\hline
\end{tabular}

$1.0 \mathrm{wt} \%$ Co Steel

nuclide radioactivity, curies

\begin{tabular}{|l|l|l|l|}
\hline Nuclide & 1 year & 2 years & 3 years \\
\hline Co 60 & 728 & 638 & 559 \\
\hline Ta 182 & 1188 & 131 & 14 \\
\hline Total & 2043 & 846 & 632 \\
\hline
\end{tabular}

$2.0 \mathrm{wt} \%$ Co Steel

nuclide radioactivity, curies

\begin{tabular}{|l|l|l|l|}
\hline Nuclide & 1 year & 2 years & 3 years \\
\hline Co 60 & 1230 & 1079 & 945 \\
\hline Ta 182 & 1188 & 131 & 14 \\
\hline Total & 2545 & 1287 & 1018 \\
\hline
\end{tabular}


Table 4. Shielded Waste Packages Required for the Materials in Both Rigs

\begin{tabular}{|l|l|l|l|}
\hline & 1 year & 2 years & 3 years \\
\hline $0.5 \%$ Co steel & 32 & 28 & 24 \\
\hline $1.0 \%$ Co steel & 48 & 42 & 37 \\
\hline $2.0 \%$ Co steel & 81 & 71 & 62 \\
\hline
\end{tabular}

The ORIGEN-S calculations for transportation are shown in Tables 5 and 6 . The results assume that the capsule material is made of $0.5 \mathrm{wt} \%$ Co-60 steel. For transportation in a shipping cask, the amount of Co in the capsules does not significantly impact the results because the relatively short-lived Ta-182 isotope dominates activity and decay heat during the first year after irradiation. The decay heat results of the ORIGEN-S calculations for transportation are shown in Table 6.

Table 5. Upper Estimate of the Radioactivity from Both Rigs for Transportation

nuclide radioactivity, curies

\begin{tabular}{|l|l|l|l|l|l|}
\hline Nuclide & Discharge & 30days & 0.25 years & 0.5 years & 1 year \\
\hline Co 60 & 1220 & 1140 & 1120 & 1080 & 1010 \\
\hline Ta 182 & 70500 & 23900 & 16600 & 9530 & 3170 \\
\hline Total & 1090000 & 37000 & 25800 & 15400 & 5810 \\
\hline
\end{tabular}

Table 6. Upper Estimate of the Decay Heat from Both Rigs for Transportation

Decay Heat, Watts

\begin{tabular}{|l|l|l|l|l|l|}
\hline Nuclide & Discharge & 30 days & 0.25 years & 0.5 years & 1 year \\
\hline Co 60 & 7.3 & 6.8 & 6.7 & 6.5 & 6.0 \\
\hline Ta 182 & 630 & 213 & 148 & 85.2 & 28.3 \\
\hline Total & 3720 & 226 & 159 & 95.4 & 37.8 \\
\hline
\end{tabular}

These results are preliminary and a detailed analysis is likely to reduce both the radioactivity and decay heat. The tantalum radioactivity varies by a factor of 2.5 between Tier 1 compartment $\mathrm{fl}$, and Tier 1 compartment $\mathrm{f} 6$ or Tier 3 compartment f1. Tier 1 compartment $\mathrm{f} 6$ and Tier 3 compartment $\mathrm{f} 1$ are nearly identical. The cobalt radioactivity varies by a factor of 3.5 over these same compartments with Tier 1 compartment $\mathrm{f} 6$ having the highest Co-60 radioactivity. These variations are an example why simple interpolations between tiers or compartments will not produce reasonable results.

Based on the activity estimates described above and the estimated post-irradiation heating rates, JAEA estimated that a single shipment of the TN6-4 shipping cask would be adequate to return all the capsules and contents to the US. The specifications for the TN6-4 cask are included in Appendix H. The TN6-4 cask was previously used to ship spent fuel from JOYO to the Hanford Site in the US. The cask is presently licensed by the Japan government (expires 25 May 2007) and it is certified for international shipments of spent fuel by the IAEA. The cask was previously licensed by DOT in the US, but that license has expired. At the time it was licensed, lifting height restrictions were placed on the cask due to questions associated with its integral shock absorption system. JAEA expected that an application for a new license would have to address this issue.

JAEA provided estimates of the time and cost to prepare and ship the irradiated capsules back to the US using the TN6-4 cask. To obtain permission from the Japan government to make the shipment to the US, 
JAEA estimated a cost of approximately $\$ 100,000$ and up to one year. This estimate was developed based on the fact that isotopes not previously considered in the cask license (e.g., Ta-182) would be included in the shipment, and analysis to support extending the license to cover these isotopes probably would be required. To prepare an application for licensing in the US by the DOT (which would seek NRC review and approval), JAEA estimated costs of at least $\$ 300,000$ to $\$ 400,000$. This cost included anticipated analyses to determine whether the TN6-4 shock absorption system met current DOT

requirements. If the analysis revealed the shock absorption system would have to be modified, this would have represented an additional cost, which was never estimated by JAEA. The time to obtain the DOT license was estimated at 1.5 years, or longer if the shock absorption system had to be modified. JAEA estimated the cost to prepare and ship one TN6-4 cask containing all the irradiated capsules would have been $\$ 300,000$ to $\$ 400,000$.

With regard to waste disposal, it was established that the SMIR components would have been disposed of in Japan at JAEA expense because the Phase 1A/1B contract provided for JAEA ownership of the SMIRs themselves. During negotiations between DOE and JAEA on the Specific Memorandum of Agreement it was made clear that there was a reluctance on the part of the Japan government to accept US materials and secondary waste generated during PIE for radioactive material disposal in Japan, even if the waste disposal costs were paid by the US. The reason given was the limited volume of interim storage for radioactive waste in Japan. Therefore, it appeared likely that the irradiated capsules, capsule internals and specimens would have been returned in tact to the US.

In November 2004, Washington state voters passed Initiative 297 (I-297) that, among other things, prohibits importing radioactive waste onto the Hanford Site. On February $8^{\text {th }}$, 2005, the United States District Court ordered that I-297 be stayed pending completion of the Washington State Supreme Court certification process and subsequent resolution of the federal constitutional issues in the federal courts. Resolution is expected to require at least 12 to 18 months. The results of these current court actions will define the ultimate impact of I-297.

In the meantime, with a few specific exceptions, importation of radioactive wastes to the Hanford Site for disposal is currently prohibited. The Hanford Site is operating under a stipulation agreement issued by the United States District Court that prohibits Hanford from accepting most low-level and mixed lowlevel wastes that are generated off the site. This would include waste generated at the JOYO reactor or any other PIE testing facility in Japan.

The agreement does not, however, preclude disposal of wastes at Hanford that are generated at Hanford or at PNNL's Richland facilities. It also does not ban importation of radioactive samples and materials (i.e., unopened capsules or capsule pieces, specimen holders and specimens if the lab was performing retrospective dosimetry on these materials as part of the PIE). As a result, irradiated test specimens from the JOYO reactor may be received at PNNL for analysis and the secondary waste generated from test analysis conducted at PNNL may be disposed of at Hanford. But PNNL could not accept any secondary waste generated by JAEA in the disassembly of the capsules or as a result of PIE. As a result of this situation, an unsolicited proposal was submitted by PNNL to investigate an option to perform limited non-destructive PIE on the unopened capsules in Japan, with all destructive PIE performed in the US after receiving the shipment of irradiated capsules from JAEA (Senor and Painter 2005). The purpose of the submittal was to aid the NRPCT in formulating an overall PIE plan. 


\subsection{Lessons Learned}

In most cases, nuclear work performed overseas will require some form of an International Agreement. These types of agreements can take a year or more to put in place. It all depends on what country is involved (weapons state, non-weapons state, on the sensitive countries list, etc.) and the specific details in the agreement (i.e,, fuel verses non-fuel, indemnification and intellectual properties). Planning of such efforts should incorporate the schedule required to establish such agreements for specific work scope. These types of agreements normally require the involvement of other federal organizations (e.g., Department of Commerce and the Department of State).

As would be expected, communications were at times difficult. Phone conference calls only worked if there was a member fluent in English at JAEA — similarly, it would have been beneficial to have a person fluent in Japanese at PNNL.

Face-to-face discussions using well-prepared presentation materials were the most effective means of communications. However, on several occasions web conferencing was used to link JAEA and PNNL staff together to work out the details in written documents. Keeping the size of face-to-face meetings small appeared to be more productive and cost effective.

It was beneficial to have translators present during discussions involving contracts and quality; however, during discussions which focused heavily on the technical aspects of the irradiation experiment, the translation services were not as effective due to the nature of the technical discussions.

Based on PNNL's experience having a PNNL staff member occasionally onsite (a PNNL staff member was assigned an onsite fellowship with JAEA during several periods of this effort) it is recommended that any future irradiation effort of this magnitude identify program funding to create an onsite representative. During liquid metal breeder reactor development at Hanford the Japanese always had an on-site representative at PNNL or Westinghouse Hanford Company when conducting irradiation experiments at the Fast Flux Test Facility.

Aggressive irradiation testing schedules especially in overseas reactors will always be difficult. Differences in language, customs, laws, quality assurance standards, and business practices will take time to work through.

Although it would have been more expensive and taken more time, it would have been helpful to have some contract and technical documents written in both English and Kanji. Translation services are available in both the US and Japan.

Waste disposal costs were a big unknown. The issue seemed to be related to waste disposal in general. Apparently all waste generated by JAEA at the O'arai Engineering Center is stored on site until a long term low level waste facility can be established in Japan.

From PNNL's perspective, working with all levels of information (i.e., unclassified, classified and sensitive) and being able to use standard email and internet tools for information that is unclassified the use of CipherShare was restrictive, slow, inconvenient and cumbersome to use. As a result, project participants were reluctant to learn it and incorporate it as a routine communications and document sharing tool. From PNNL's perspective, where all information was clearly unclassified, the system seemed to add little value to the execution of the project and at times appeared to be a one-way conduit of 
information. On several occasions PNNL was informed that it was just too much trouble to upload documents onto CipherShare, and so the documents were faxed instead. It remains unclear as to the necessity and expense (i.e., engineering time) for such a cumbersome system to be used for unclassified, non-sensitive information. 


\subsection{References}

Akers, D. letter to Mr. Tajima JAEA Director of Industrial Collaboration Promotion Department, dated December 29, 2005. Subject: Cancellation of Plan to Irradiate Advanced Structural Materials in JOYO Experimental Fast Reactor to Support Space Reactor Development Program for NASA

Senor, DJ, DM Paxton, and AW Prichard. 2005. "Feasibility Study for an Overseas High Fluence Irradiation Test in Support of Project Prometheus: Final Assessment of Candidate Reactor Facilities," PNNL-15124, Richland, WA: Pacific Northwest National Laboratory.

Senor, DJ and CL Painter. 2005. "A Concept for Rapid, Minimum-Cost Post-Irradiation Examination for the JOYO-1 Experiment," Space Reactor Materials Irradiation Project White Paper. Richland, WA:

Pacific Northwest National Laboratory.

Wootan, DW. 2005. "Heating Rates and Neutron Flux for JOYO-1 Irradiation Tests-

Revision 1,” PNNL-15250. Richland, WA: Pacific Northwest National Laboratory. 



\section{Appendix A}

Licensing Basis for the JOYO Reactor Core 



\section{Appendix A. Licensing Basis for the JOYO Reactor Core}

\begin{tabular}{|c|c|c|c|c|c|c|c|c|c|c|c|c|c|}
\hline 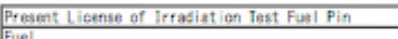 & Tppe 1 & Ty:en I & Type回 & Traen & \begin{tabular}{|l|l|} 
ATCB Tast Tyse I \\
\end{tabular} & \begin{tabular}{|l|l|} 
ATCO Test Tyee II \\
\end{tabular} & \begin{tabular}{|l|l|} 
PTCB Test Tyee区 \\
\end{tabular} & \begin{tabular}{|l|l|} 
RTCes Test Typen \\
\end{tabular} & \begin{tabular}{|l|} 
Gerbida fual Iest \\
\end{tabular} & Nitrido funl lest & PIY Test & Frou Testisitn $\$ \mid i t)$ & FFOL Tast (10afore ocos) \\
\hline $\begin{array}{l}\text { Fubl } \\
\text { Contust ible }\end{array}$ & & & & & & & & & & & & & \\
\hline 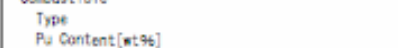 & vax pallet & wax pollet & $w 3 x P_{e} \mid l e t$ & $\operatorname{mix}$ pellet & $w x x$ Pell let & scx pallet & Nox Pallot & mox Pellet & wC Pal let & we Pallet & vox Pellot & wox Pellet & wax Pell let \\
\hline 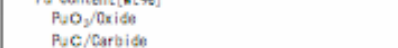 & $\leq 30$ & $\leq 30$ & $\leq 30$ & $\underset{x}{\leq 30}$ & $\underset{x}{s 0}$ & $\leq 30$ & $\leq 30$ & $\leq 30$ & $\underset{\leq 25}{x}$ & $\underset{x}{x}$ & $\leq 30$ & $\leq 30$ & $\begin{array}{c}\leq 30 \\
x\end{array}$ \\
\hline PuN/Nitride & $\stackrel{x}{x}$ & $\underset{x}{x}$ & $\underset{x}{x}$ & $\underset{x}{x}$ & $\underset{x}{x}$ & $\stackrel{x}{x}$ & $\stackrel{x}{x}$ & $\stackrel{x}{x}$ & $\stackrel{325}{x}$ & $\underset{\leq 30}{x}$ & $\stackrel{x}{x}$ & $\stackrel{x}{x}$ & ${ }_{x}^{x}$ \\
\hline $\begin{array}{l}\text { Pu/Notal } \\
\text { Pu Fissile Centent (ot } 06 \text { ] }\end{array}$ & $x$ & $x$ & $x$ & $x$ & $x$ & $x$ & $x$ & $x$ & $x$ & $x$ & $x$ & $x$ & $x$ \\
\hline 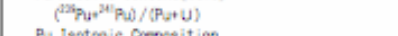 & - & - & - & - & - & - & ancion. & 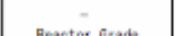 & 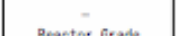 & - & - & - & - \\
\hline 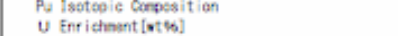 & $\mid \begin{array}{l}\text { Finctor orde } \\
\leq 48\end{array}$ & Reactor frabs & $\begin{array}{l}\text { Rinestor arobie } \\
\leq 26\end{array}$ & $\mid \begin{array}{c}\text { Finector } \\
\leq 24\end{array}$ & Fienctor Crade & 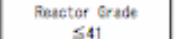 & $\begin{array}{l}\text { Fiesctor Grade } \\
\leq 26\end{array}$ & 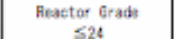 & Reactor frash & Reactor Girade & Alesctor Grads & Resctor Grads & Precotor Grade \\
\hline Pellet Initial Density[96. 0.] & $\leq 94$ & 587 & $\$ 95$ & $\begin{array}{l}356 \\
\leq 95\end{array}$ & $\leq 94$ & $\leq 87$ & $\leq 95$ & $\leq 95$ & 485 & $\leq 95$ & $87 \sim 66$ & 494 & 494 \\
\hline $\begin{array}{l}\text { Pellat Diester [n] }] \\
\text { Pallet canter Hole Disoter }[m]\end{array}$ & 446 & 45.4 & $5.3 \sim 7.5$ & $5.18 \sim 6.18$ & 446 & 45.4 & 5. $3 \sim 6.6$ & 5. $18 \sim 6.18$ & $\Rightarrow 1.4$ & $6.3 \sim 7.5$ & $=6.5$ & $=4.6$ & $\fallingdotseq 46$ \\
\hline $\begin{array}{l}\text { Pal let Coster Hole Dirnter [m] } \\
\text { Pal let Length [m] }\end{array}$ & $\leq \begin{array}{l}0 \\
15\end{array}$ & $\begin{array}{l}0, \neq 2 \\
\leq 15\end{array}$ & 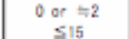 & 0 or $\leqslant 2$ & & $\underset{\leq 15}{0}$ & $\therefore$ & $\leq 15$ & 0 & 0 & $\therefore$ & $\therefore 15$ & 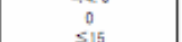 \\
\hline 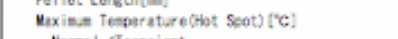 & & & & & & & & & & & & & \\
\hline 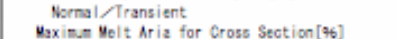 & $2,5 e 5 / 2,650$ & $2,540 / 2690$ & $2,540 / 2,600$ & $2,540 / 2,630$ & $2,540(2,600) / 2,600$ & $2.540(2,660) / 2,600$ & $2,540(2,680) / 2,600$ & $2,540(2,600) / 2,660$ & $1,930 / 2,140$ & $2.140 / 2.390$ & & $2.540 / 2690$ & 2. $5400 / 2.680$ \\
\hline 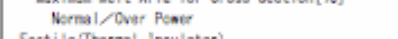 & $x$ & $x$ & $\mathrm{x}$ & $x$ & $\times$ & $\times$ & $\times$ & $x$ & × & $\times$ & $20 / 30$ & $\times$ & $\times$ \\
\hline $\begin{array}{l}\text { Farti le (Thernal Insulator) } \\
\text { Type }\end{array}$ & Junxale pallet. & un $x$ Din pelat. & Jurxan Pellat & 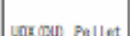 & nacous Pallet & unxery pellet & Inxon pellet & Intoran pellet & 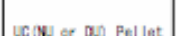 & "y.9. & Lingen gellet & Inxmen pellet & unxare Paliet \\
\hline Cledding Tube & & & & & & & & & 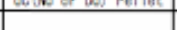 & 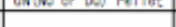 & & 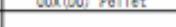 & \\
\hline Esterial & Nos & 135 & ${ }_{155}$ & FSS & ${ }^{A S S}$ & Ass & ASS & FSS & ass & ass & Bisi $\rightarrow$ A & SUSIEW & sulval6u \\
\hline 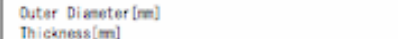 & $5.4 \% 5.8$ & $64 \sim 6.8$ & $64 \sim 8.5$ & $\begin{array}{r}6.5 \sim 7.5 \\
0.5 \sim 078\end{array}$ & $\begin{array}{l}5.4 \sim 5.8 \\
0.3 \sim 0.5\end{array}$ & $6.4 \sim 6.8$ & $6.4 \sim 7.5$ & $6.5 \sim 7.5$ & $=8.5$ & $7.5-4.5$ & $\Rightarrow 7.5$ & $\Rightarrow 6.5$ & $=5.5$ \\
\hline 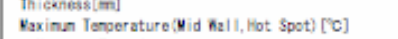 & $0.3 \sim 0.5$ & $0.4 \sim 0.6$ & $0.4 \sim 0.7$ & & & & & $0.56 \sim 0.76$ & $=0.45$ & $0.45 \sim 0.50$ & $\Rightarrow 0.4$ & $=0.35$ & 40.35 \\
\hline Soresel-Transient & & & & & & & & & & & & & \\
\hline $\begin{array}{l}\text { LN15-A } \\
\text { N1S-8 }\end{array}$ & $700 / 850$ & $700 / 990$ & $7002-850$ & $610 / 810$ & $750(690)<690$ & $750(990)>690$ & $750(490) / 690$ & $660(110) / 310$ & $x^{2}$ & 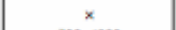 & $\hat{1}=0$ & & $x^{n}$ \\
\hline 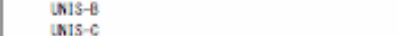 & $700<-690$ & $200 / 390$ & $700 / 850$ & $610 / 810$ & $709(6900) / 830$ & $709(8900) / 890$ & $700(895) / 690$ & $610(810) / 810$ & $700 / 390$ & $500 / 390$ & $650 / 890$ & $760 / 890$ & $702 / 830$ \\
\hline $\begin{array}{c}\text { w15 } \\
\text { sis-c }\end{array}$ & $702 / 850$ & $700 / 890$ & $709-850$ & $610 / 810$ & $x^{x}$ & $x_{200090}^{x}<30$ & ${ }_{700}^{\times}$ & $\stackrel{x}{x}$ & $x^{x}$ & $x^{x}=0$ & $x^{x}$ & $x^{x}$ & $\stackrel{x}{x}$ \\
\hline 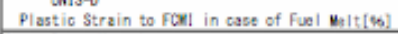 & $\times \times 0$ & $\times$ & $\times$ & $\times$ & $\times \times 000$ & $\times \times 000$ & $\times \times$ & $\times$ & $x$ & $\times x$ & $\leq 3$ & $x$ & $\begin{array}{l}x \\
x \\
x\end{array}$ \\
\hline Fther Parts Eaterial & & & & & & & & & & & & 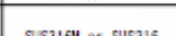 & \\
\hline $\begin{array}{l}\text { Ifd Plug } \\
\text { Spiral sit }\end{array}$ & ASS & NSS & ASS & FSS & ASS & t5s & ASS & FSS & ASS & 染S & 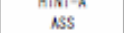 & 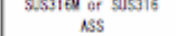 & 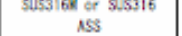 \\
\hline Pallet Tyoe Raflestor & ASS & ass & ass & FSS & ASS & ASS & ass & FSS & as & tis & NSS & & \\
\hline Plenum Soring & ASS & & 155 & ass & ass & A5S & ass & ass & SUISOAS & 5u153096 & sussofu & sussosy & s.155040 \\
\hline Plense slever & ss & ss & ss & $s s$ & ss & $s$ & ss & ss & ss & se & $s \mathrm{~s}$ & ss & ss \\
\hline senel (to sli it) & $\times$ & $x$ & $x$ & $x$ & $\times$ & $\times$ & $\times$ & $x$ & $\times$ & $\times$ & $x$ & $P_{0}-A_{6}$ All lay & \\
\hline 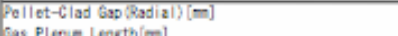 & 30.2 & 30.2 & 302 & 40.1 & 502 & 502 & 50.2 & 50.1 & 40.1 & 40.1240 .2 & $0.05 \sim 0.15$ & 40.1 & 401 \\
\hline Sas. Plenum Lengthime] & $\leq 500$ & $\sum_{600}^{5900}$ & $\leq 500$ & $\leq 900$ & $\begin{array}{l}5900 \\
<500\end{array}$ & $\leq 500$ & $s_{500}^{5900}$ & $\leq 900$ & $\leq 900$ & 5900 & $500-500$ & $\leq 550$ & $\leq 550$ \\
\hline 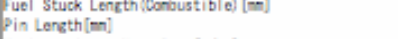 & $\begin{array}{l}5500 \\
52050\end{array}$ & $\begin{array}{l}5600 \\
52000\end{array}$ & $\begin{array}{r}5500 \\
\leq 2.000\end{array}$ & $\begin{array}{l}5500 \\
\leq 2000\end{array}$ & $\begin{aligned} 5500 \\
\leq 2050\end{aligned}$ & $\begin{array}{l}5500 \\
\leq 2.050\end{array}$ & $\begin{array}{l}\leq 500 \\
\leq 2000\end{array}$ & $\begin{array}{l}5500 \\
\leq 2000\end{array}$ & $\begin{array}{l}5600 \\
\leq 2.000\end{array}$ & $\begin{array}{l}\leq 500 \\
\$ 2.000\end{array}$ & $\begin{array}{l}\leq 5000 \\
1.500 \sim 1,800\end{array}$ & $\begin{array}{r}5500 \\
41.540\end{array}$ & $\begin{array}{l}5500 \\
51.560\end{array}$ \\
\hline Kaximan Liner Hest Rate $[\mathrm{F} / \mathrm{cm}$ ] & 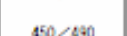 & $530-500+>-10$ & 4002520 & $500-640$ & 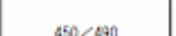 & $500-570$ & $400-520$ & $500<-40$ & $000=800$ & 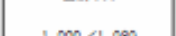 & 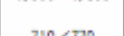 & 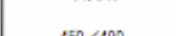 & 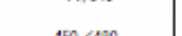 \\
\hline 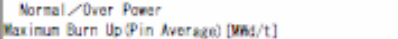 & $450 / \angle 90$ & & $405 \% 520$ & $500 / 540$ & $450 / \angle 90$ & $530 / 510$ & $400 / 520$ & $500 / 540$ & $800 / 870$ & $1.000 / 1.083$ & $710 / 770$ & $450 / 490$ & $450 / 250$ \\
\hline WNISA $A$ & 130.050 & 130.000 & 130,000 & 130,000 & 150,050 & 150,050 & 150,000 & 150,000 & & & $x^{x}$ & $x$ & $\times$ \\
\hline (W.IS- & & & & 130,000 & 200,050 & 200.050 & 200.000 & 200.000 & so & 75,000 & 1.000 & 1.000 & 1,000 \\
\hline UNIS- -6 & 130.030 & 139.600 & 130.000 & 130.000 & & $x$ & $x$ & ${ }^{x}$ & $x$ & $\times$ & $x$ & $x$ & $\times$ \\
\hline WNIS-0 & 130,080 & 130,000 & 130,000 & 130,000 & 200,080 & 200.050 & 200,000 & 200,000 & 50.000 & 75,000 & $\times$ & $x$ & $x$ \\
\hline $\begin{array}{l}{[\text { he }} \\
\text { WNS-A }\end{array}$ & $\leq 7$ & $\leq 7$ & s & $\leq 7$ & $\leq 1$ & $\leq 1$ & $\leq 1$ & $\leq 1$ & & & $x$ & $x$ & $x$ \\
\hline (wis-8 & & & & $=$ & $\leq 6$ & $\leq 6$ & $\leq 6$ & $\leq 6$ & $\leq 1$ & $\leq 24$ & $\leq 24$ & 2 & $i$ \\
\hline 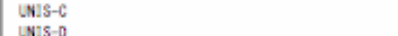 & $\leq 91$ & 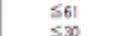 & $\leq 61$ & $\leq 6 !$ & $x_{56}^{x}$ & $x_{6}^{x}$ & $x_{<}^{x}$ & $x_{<}^{x}$ & 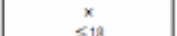 & $x^{x}$ & $\stackrel{x}{x}$ & $x^{x}$ & $\stackrel{x}{x}$ \\
\hline
\end{tabular}





\section{Appendix B}

Final JOYO Experiment Proposal Form 



\section{Appendix B. Final JOYO Experiment Proposal Form}

Submit all proposal to : Irradiation and Administration Section, Irradiation Center,
Oarai Engineering Center, Japan Nuclear Development Institute.
Phone \& FAX : 29-267-7109 E-mail : jy.shousha@jnc.go.jp

Title of proposal:

JOYO-1 Irradiation of Structural Materials for Prometheus Space Reactor

\begin{tabular}{|c|c|}
\hline Date received & \\
\hline $\begin{array}{c}\text { Proposal } \\
\text { number }\end{array}$ & \\
\hline
\end{tabular}

Date submitted :

July 8, 2005

Investigator : DJ Senor

Phone : +1-509-376-5610

FAX : +1-509-376-5824

Institution \& mail address :

Pacific Northwest National Laboratory

902 Battelle Boulevard, P.O. Box 999

MSIN P8-10

Richland, WA 99352

USA

E-mail : david.senor@pnl.gov

Citizenship : USA

The objective of the proposed experiment is the irradiation of candidate structural materials for potential use in the Prometheus 1 space nuclear reactor to evaluate their irradiation behavior and material properties. Test specimens will include metals, alloys, ceramics, and ceramic composites. There are five basic types of metal and alloy specimens that will be used for testing: 1) pressurized biaxial creep tubes, 2) tensile specimens, 3) fracture toughness bars, 4) thermal diffusivity disks, and 5) compact tension disks. There are four basic types of ceramic and ceramic composite specimens: 1) tensile specimens, 2) thermal diffusivity disks, 3) compression cylinders, and 4) bend stress relaxation strips. The goals are to achieve an irradiation test fluence similar to the space reactor mission fluences and expose the materials to a range of temperatures. The specimens will be contained in non-instrumented, gas-gapped capsules to be irradiated in the JOYO reflector region using the Structural Materials Irradiation Rig (SMIR). Based on preliminary capsule designs, it is expected that two SMIRs will be required to irradiate all the specimens proposed for this experiment. Each SMIR will contain 30

Outline of irradiation objective capsules (five capsules in each of six compartments). The goal is to begin irradiation of both SMIRs in JOYO Cycle 5 with one SMIR staying in the reactor for one cycle and the other for two cycles.

This proposal provides the most current summary information on specimens that are intended for irradiation in the proposed experiment. More refined details of the technical requirements for the capsules, specimens, and irradiation conditions are included in the design package that was provided to JNC in advance of the June 2005 Design Review for Permission (Ref: B-MT(EDT)S-014). The final details of the technical requirements for the capsules, specimens, and irradiation conditions will be included in a design package to be provided for a Detail Design Review (tentatively scheduled for September 2005). The contractual phases of the proposed experiment are as follows:

- Phase 1A, Procurement of parts for two SMIRs (Ref: PNNL Contract 17201)

- Phase 1B, Participation in Design Review for Permission (Ref: PNNL Contract 17201)

- Phase 1C, Irradiation and extraction of 60 capsules in two SMIRs

- Phase 1D, Post-irradiation examination (PIE) and waste disposal (To be determined) 


\begin{tabular}{|c|c|}
\hline \multirow{5}{*}{$\begin{array}{l}\text { Irradiation } \\
\text { Specimens }\end{array}$} & 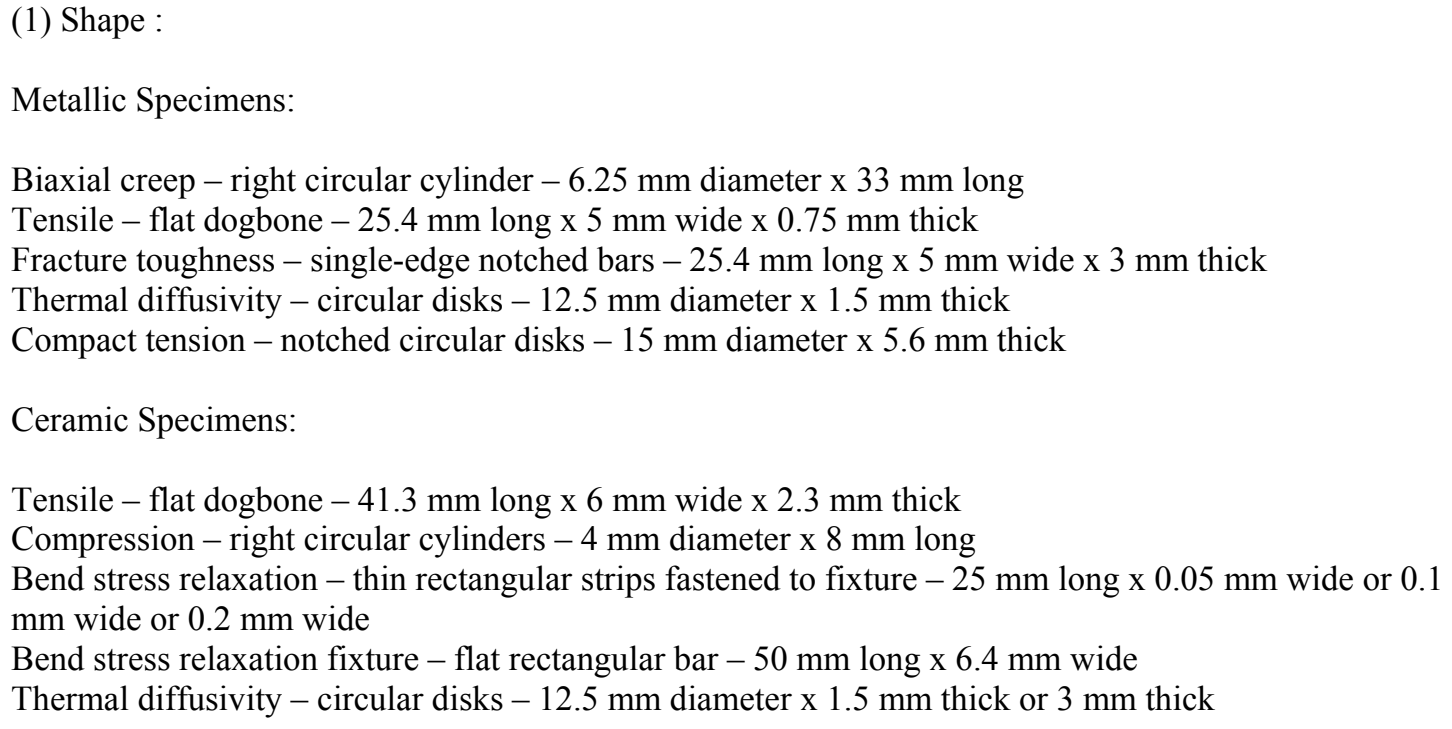 \\
\hline & $\begin{array}{l}\text { (2) Alloy or chemical signs : } \\
\begin{array}{ll}\text { Metallic Specimens: } & \\
\text { Refractory Metals } & \text { : FS-85, ASTAR-811C, Mo-47Re, Re, W, W-25Re } \\
\text { Ni-base Alloys } & : \text { Nimonic PE16, Alloy 617, Haynes 230 } \\
\text { Ceramic Specimens } & : \mathrm{SiC}, \mathrm{SiC}_{\mathrm{f}} / \mathrm{SiC} \text { composite, BeO }\end{array}\end{array}$ \\
\hline & 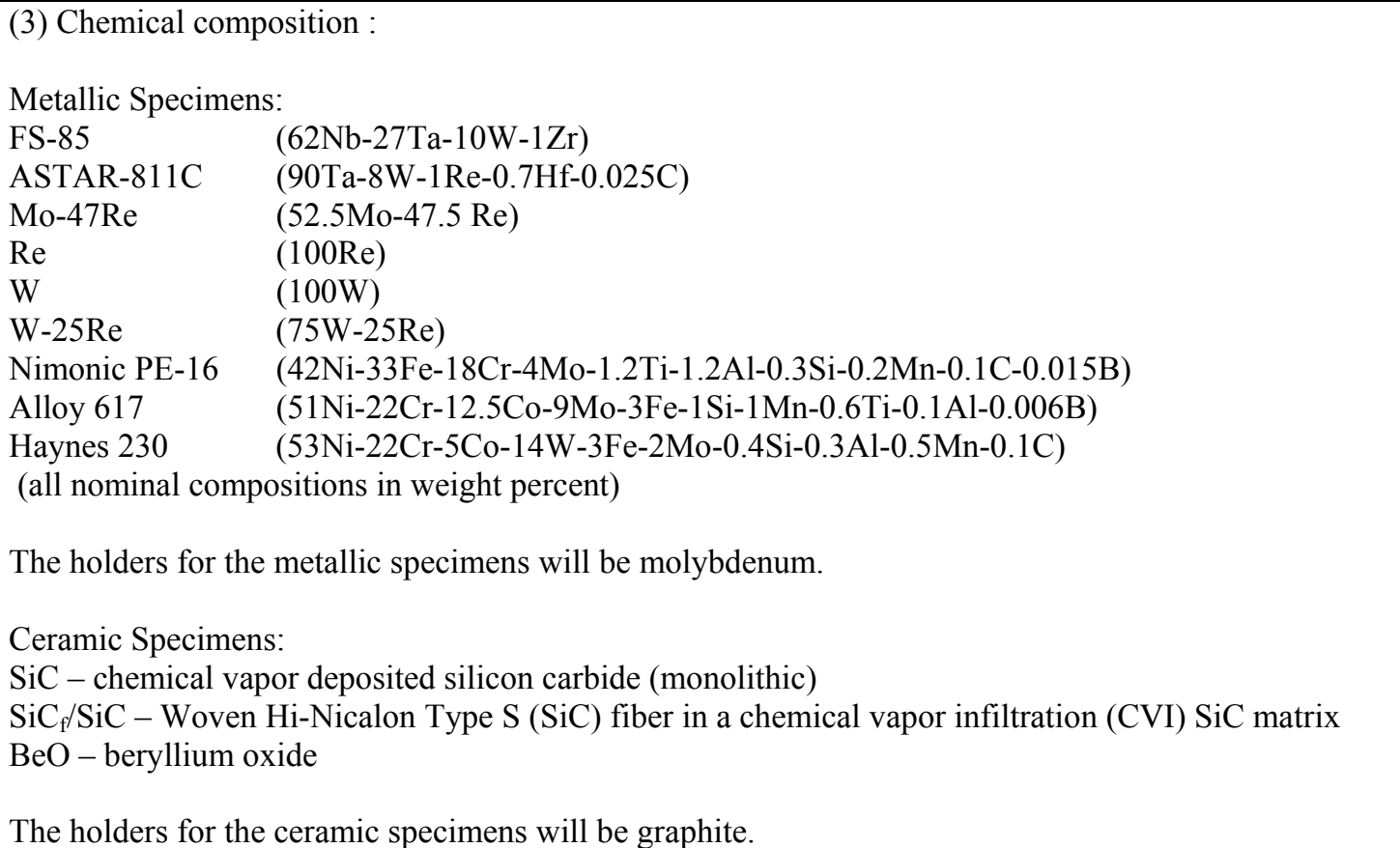 \\
\hline & (4) Physical state : 囚solid or powder, 口liquid, \\
\hline & 冈inorganic compound, $\quad$ arganic compound \\
\hline
\end{tabular}




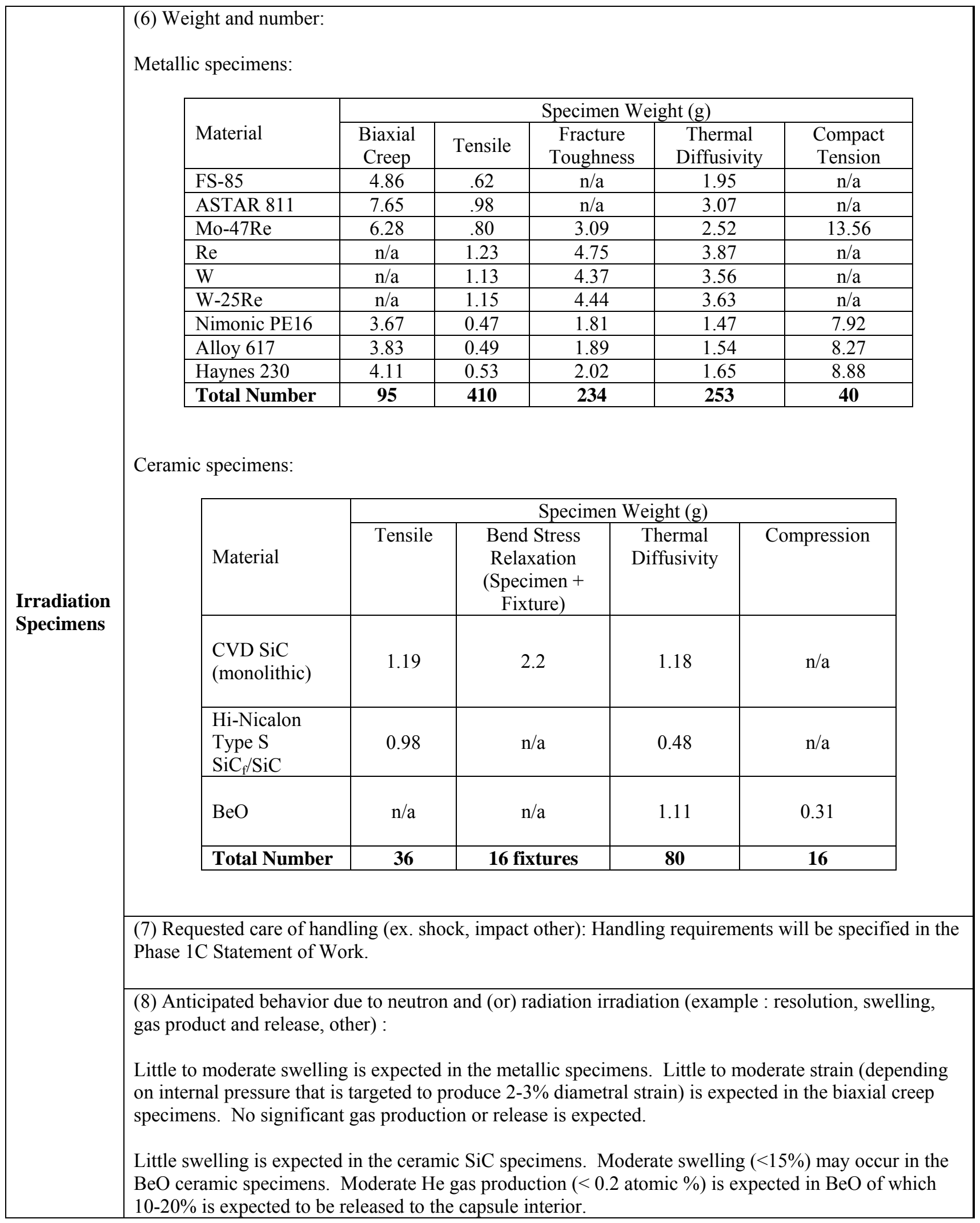




\begin{tabular}{|c|c|}
\hline $\begin{array}{l}\text { Irradiation } \\
\text { Specimens }\end{array}$ & $\begin{array}{l}\text { (9) Anticipated behavior to increase high temperature (example : melting, gas release, other) : } \\
\text { All specimens have significant margin between their desired irradiation temperature and their melting } \\
\text { point. However, exceeding the desired irradiation temperature for prolonged periods ( }>0.1 \mathrm{dpa} \text { ) will } \\
\text { affect the concentration and distribution of irradiation-induced defects, resulting in non-prototypical } \\
\text { swelling conditions. In addition, exceeding the desired irradiation temperature of the biaxial creep } \\
\text { specimens will increase creep rates and could cause specimen failure during irradiation. }\end{array}$ \\
\hline $\begin{array}{l}\text { Irradiation } \\
\text { Conditions }\end{array}$ & $\begin{array}{l}\text { (1) Neutron flux, irradiation time, neutron fluence, damage (dpa): } \\
\text { Rig A (preferred core location 6A4): } 120 \text { days with fast fluence of } 0.1-2.0 \times 10^{22} \mathrm{n} / \mathrm{cm}^{2}(\mathrm{E}>0.1 \mathrm{MeV}) \\
\text { Rig B (preferred core location 6D4): } 60 \text { days with fast fluence of } 0.05-1.0 \times 10^{22} \mathrm{n} / \mathrm{cm}^{2}(\mathrm{E}>0.1 \mathrm{MeV}) \\
\text { (2) Temperature: } \\
\text { For the refractory metals (ASTAR-811C, FS-85, Mo-47Re, Re, W, W-25Re) the desired temperatures } \\
\text { are } 850 \mathrm{~K}, 1100 \mathrm{~K} \text {, and 1350K. } \\
\text { For the Ni-base alloys (Nimonic PE16, Alloy } 617 \text {, Haynes } 230) \text { the desired temperatures are } 850 \mathrm{~K} \text {, } \\
\text { 950K, and 1050K. } \\
\text { For the SiC-based ceramic specimens (SiC, SiC } / \text { SiC) the desired temperatures are } 1100 \mathrm{~K}, 1350 \mathrm{~K} \text {, and } \\
\text { 1470K. } \\
\text { For the BeO ceramic specimens the desired temperatures are } 850 \mathrm{~K} \text { and } 1050 \mathrm{~K} \text {. } \\
\text { (3) Environment: } \square \text { sodium, } \text { gas, } \square \text { other (please describe) } \\
\text { To achieve the high temperatures necessary for the experiment, the capsules will be designed with } \\
\text { appropriate fill gases, gas gaps and Mo or graphite specimen holders to effectively utilize gamma and } \\
\text { neutron heating. The capsule and SMIR loading plans will be specified in the Phase } 1 \mathrm{C} \text { SOW. } \\
\text { (4) Linear heat rate, burn up : Not applicable (structural materials only) }\end{array}$ \\
\hline
\end{tabular}

\begin{tabular}{|c|c|c|}
\hline \multirow{3}{*}{$\begin{array}{l}\text { Scheduling } \\
\text { information }\end{array}$} & $\begin{array}{l}\text { When will specimen be } \\
\text { provided? }\end{array}$ & $\begin{array}{l}\text { To ensure SMIR insertion beginning in JOYO Cycle } 5 \text {, the set of } 60 \\
\text { assembled (sealed) capsules will be provided to JNC no later than } 21 \\
\text { February } 2006 \text {. }\end{array}$ \\
\hline & $\begin{array}{l}\text { Irradiation test desired } \\
\text { dates. }\end{array}$ & $\begin{array}{l}\text { Rig A - JOYO Cycle } 5 \text { and } 6 \text { (both cycles) } \\
\text { Rig B - JOYO Cycle } 5 \text { or } 6 \text { (one cycle only) }\end{array}$ \\
\hline & $\begin{array}{l}\text { Limit date of reporting } \\
\text { irradiation test } \\
\text { information and PIE data. }\end{array}$ & $\begin{array}{l}\text { Irradiation test report : To be determined } \\
\text { PIE report: To be determined }\end{array}$ \\
\hline \multicolumn{3}{|c|}{$\begin{array}{l}\text { How will specimen be handled after irradiation test or (and) PIE : } \\
\quad \square \text { return to user, } \square \text { scrap by JNC, \other (please describe) } \\
\text { Determination of the extent of PIE performed by JNC is still under discussion. Further direction will be provided in } \\
\text { the Phase 1D Statement of Work. }\end{array}$} \\
\hline \multicolumn{2}{|c|}{ Handled specimen number } & $\begin{array}{l}\text { There will be a total of } 1180 \text { specimens in the } 60 \text { sealed capsules that will } \\
\text { be provided to JNC. }\end{array}$ \\
\hline \multicolumn{2}{|c|}{$\begin{array}{l}\text { Maximum radioactivity amount of } \\
\text { handled specimens }(\mathrm{Bq})\end{array}$} & To be determined. \\
\hline
\end{tabular}




\begin{tabular}{|c|c|c|}
\hline \multicolumn{2}{|c|}{ PIE information } \\
\hline \multirow{2}{*}{ PIE content (please describe) } & Quantity & Detail and remark \\
\hline \multirow{2}{*}{ Budget of user's institute } & Total & All PIE plans will be determined at a later date. \\
\hline & $1^{\text {st }}$ year & \\
\hline & $2^{\text {nd }}$ year & $\backslash$ \\
\hline & $3^{\text {rd }}$ year & $\backslash$ \\
\hline \multirow{2}{*}{ Others } & $\begin{array}{l}\text { The budget for each phase of the proposed experiment will be established after receiving formal } \\
\text { responses from JNC to the Phase 1A, 1B, 1C, and 1D Statements of Work. }\end{array}$ \\
\hline
\end{tabular}





\section{Appendix C}

Phase 1A/1B Statement of Work 



\title{
Appendix C. Phase 1A/1B Statement of Work
}

\author{
STATEMENT OF WORK \\ Fabrication of Parts for Structural Materials Irradiation Rigs (SMIRs) \\ for JOYO Irradiation
}

April 28, 2005

\subsection{OBJECTIVE}

To provide work scope and funding to allow the Japan Nuclear Cycle Development Institute (JNC) to procure parts which are needed to assemble two (2) Structural Materials Irradiation Rigs (SMIRs) for future use in the JOYO Experimental Fast Reactor. The goal is to use these 2 irradiation rigs to support irradiation of structural materials in JOYO operation cycle.

\subsection{BACKGROUND}

The procurement of parts for two SMIRs will be funded by Pacific Northwest National Laboratory (PNNL) operated by the Battelle Memorial Institute's, Pacific Northwest Division for the United States Department of Energy. PNNL's customer for this effort, the United States Department of Energy, is developing a civilian space reactor for the National Aeronautics and Space Administration's (NASA) project Prometheus. Battelle (PNNL) is responsible for contracting with JNC for the immediate fabrication of long lead items (i.e., SMIR parts) that will eventually be needed to support assembly of 2 SMIRs. An example of an SMIR is presented in Figure 1. 


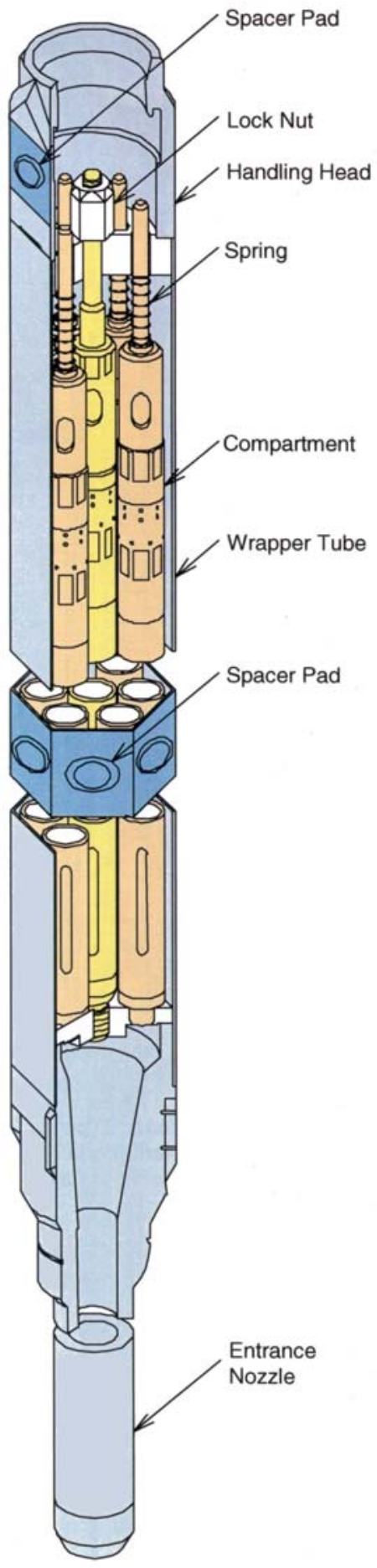

Figure 1, Structural Materials Irradiation Rig (Reference) 


\subsection{WORK SCOPE}

Task $1-$ JNC shall establish contracts to procure a sufficient number of parts for two (2) SMIRs. Task 1 will include the JNC labor to establish and manage the contracts. As a minimum the parts will include:

- Handling Heads

- Wrapper tubes

- Entrance nozzles

- Compartments

NOTE: Upon completion of this work scope, PNNL will not take ownership of these parts. These parts shall be JNC property and shall be considered "consumables" under this contract. However, JNC will guarantee that these parts will only be used for assembly of SMIRs to support irradiation of PNNL and JNC specimens unless otherwise agreed to in writing by both parties.

$\underline{\text { Task } 2}$ - JNC will participate in a design review for permission meeting and host PNNL and several of its customer's design team member at the Oarai Engineering Center. PNNL will provide the following list of information to JNC at least 2 week prior to the design review for permission meeting:

a) List and chemical composition of specimens,

b) Dimension and weight of specimens,

c) List of material and chemical composition for irradiation test capsule, end plugs, and specimen holders,

d) Capsule, end plug, holder, and specimen drawings,

e) Structural calculation report for capsule (including pressure boundaries),

f) Thermal analysis report for capsule (including pressure boundaries),

g) Strength intensity data (Su, Sy) of structural material at normal operating temperature and assumed highest temperature,

h) The coefficients of thermal conductivity and the heat transfer coefficient of each material at normal operating temperature and assumed highest temperature,

i) Welding standard and procedures for capsules,

j) Capsule assembly inspection plan and/or standards,

k) PNNL and JNC will agree any additional content.

JNC desires to have this information sooner than 2 weeks to allow sufficient time for their review. This information will be used by JNC to evaluate worst case bounding scenarios for their design review for permission. JNC will participate in the design 
review meeting for permission. This work scope may be invoiced upon completion of the design review meeting minutes. JNC will also submit a License request to MEXT for the two SMIRs as soon as possible.

$\underline{\text { Task } 3}$ - Receipt of all SMIR parts. Invoices may be submitted as soon as the parts have been properly received by JNC.

\subsection{DELIVERABLES AND SCHEDULE}

Due dates associated with this work scope are as follows:

Deliverable 1: $\quad$ Establish dates for Design Review for Permission
Due Date:
Immediately upon Award

Deliverable 2: $\quad$ Award contracts for SMIR parts.

Due Date: $\quad$ Not later than July 31, 2005

Deliverable 3: $\quad$ JNC participates in design review meeting for permission.

Due Date: $\quad$ On or about June 28, 2005

Deliverable 4: $\quad$ Receipt of all parts for 2 SMIRs.

Due Date: $\quad$ Not later than March 15, 2006

\subsection{QUALITY ASSURANCE REQUIREMENTS}

JNC shall follow all applicable and required Japanese regulatory and internal JNC (JOYO) quality assurance requirements during the procurement of parts for the two SMIRs. No additional or augmented PNNL quality assurance requirements are applicable to these procurements.

\subsection{HOLD AND VERIFICATION POINTS}

PNNL shall be notified when all SMIR parts have been delivered to JNC. PNNL may elect to perform a source verification to assure delivery of all parts, completion of a receiving inspection, and the proper handling and storage of the SMIR parts.

\subsection{INTERFACES}

JNC staff shall interface with the following PNNL personnel or their delegates:

Contracts Doug Akers (509-372-6722)

Technical Chad Painter (509-372-4112) or David Senor (509-376-5610)

Quality Assurance Thomas Hays (509-376-2429)

\section{$\begin{array}{ll}\text { 8.0 REPORTING } & \text { RPR }\end{array}$}


A monthly emailed progress report shall be issued by JNC to PNNL. The progress report shall provide status of progress toward parts procurements and license submittal. The report shall also identify any issues of concern and a description of intended resolution. These reports shall be due to PNNL before the beginning of each month. 



\section{Appendix D}

Phase 1A/1B Contract Agreement 



\section{Appendix D. Agreement for Fabrication of Parts for Structural Materials Irradiation Rigs}

This Agreement is made this $19^{\text {th }}$ day of May, 2005 by and between the following parties (individually a "Party" or collectively the "Parties):

Battelle Memorial Institute ("Battelle") acting through its Pacific Northwest Division, a corporation engaged in the performance of Prime Contract DE-AC05-76RL01830 with the United States Department of Energy (DOE) for the management, operation, and maintenance of the Pacific Northwest National Laboratory (PNNL) and organized and existing under the laws of the State of Ohio, U.S.A, with its principal offices at 902 Battelle Boulevard, Richland WA.

and

Japan Nuclear Cycle Development Institute ("JNC" or "Contractor"), a corporation organized and existing under the laws of Japan, with its principal offices at 4-49, Muramatsu, Tokai-mura, Naka-gun, Ibaragi Prefecture 319-1184, Japan.

The Parties hereby agree as follows:

\section{Engagement}

Battelle hereby engages JNC for fabrication of parts for structural materials irradiation rigs (the "Task") and JNC hereby accepts such engagement, subject to the terms and conditions contained in the following documents ("Contract Documents"):

(1) The Agreement between the Department of Energy of the United States of America and the Japan Nuclear Cycle Development Institute in the Field of Nuclear Technologies dated 22 August, 2000,

(2) This Agreement,

(3) The Statement of Work attached hereto as Exhibit A ( SRM-SOW-001, Rev.1), and

(4) The General Provisions attached hereto as Exhibit B.

\section{Task}

The details of the Task shall be as defined in the Statement of Work (Exhibit A). The Task shall be performed and completed in such manner and at such time as set forth in the Statement of work.

\section{Duration}

The period of performance of the Task shall begin when this Agreement is signed by authorized representatives of JNC and Battelle and shall end on March 31, 2006. 


\title{
4. Contract Price
}

In consideration of the performance of the Task by JNC, Battelle shall pay JNC a fixed amount of JPY 50,003,388.

\section{Payment}

The contract price as set forth in Section 4 hereof shall be paid as follows:

Deliverable 1, Schedule Design Review for Permission Dates

JPY 200,000

Deliverable 2, Award contracts for SMIR parts

JPY 7,700,808

Deliverable 3, Participate in design review meeting for permission

JPY 2,781,600

Deliverable 4, Receipt of all parts for 2 SMIRs

JPY39,320,980

All such payments shall be made in Japanese yen without any deduction by wire transfer to a bank account designated by JNC. All payments shall be made within 30 days of Battelle's receipt of JNC's invoice and proof of deliverables. The final payment shall, assuming all deliverables have been received shall be made by March 31, 2006.

Invoices: Battelle prefers to receive invoices electronically. To ENSURE PROMPT PAYMENT, submit an electronic (PDF, Word, or other format) invoice to Battelle at:

ap.invoices@pnl.gov. Invoices shall be prepared substantially in accordance with the forms listed at www.pnl.gov/contracts/documents/invoices.stm.

If electronic transmittal is not possible, duplicate copies of the invoice and all supporting documentation will be acceptable via mail:

\author{
Battelle, Pacific Northwest Division \\ ATTN: ACCOUNTS PAYABLE \\ P.O. Box 999, MS J1-04 \\ Richland, WA 99352 \\ United States
}

\section{Additional Works}

Following completion of the Task under this Agreement, the Parties intend to enter into further agreements for performance of certain additional works using the structural materials irradiation rigs procured under this Agreement. However, neither Party shall be bound or liable to proceed with any such additional work until and unless an agreement containing the fully agreed terms and conditions for such additional work is executed by both Parties and becomes effective.

\section{General Provisions}

The General Provisions (Exhibit B) shall constitute an integral part of this Agreement and shall apply to the Task hereunder. 


\section{Entire Agreement}

The Contract Documents contain the entire agreement between the Parties and supersede, replace and nullify all prior proposals, agreements, representations and warranties between them, whether written or oral, relating to the subject matter hereof. The Contract Documents may be amended only if agreed to in writing and signed by an authorized representative of each Party.

In Witness Whereof, the Parties have caused this Agreement to be executed by their respective representatives in duplicate.

Battelle Memorial Institute As the operator of Pacific Northwest National Laboratory

Date:

By:

Doug Akers, C.P.M.

Contracting Officer
Japan Nuclear Cycle Development Institute

Date:

By:

Yoshinori OGATA

Director, Technology Management Division 



\section{Appendix E}

\section{Draft Technical Statement of Work for Irradiation Services}





\title{
Appendix E. Draft Statement of Work for Irradiation Services
}

\author{
STATEMENT OF WORK \\ High Temperature Structural Materials Irradiation Test in JOYO \\ (Phase 1C - Irradiation of JOYO-1) \\ August 22, 2005
}

\subsection{OBJECTIVE}

The object of this Statement of Work (SOW) is to specify the various tasks, deliverables, and quality requirements that will be performed by the Japan Atomic Energy Agency (JAEA) in support of the JOYO-1 High Temperature Structural Materials Irradiation Test program. The activities specified in this SOW are summarized as follows:

- Receipt of test capsule shipment,

- Review of the capsule assembly certification package,

- Participation in a trial shipment of dummy capsules for the purpose of verifying an adequate shipping process,

- Application for an Export License so that future technical data can be provided to PNNL (e.g., Irradiation Test Report, future PIE results and technical support data as required by the NRPCT in support of this program),

- Detailed calculations of capsule and specimen radioactivity to support PIE and capsule handling after irradiation,

- Receipt and inspection of 70 (60 plus 10 spares) NRPCT test capsules. Spares will be solid steel and intended as backups,

- Final assembly and loading of capsules into 2 Structural Materials Irradiation Test Rigs (SMIRs),

- Insertion of SMIRs into the JOYO reactor in predetermined locations,

- Irradiation of NRPCT capsules in JOYO cycles 5 and 6 and preparation of a Irradiation Test Report,

- Extraction of SMIRs from the JOYO reactor after irradiation, removal of the capsules from the SMIRs, and limited inspections,

- Final disposal of the irradiation rig hardware owned by JAEA, and

- Overall management of these various efforts.

Additionally, as an optional task that may be executed by PNNL, as agreed to by JAEA, after the contract award, JAEA shall provide a fixed cost for:

1. Efforts required to obtain government approvals to ship irradiated materials in support of this program to the United States. This plan is not necessarily limited to the use of the TN6-4 cask, and

2. Obtain a US Department of Transportation license for a cask to allow shipment of irradiated materials to the United Statues. 


\subsection{BACKGROUND}

The scope described in this SOW will be funded and monitored by Pacific Northwest National Laboratory (PNNL) which is operated by the Battelle Memorial Institute's, Pacific Northwest Division for the United States Department of Energy. PNNL's customer for this effort, the United States Department of Energy, is developing a civilian space reactor for the National Aeronautics and Space Administration's (NASA) Project Prometheus.

Sixty capsules containing high temperature structural materials will be provided to JAEA for irradiation in JOYO Cycles 5 and/or 6. This effort will be referred to as the JOYO-1 campaign. The test specimens and capsules will be designed by the Naval Reactors Prime Contractor Team (NRPCT). The capsules will be assembled, welded, inspected, tested and certified by the NRPCT. All assembly, welding, inspection, testing and certifications will be conducted at NRPCT facilities in Pittsburgh, PA. PNNL is responsible for ensure that all US export control laws are met and will arrange for shipping of the assembled and certified test capsules to JAEA. Additionally, PNNL is providing design analysis support to NRPCT and will weld and pressurize the biaxial creep specimens for the JOYO-1 irradiation. Disassembly of the capsules and postirradiation examination of the specimens will be conducted under a separate SOW to be issued and contracted at a later date. The ultimate goal of this program is to provide post irradiation examination results on the high temperature structural materials in FY08.

\subsection{WORK SCOPE}

This section describes each of the various tasks that need to be accomplished as part of this phase of work.

Task 2 - NRPCT will certify in writing that the test capsules were assembled in accordance with applicable NRPCT capsule assembly procedures. JAEA will review the NRPCT's capsule assembly certification package. The content of the capsule certification package will include:

- Written certification that the capsules were assembled per NRPCT assembly plans,

- Capsule design drawings,

- Assembly Procedures (Route Cards) that include:

o Visual and Dimensional inspection results

o Liquid penetrant and pressure \& helium leak test results

- Material certifications for capsules bodies and end caps, specimens, and specimen holders,

- Photographs of the capsule assembly process,

- Substitution of specimens as identified in the Design for Permission Report will be documented in the capsule certification.

A summary of the capsule assembly process is included in Figure 1. Photographs of the various assembly steps will be provided to JAEA as a pictorial sequence of operations.

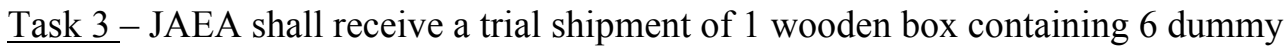


capsules with accelerometers. A $30 \mathrm{G}$ and $50 \mathrm{G}$ accelerometer will be mounted on one dummy capsule and a 20G, $30 \mathrm{G}$, and two $50 \mathrm{G}$ accelerometers will be located within cushioning material used to protect the capsules. Instructions for evaluating the accelerometers will be provided in the trial shipment. Any unused capsules not utilized in the JOYO-1 test program shall be returned to PNNL.

Task 4 - JAEA shall obtain an Export License to allow export of technical data that will be included in a Irradiation Test Report and future PIE results or data needed to support future structural or material testing in JOYO. Technical information will be needed to support future capsule designs. In order for this to task to be completed it is possible that the US Department of State may need to exchange a verbal note with the Ministry of Foreign Affairs (MOFA) in Japan confirming peaceful uses related to this project. JAEA will file an application for service transaction with Japan's Ministry of Economy, Trade and Industry (METI). After the exchange of verbal notes between US DOS and MOFA, METI will be able to issue an export license to JAEA.

Task 5 - JAEA shall prepare detailed calculations to predict the radioactivity and heat loads associated with capsule materials, specimen holders, and specimens to support capsule handling after irradiation and eventual PIE. Based on the results of the detailed calculations, JAEA will review and make changes to existing facility documentation to ensure that the irradiated NPRCT capsules and materials can be safely handed in the Fuels Monitoring Facility (FMF).

Task 6 - JAEA shall receive 70 assembled capsules from PNNL. Sixty of these capsules will be loaded into the JOYO reactor. The additional 10 capsules are solid steel dummy replacement capsules in the event some are damages during shipment. A documented receipt inspection by JAEA personnel shall be performed. The contents of the capsules and the composition, density, and mass of the test specimens, specimen holders, internal capsule hardware and capsule bodies are listed in Attachment A. Additional relevant details regarding the specimen and capsule design may be found in the JOYO-1 Design for Permission Report (B-MT(EDT)S-014) previously submitted to JAEA by PNNL on behalf of NRPCT.

PNNL will provide required capsule handling requirements at least 30 days prior to shipment to JAEA. Capsules containing test specimens will be shipped in packages containing accelerometers. Instructions pertaining to inspection of the accelerometers will be included in the shipment.

A source verification will be performed by PNNL during the JAEA receiving inspection to observe the condition of the shipping containers, capsules and the condition/state of the accelerometers. In the event the accelerometers are determined to have exceeded the maximum allowable g-force loading, JAEA shall document and forward the condition to PNNL in accordance with their nonconformance procedure. Those capsules in shipping containers with tripped accelerometers shall be tagged and segregated from the remainder of the capsules.

JAEA will radiograph only the 60 capsules with internal specimens after receipt inspections are completed. The 10 solid steel replacement capsules do not need to be radiographed. NRPCT will provide JAEA with guidance on capsule radiography parameters to assist with inspection setup based on NRPCT experience in radiographing 
capsules. JAEA can use the capsules in the trail shipment to develop parameters, if warranted. The information will be provided not later than December $10^{\text {th }}, 2005$.

In the event of tripped accelerometers results of the radiography will be reviewed concurrently by JAEA, PNNL, and NRPCT to determine an appropriate disposition.

Task 7 - JAEA shall assemble two (2) SMIRs in accordance with approved internal JAEA design documents and quality assurance plans and procedures. The 60 selected capsules shall be loaded into the SMIRs per the SMIR loading diagram shown in Attachment B. A source verification shall be performed by PNNL during capsule loading to verify compliance with the loading diagram. In the event that some capsules are damaged during shipment or planned materials were not available in time to support the JOYO-1 irradiation campaign a substitution plan is presented in Attachment $\mathrm{C}$. The substitute plan will allow for substitution of capsules within the loading plan.

Photographs of the SMIR assembly process shall be performed and submitted to PNNL.

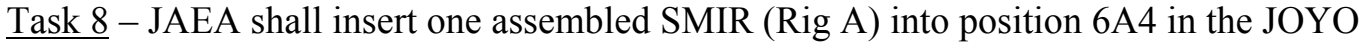
reactor. Rig A will remain in the JOYO reactor for both Cycles 5 and 6. JAEA shall insert the other assembled SMIR (Rig B) into position 6D4 in the JOYO reactor. Rig B will remain in the JOYO reactor for only Cycle 5. Target irradiation conditions are provided in the Experiment Proposal Form, "Irradiation of Structural Materials for Prometheus 1 Space Reactor" submitted to JAEA by PNNL on behalf of NRPCT on August xx, 2005.

Task 9 - JAEA shall irradiate NRPCT capsules and provide an Irradiation Test Report following the end of JOYO Cycle 6 that includes the following data:

o Power history for JOYO Cycles 5 and 6,

o Core inlet and outlet temperature history for JOYO Cycles 5 and 6,

o Core sodium flowrate history for JOYO Cycles 5 and 6,

o Nuclear analysis (flux and fluence calculations) to support future dosimetry,

o Unexpected events and/or shutdowns.

Task 10 - JAEA shall remove Rig B from JOYO after Cycle 5. JAEA shall remove Rig A from JOYO after Cycle 6. JAEA shall perform x-ray tomography in an alpha clean cell to provide an initial indication of how the various specimens may have performed in the reactor. X-ray tomography shall be performed on each rig. Cross sections views showing the 6 compartments shall be taken at 15 axial locations, thus providing approximately 3 cross sections in each capsule tier. Specific locations will be provided at a later date.

JAEA shall disassemble the SMIRs and remove the capsules. It is desired that a PNNL technical representative observe a portion of the disassembly to assess the condition of the capsules. JAEA shall provide a written summary describing the condition of each capsule after SMIR disassembly, including weights, circumferential and axial profilometry, and photographs.

The capsules shall be staged and made ready for the next phase of capsule disassembly and/or shipment back to the United States. Additional post-irradiation examinations (PIE) will be performed under a separate SOW. 
Task 11 - JAEA shall dispose of all irradiated SMIR hardware, including spacers, unless these components can be reused by JAEA.

Task 12 - JAEA shall manage all the above activities and participate in periodic email exchanges and conference calls. JAEA shall provide a monthly written status report. The status report should provide a summary of progress toward SMIR fabrication, upcoming inspection/verification hold points, capsule receipt and loading, SMIR insertion in the core, JOYO status while the SMIRs are in the core, SMIR removal from the core, SMIR disassembly, and SMIR hardware disposal. The report shall also identify any issues of concern and proposed resolution. Status reports are due no later than the $5^{\text {th }}$ of each month describing activities in the previous month.

Additionally, JAEA shall provide a per page fixed cost for translation of JAEA documents. Any documents that are requested by PNNL to be translated can then be invoiced on a per page basis.

PNNL shall be responsible for contracting for all necessary interpretation services.

Task 13 (OPTIONAL negotiated task to be executed at a later date) - JAEA shall provide technical, quality and project management services to gain approval by the Japanese government for shipping irradiated NRPCT materials. This task will include all analyses required to support the approval process and management and oversight of any necessary subcontracts.

Additionally, JAEA shall seek and obtain a US Department of Transportation license for the cask to be used. This effort will be limited to submittal of an application and analyses necessary to support a licensing effort. Any hardware design and modifications that may be needed to obtain a license will be agreed to under a separate contract or modification to this contract. The cost for cask shipment(s) of irradiated NRPCT materials to the US will also be agreed to under a separate contract or modification to this contract.

\subsection{QUALITY ASSURANCE REQUIREMENTS}

JAEA shall implement the current revision of the JAEA Quality Assurance Programs including; Oarai Engineering Center Quality Assurance Program (17OEC Rule No. April 1, 2005), Irradiation Center Quality Assurance Program and specific SMIR assembly and capsule loading Production and Quality Control Manual(s) for work described in this Statement of Work.

In addition, the following specific quality assurance requirements are applied to this effort and shall be addressed and implemented by JAEA.

1) JAEA shall maintain and implement the referenced QA Programs and manuals and ensure that all work meets contract requirements.

2) JAEA shall notify PNNL in writing if referenced Quality Assurance Programs and manuals are revised, other than editorial revisions.

3) All documents and referenced data for this contract shall be available for review by PNNL to determine compliance with the requirements for control of the work. English 
translation of documents, if required, will be paid for on a per page basis as part of Task 12. Transmittal of documents will be subject to export control requirements.

4) Any nonconforming condition and corrective action that affects the capsules or irradiation activity shall be documented and transmitted to PNNL. JAEA shall coordinate corrective actions with PNNL.

5) JAEA shall repeat any reasonably requested measurement, inspection or test as requested by PNNL to substantiate compliance as agreed to by JAEA.

6) Required final acceptance inspections and testing by JAEA shall be performed by personnel qualified, and as applicable, certified in accordance with JAEA Quality Assurance Program requirements. JAEA shall maintain for review all procedures and adequate documentation to substantiate initial and continued qualification and certification of inspection and test personnel and provide access for review of documentation by PNNL.

7) If JAEA utilizes any lower-tier suppliers for work under this Contract, JAEA shall implement procurement controls in accordance with the JAEA Quality Programs to assure that all purchased materials, equipment and services that are quality affecting will conform to order requirements. Specific procurement controls shall include:

- Selection of qualified suppliers,

- Pass down of salient order requirements,

- Quality surveillance process and product verification of procured items, and

- Effective information feedback and correction of non-conforming conditions.

8) JAEA shall utilize required and appropriate measuring and test equipment (M\&TE). JAEA shall control and calibrate M\&TE in accordance with JAEA Quality Assurance Program. JAEA shall maintain adequate documentation to substantiate M\&TE control and provide access for review of documentation by PNNL. Specific M\&TE controls shall include:

- Appropriate standards used which are traceable to recognized international and/or Japanese standards.

- Standards established by JAEA for calibrating the measuring and test equipment used shall have the capabilities for accuracy, stability, and range for intended use.

9) JAEA shall maintain all records that substantiate Contract compliance. Records shall be protected from loss, deterioration, or damage. Records shall be transmitted to PNNL as detailed in this SOW. JAEA shall maintain records as required by internal and regulatory requirements.

10) All required inspection and test data shall be legibly recorded and shall be traceable to this Contract. Inspection and test data documentation shall be made available for review by PNNL. The following information, including all JAEA required inspection and test elements shall be considered for inclusion:

- Reference to applicable design documents and revision level,

- Reference to item inspected or tested and serial numbers or traceability numbers,

- Date of inspection or test,

- Material qualification compliance 
- Temperature of items when dimensional inspection are performed

- Identification of any nonconforming condition and traceability to PNNL concurrence, as applicable,

- Results of acceptability

- Signature and qualification/certification level of personnel who performed inspection/test.

11) JAEA facilities, personnel, equipment, and documentation associated with this work shall be subject to observation, in-process surveillance, and/or source

verification/inspection by PNNL, NRPCT, and/or other U.S. DOE Representatives at no additional cost. JAEA will receive at least 14 calendar days advance notification of the planned date for any observation, in-process surveillance or source verification/inspection. As requested, JAEA personnel shall be made available for operation of measuring and test equipment for verification of their accuracy and condition.

12) Various steps on this order are subject to Mandatory verification/inspection Hold Points and/or Source verifications by PNNL and/or NRPCT. Refer to section 6.0 for a list of mandatory hold points and notification requirements.

When Source Inspection or other inspections are required, work shall not proceed beyond the inspection point until released by PNNL. This release may be provided at the time of the Source Inspection.

13) JAEA shall provide written certification of compliance for receipt inspection, handling/storage/protection of capsules, placement of capsules in SMIR and placement of irradiation rigs into the JOYO reactor. The certification shall contain the following information and shall be submitted to PNNL on JAEA letterhead:

- JAEA's name and address,

- Purchase order number.

- Listing of key design or regulatory documents met including approved design change documents,

- Listing of any unresolved nonconforming items or noncompliance to Contract requirements, and

- Name and signature of certifying authority.

14) JAEA shall certify conformance to all Contract requirements via Certificate of Conformance. Certification shall be based on a formal review by appropriate JAEA personnel based on verification of compliance to requirements. When requested by PNNL, JAEA shall furnish objective evidence substantiating submitted Certificate of Conformance.

15) JAEA shall certify that there was no substitution of furnished items and components in completing the work and that such furnished items and components were used as required.

16) If it is determined that JAEA return for any reason to PNNL any items, JAEA shall certify that no changes have occurred. If any changes did occur changes must be clearly described. Include in the certificate with returned items: Quantity, description, and 
identification or control number. If changed, a description of the process used and reference to action that approved the change.

17) Three copies (translated to English) of each type of documentation required by this SOW shall be supplied to PNNL. One copy will be provided to PNNL personnel during source verifications and two copies will be mailed to PNNL.

\subsection{DELIVERABLES AND SCHEDULE}

The following deliverables shall be provided to PNNL at the established due dates for each task in Section 3.0. Deliverables associated with Quality Assurance requirements are also defined in this section.

Deliverable 1-1: $\quad$ Receive test capsule shipment.

Due Date: Not later than December 15, 2005

Deliverable 1-2: $\quad$ Provide comments to biaxial creep certification package

Due Date: Note later than November 15, 2005

Deliverable 2: $\quad$ JAEA shall complete review of the Capsule Assembly certification package.

Due Date: Not later than 15 business days after the certification package is submitted.

Deliverable 3: $\quad$ JAEA receive trial shipment of dummy capsules and inspect accelerometers.

Due Date: Upon receipt of trial shipment, tentatively planned for mid December 2005.

Deliverable 4: $\quad$ JAEA obtain Export Control License for shipping of DOE owned materials to PNNL, and forwarding technical data and reports.

Due Date: Not later than October 2006

Deliverable 5: $\quad$ JAEA shall provide results of detailed analysis of radioactivity and heat loading. And ensure FMF is ready to handle irradiated NRPCT capsules and specimens.

Due Date: Not later than February 2006

Deliverable 6-1: $\quad$ JAEA shall provide a written Receiving Inspection Report after completing a receiving inspection on the sealed capsules.

Due Date: Ten (10) business days after receipt of capsules. 
Deliverable 6-2: $\quad$ JAEA shall provide copies of the developed X-ray film, or digital images of the X-ray film, associated with the preirradiation X-ray radiography of each capsule received NRPCT capsule. [Note: this does not include the solid steel replacement capsules.]

Due Date: Twenty (20) business days after completion of radiography.

Deliverable 7-1: JAEA shall provide an English translated version for PNNL review of a Production and Quality Control Manual describing the SMIR assembly and capsule loading process.

Due Date: Twenty (20) business days prior to insertion of capsules in SMIR

Deliverable 7-2: $\quad$ JAEA shall provide written notice to PNNL prior to beginning capsule loading into the first SMIR.

Due Date: A tentative date will be provided at least forty-five (45) calendar days before beginning capsule loading in the first SMIR. At least 15 days prior to loading a firm date will be provided so that travel arrangements can be made by PNNL.

Deliverable 7-3: $\quad$ JAEA shall load and assemble 2 SMIRs and provide written notice that this work has been completed. JAEA shall provide photographs of the SMIR assembly.

Due Date: Loading shall occur In sufficient time to support JOYO Cycle 5 and 6 . Photographs shall be delivered to PNNL 30 days after SMIR assembly.

Deliverable 8: $\quad$ JAEA shall certify in writing the location of each rig as loaded into the JOYO reactor.

Due Date: Twenty business days after loading.

Deliverable 9-1: $\quad$ JAEA irradiation of 60 NRPCT capsules in the JOYO reactor. Rig A (6A4) to be irradiated for cycle 5 and 6 and Rig B (6D4) to be irradiated in cycle 5 (neutron fee).

Due Date: About November 2006.

Deliverable 9-2: $\quad$ JAEA shall provide an Irradiation Test Report

Due Date: Forty (40) business days after the end of JOYO Cycle 6

Deliverable 10-1: $\quad$ JAEA shall provide written notice to PNNL prior to beginning SMIR disassembly after irradiation 
Due Date: Forty-five (45) calendar days before beginning SMIR disassembly and capsule extraction

Deliverable 10-2: JAEA shall provide a written summary describing the condition of the capsules after SMIR disassembly, including weights, dimensions, axial profilometry, photographs and x-ray tomography results.

Due Date: Thirty (30) calendar days after completing all inspections

Deliverable 10-3: $\quad$ JAEA shall dispose of SMIR hardware and spacers.

Due Date: Expenses associated with this deliverable shall be billed not later than 3 years after award of contract.

Deliverable 12-1: JAEA shall submit monthly written status reports in English.

Due Date: Monthly, no later than the $5^{\text {th }}$ of each month

Deliverable 12-2: $\quad$ JAEA may submit invoices for project management expenses on a monthly, quarterly or annual basis.

Due Date: Monthly, quarterly, or annually.

Deliverable 12-3: $\quad$ Document translation services as required.

Due Date: As necessary.

Deliverable 13: $\quad$ (OPTIONAL TASK) Obtain Japanese government to use JAEA cask to ship irradiated NRPCT materials. Obtain a US Department of Transportation license for a shipping cask.

Due Date: To be determined upon authorization of this task.

Deliverable QA-2: $\quad$ Notify PNNL if QA program is revised.

Due Date: 20 calendar days prior to implementation.

Deliverable QA-4 Notify PNNL of any nonconforming condition. Submit copy of Nonconformance Report.

Due Date: 5 calendar days after discovery and/or documentation of nonconformance.

Deliverable QA-17 JAEA shall provide specific written certification for following: 
- Receipt inspection,

- Handling/storage/protection of capsules,

- Placement of capsules in the SMIRs, and

- Placement of the rigs into the JOYO reactor.

Due Date: 20 calendar days after placement of rigs into JOYO.

Deliverable QA-20

QA-21, QA-22,
JAEA shall provide written Certificate of Conformance for:

- No substitutions of furnished products

- No changes to furnished products

Due Date: At the conclusion of work required under this SOW.

\subsection{HOLD POINTS AND TECHNICAL OVERSIGHT}

Hold Points - PNNL requires the following mandatory hold points:

1. During receipt of NRPCT capsules by JAEA to verify the condition of the capsules.

2. PNNL will perform a verification during capsule loading into the SMIRs to verify proper capsule placement into the various rigs, compartments, and tiers.

Technical Oversight - It is desired that a PNNL technical representative observe a portion of the removal of capsules from the SMIRs after irradiation to view capsule condition.

\subsection{INTERFACES}

JAEA staff shall interface with the following PNNL personnel or their delegates:

Contracts - $\quad$ Doug Akers (doug.akers@pnl.gov 509-372-6722)

PNNL Technical - _ David Senor (david.senor@pnl.gov 509-376-5610 or Chad

Painter

(chad.painter@pnl.gov 509-372-4112)

NRPCT Technical - George Newsome (newsome@kapl.gov; 518 395-7364) and

Bill Saylor (saylorws@bettis.gov 412-476-5859)

Quality Assurance - Thomas Hays (thomas.hays@pnl.gov 509-376-2429)

All final JAEA submittals shall be sent to the following address:

Pacific Northwest National Laboratory

Attn: Doug Akers MS/K7-02

902 Battelle Boulevard

Richland, WA 99352

All changes to work scope and cost must be agreed to in writing. 


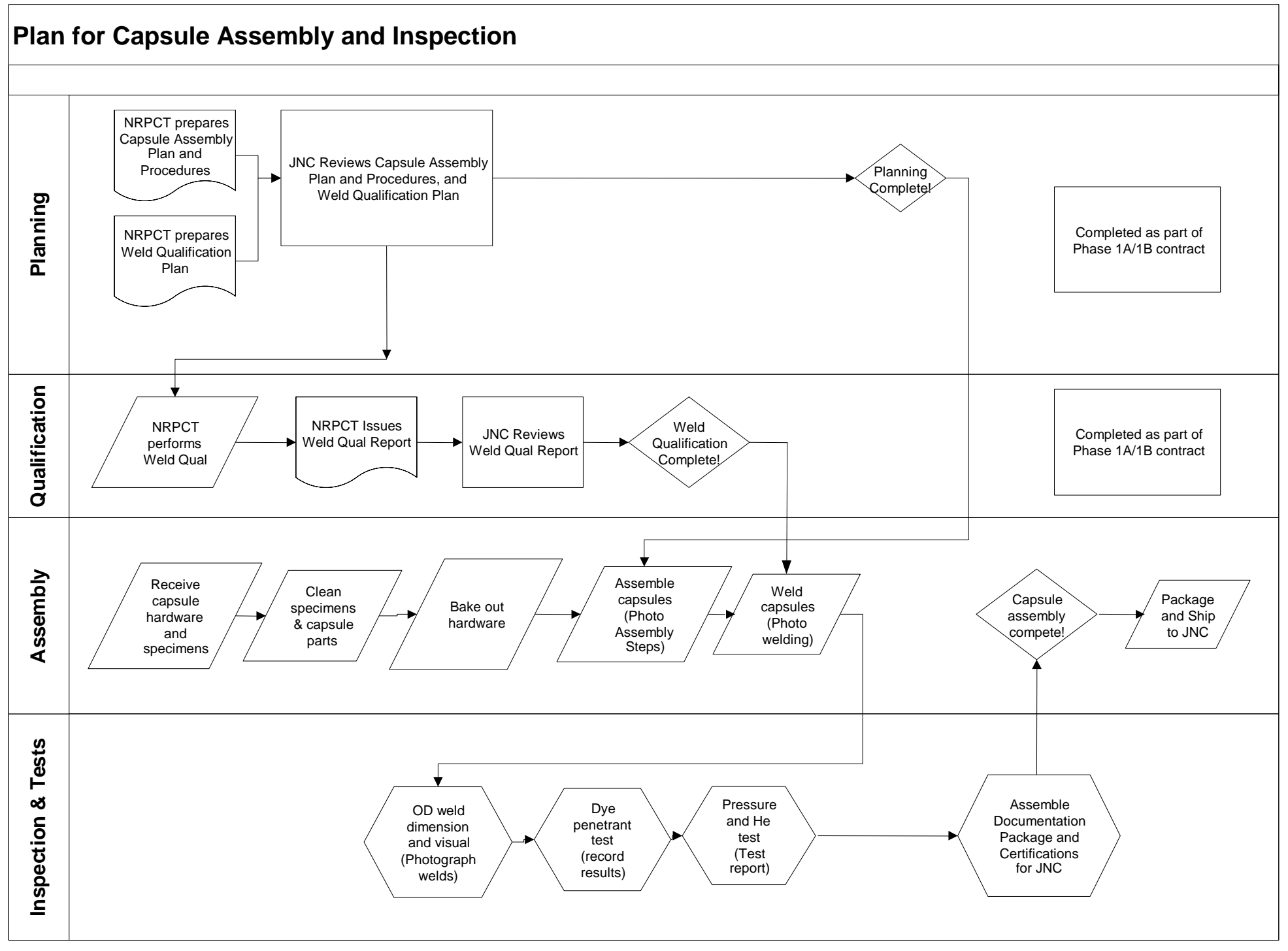

Figure 1. Capsule Assembly and Inspection Plan 


\title{
Attachment A
}

Technical Data on Specimens, Specimen Holders, Capsule Internal Hardware and Capsule Bodies

\section{Metallic Specimen Composition*}

\author{
FS-85 (62Nb-27Ta-10W-1Zr) \\ ASTAR-811C (90Ta-8W-1Re-0.7Hf-0.025C) \\ Mo-47Re (52.5Mo-47.5 Re) \\ Re $\quad(100 \mathrm{Re})$ \\ $\mathrm{W} \quad(100 \mathrm{~W})$ \\ $\mathrm{W}-25 \mathrm{Re} \quad(75 \mathrm{~W}-25 \mathrm{Re})$ \\ Nimonic PE-16 (42Ni-33Fe-18Cr-4Mo-1.2Ti-1.2Al-0.3Si-0.2Mn-0.1C-0.015B) \\ Alloy $617 \quad$ (51Ni-22Cr-12.5Co-9Mo-3Fe-1Si-1Mn-0.6Ti-0.1 Al-0.006B) \\ Haynes $230 \quad$ (53Ni-22Cr-5Co-14W-3Fe-2Mo-0.4Si-0.3Al-0.5Mn-0.1C) \\ *(all nominal compositions in weight percent)
}

Table A.1. Shape, dimensions, volume and number of metallic specimens

\begin{tabular}{|c|c|c|c|c|}
\hline Specimen Type & Shape & Size (mm) & $\begin{array}{c}\text { Volume } \\
\left(\mathrm{mm}^{3}\right)\end{array}$ & $\begin{array}{l}\text { Number of } \\
\text { Specimens }\end{array}$ \\
\hline Biaxial creep & $\begin{array}{c}\text { Circular } \\
\text { cylinder, } \\
\text { pressurized tube }\end{array}$ & $\begin{array}{l}6.25 \text { diameter } \mathrm{x} \\
33 \text { long }\end{array}$ & 458 & 95 \\
\hline Tensile & $\begin{array}{l}\text { Rectangular, } \\
\text { dog bone } \\
\text { shaped, flat }\end{array}$ & $\begin{array}{c}5 \text { wide } \times 25.4 \\
\text { long } \times 0.75 \\
\text { thick }\end{array}$ & 59 & 410 \\
\hline Fracture toughness & $\begin{array}{l}\text { Single-edge } \\
\text { notched bars }\end{array}$ & $\begin{array}{l}3 \text { wide } \times 25.4 \\
\text { long } \times 3 \text { thick }\end{array}$ & 226 & 234 \\
\hline Thermal diffusivity & $\begin{array}{c}\text { Circular } \\
\text { cylinder disks }\end{array}$ & $\begin{array}{l}\text { 12.5 diameter } \mathrm{x} \\
1.5 \text { thick }\end{array}$ & 184 & 253 \\
\hline $\begin{array}{l}\text { Compact Tension (bolt } \\
\text { that will be included not } \\
\text { shown in figure) }\end{array}$ & $\begin{array}{c}\text { Notched } \\
\text { Circular Disk }\end{array}$ & $\begin{array}{l}15 \text { diameter } \mathrm{x} \\
5.6 \text { thick }\end{array}$ & 840 & 40 \\
\hline
\end{tabular}


Table A.2. Density and mass of metallic specimens

\begin{tabular}{|c|c|c|c|c|c|c|}
\hline \multirow[b]{2}{*}{ Material } & \multirow[b]{2}{*}{$\begin{array}{l}\text { Density } \\
\left(\mathrm{g} / \mathrm{cm}^{3}\right)\end{array}$} & \multicolumn{5}{|c|}{ Specimen Weight (g) } \\
\hline & & $\begin{array}{c}\text { Biaxial } \\
\text { Creep }\end{array}$ & Tensile & $\begin{array}{c}\text { Fracture } \\
\text { Toughness }\end{array}$ & $\begin{array}{l}\text { Thermal } \\
\text { Diffusivity }\end{array}$ & $\begin{array}{c}\text { Compact } \\
\text { Tension }\end{array}$ \\
\hline FS-85 & 10.6 & 4.86 & .62 & $\mathrm{n} / \mathrm{a}$ & 1.95 & $\mathrm{n} / \mathrm{a}$ \\
\hline ASTAR 811 & 16.7 & 7.65 & .98 & $\mathrm{n} / \mathrm{a}$ & 3.07 & $\mathrm{n} / \mathrm{a}$ \\
\hline Mo-47Re & 13.7 & 6.28 & .80 & 3.09 & 2.52 & 13.56 \\
\hline $\operatorname{Re}$ & 21.04 & $\mathrm{n} / \mathrm{a}$ & 1.23 & 4.75 & 3.87 & $\mathrm{n} / \mathrm{a}$ \\
\hline $\mathrm{W}$ & 19.35 & $\mathrm{n} / \mathrm{a}$ & 1.13 & 4.37 & 3.56 & $\mathrm{n} / \mathrm{a}$ \\
\hline $\mathrm{W}-25 \mathrm{Re}$ & 19.7 & $\mathrm{n} / \mathrm{a}$ & 1.15 & 4.44 & 3.63 & $\mathrm{n} / \mathrm{a}$ \\
\hline Nimonic PE16 & 8.0 & 3.67 & 0.47 & 1.81 & 1.47 & 7.92 \\
\hline Alloy 617 & 8.36 & 3.83 & 0.49 & 1.89 & 1.54 & 8.27 \\
\hline Haynes 230 & 8.97 & 4.11 & 0.53 & 2.02 & 1.65 & 8.88 \\
\hline
\end{tabular}




\section{Ceramic specimen composition}

$\mathrm{SiC}$ - Chemical vapor deposited silicon carbide (monolithic)

$\mathrm{SiC}_{\mathrm{f}} / \mathrm{SiC}-$ Woven Hi-Nicalon Type $\mathrm{S}(\mathrm{SiC})$ fiber in a chemical vapor infiltration (CVI) $\mathrm{SiC}$ matrix

$\mathrm{BeO}$ - Beryllium oxide

Table A.3. Shape dimension, volume and number of ceramic specimens

\begin{tabular}{|c|c|c|c|c|}
\hline Specimen Type & Shape & Size (mm) & $\begin{array}{l}\text { Volume } \\
\left(\mathrm{mm}^{3}\right)\end{array}$ & $\begin{array}{l}\text { Number of } \\
\text { Specimens }\end{array}$ \\
\hline Tensile & $\begin{array}{l}\text { Rectangular, } \\
\text { dog bone } \\
\text { shaped, flat }\end{array}$ & $\begin{array}{c}6 \text { wide } \times 41.3 \\
\text { long } \times 2.3 \text { thick }\end{array}$ & 372 & 36 \\
\hline $\begin{array}{l}\text { Composite Thermal } \\
\text { Conductivity }\end{array}$ & $\begin{array}{c}\text { Circular } \\
\text { cylinder disks }\end{array}$ & $\begin{array}{l}12.5 \text { diameter } \mathrm{x} \\
1.5 \text { thick }\end{array}$ & 184 & 24 \\
\hline Thermal Conductivity & $\begin{array}{c}\text { Circular } \\
\text { cylinder disks }\end{array}$ & $\begin{array}{l}12.5 \text { diameter } \mathrm{x} \\
3 \text { thick }\end{array}$ & 368 & 24 \\
\hline BeO Density Disk & $\begin{array}{c}\text { Circular } \\
\text { cylinder disks }\end{array}$ & $\begin{array}{l}12.5 \text { diameter } \mathrm{x} \\
3 \text { thick }\end{array}$ & 368 & 32 \\
\hline BeO Compression & $\begin{array}{c}\text { Circular } \\
\text { cylinder disks }\end{array}$ & $\begin{array}{l}4 \text { diameter } \mathrm{x} \\
8 \text { tall }\end{array}$ & 100 & 16 \\
\hline Ceramic Strip & $\begin{array}{c}\text { Thin } \\
\text { Rectangular } \\
\text { Strips } \\
\text { (up to } 3 \text { strips } \\
\text { per fixture) }\end{array}$ & $\begin{array}{c}.05, .1, .2 \text { wide } \\
\text { x } 25 \text { long } \\
\text { (specimen) } \\
6.4 \text { wide } \times 50 \\
\text { long } 52 \text { thick } \\
\text { (fixture) }\end{array}$ & $\begin{array}{c}1.3,2.6,5.2 \\
\text { (specimen) } \\
626 \\
\text { (fixture) }\end{array}$ & $\begin{array}{c}16 \\
\text { fixtures }\end{array}$ \\
\hline
\end{tabular}


Table A.4. Density and mass of ceramic specimens

\begin{tabular}{|c|c|c|c|c|c|}
\hline \multirow{2}{*}{ Material } & \multirow{2}{*}{$\begin{array}{c}\text { Density } \\
\left(\mathbf{g} / \mathbf{c m}^{3}\right)\end{array}$} & Tensile & $\begin{array}{c}\text { Bend Stress } \\
\text { Relaxation }\end{array}$ & $\begin{array}{c}\text { Thermal } \\
\text { Diffusivity }\end{array}$ & Compression \\
\hline $\begin{array}{c}\text { CVD SiC } \\
\text { (monolithic) }\end{array}$ & 3.2 & 1.19 & $\begin{array}{c}2.2 \text { (fixture \& } \\
\text { specimens) }\end{array}$ & 1.18 & $\mathrm{n} / \mathrm{a}$ \\
\hline $\begin{array}{c}\text { Hi-Nicalon } \\
\text { Type S } \\
\mathrm{SiC} / \mathrm{SiC}\end{array}$ & 2.6 & 0.98 & $\mathrm{n} / \mathrm{a}$ & 0.48 & $\mathrm{n} / \mathrm{a}$ \\
\hline $\mathrm{BeO}$ & 3.01 & $\mathrm{n} / \mathrm{a}$ & $\mathrm{n} / \mathrm{a}$ & 1.11 & 0.31 \\
\hline
\end{tabular}




\section{Specimen holder composition and drawing numbers}

Specimen holders for the metallic specimens shall be unalloyed powder metallurgy molybdenum per ASTM B387, Type 361 or Type 365.

Biaxial Creep Holders

Tensile Holders

Fracture Toughness Holders

Metallic Disk Holders

Compact Tension Holder
SK-AMT-2225

SK-AMT-2226

SK-AMT-2227

SK-AMT-2228

SK-AMT-2235

Sample holders for the ceramic specimens shall be POCO graphite AXF-5Q1.

Graphite Holders

BeO Compression Holder
SK-AMT-2240

SK-AMT-2241

\section{Capsule and internal hardware composition and drawing numbers}

Capsule

Head

Spacers

Insulators

Wave Spring

Shield

Flux Wire Assemblies

Passive Temperature Monitors
Stainless Steel Type 316H (ASME SA 479)

Stainless Steel Type 316H (ASME SA 479)

Molybdenum Type 361 or 365 (ASTM B387)

Stainless Steel Type 316 (ASTM A276)

Cr-Ni-Mo wire

Molybdenum Type 365 (ASTM B387)

Mo tubes and end plugs, Ni, Ti, Fe wire

$\mathrm{SiC}$ and $\mathrm{ZrC}$
SK-AMT-2221

SK-AMT-2222

SK-AMT-2223

SK-AMT-2224

SK-AMT-2239

SK-AMT-2220

SK-RRM-1011

5D14442 
Table A.5. Specimen holder, capsule internal hardware, and capsule weight by capsule type

\begin{tabular}{|c|c|c|c|}
\hline $\begin{array}{l}\text { Capsule } \\
\text { Assembly }\end{array}$ & $\begin{array}{c}\text { Capsule Hardware Used for Following } \\
\text { Specimen Types }\end{array}$ & $\begin{array}{c}\text { Designated } \\
\text { Assembly } \\
\text { Name }\end{array}$ & $\begin{array}{c}\text { Hardware } \\
\text { Weight (g) } \\
(10 \% \\
\text { contingency) }\end{array}$ \\
\hline 1 & $\begin{array}{c}\text { Metallic } \\
\text { Disk, Tensile, Biaxial Creep }\end{array}$ & DBU & 430 \\
\hline 2 & $\begin{array}{c}\text { Metallic } \\
\text { Disk, Tensile, Biaxial Creep }\end{array}$ & DBD & 430 \\
\hline 3 & $\begin{array}{c}\text { Metallic: } \\
\text { Disk, Biaxial Creep }\end{array}$ & $\mathrm{BCD}$ & 442 \\
\hline 4 & $\begin{array}{c}\text { Metallic } \\
\text { Disk, Tensile, Fracture Toughness, } \\
\text { Biaxial Creep, Compact Tensile }\end{array}$ & $\mathrm{A} 5 \mathrm{U}$ & 413 \\
\hline 5 & $\begin{array}{c}\text { Metallic } \\
\text { Disk, Tensile, Fracture Toughness, } \\
\text { Biaxial Creep, Compact Tensile }\end{array}$ & A5D & 413 \\
\hline 6 & $\begin{array}{c}\text { Metallic } \\
\text { Disk, Tensile, Fracture Toughness, }\end{array}$ & TFT & 429 \\
\hline 7 & $\begin{array}{c}\text { Ceramic } \\
\text { Disk, Tensile }\end{array}$ & SCA & 273 \\
\hline 8 & $\begin{array}{c}\text { Ceramic } \\
\text { BeO Disks, BeO Compression } \\
\text { Metal } \\
\text { Disks, Biaxial Creep, Compact Tensile }\end{array}$ & NBU & 387 \\
\hline 9 & $\begin{array}{c}\text { Ceramic } \\
\text { BeO Disks, BeO Compression } \\
\text { Metal } \\
\text { Disks, Biaxial Creep, Compact Tensile }\end{array}$ & NBD & 387 \\
\hline 10 & $\begin{array}{c}\text { Ceramic } \\
\text { Disk, Thin Strip Ceramic }\end{array}$ & BSR & 282 \\
\hline
\end{tabular}


Table A.6. Rig A mass estimate by capsule

\begin{tabular}{|c|c|c|c|c|c|c|}
\hline \multicolumn{7}{|c|}{$\begin{array}{c}\text { Rig 6A4 (“Rig A”) } \\
\text { Capsule Hardware \& Specimen } \\
\text { Weight (g) }\end{array}$} \\
\hline \multicolumn{7}{|c|}{ Capsule Type / Weight (g) (10\% margin included) } \\
\hline \multirow{2}{*}{\begin{tabular}{|c} 
Capsule \\
Elevation
\end{tabular}} & \multicolumn{6}{|c|}{ Compartment } \\
\hline & F1 & $\mathrm{F} 2$ & F3 & F4 & F5 & F6 \\
\hline Tier 5 & A5D / 470 & NBD / 439 & A5D / 473 & A5D / 521 & $\mathrm{DBU} / 457$ & $\mathrm{DBU} / 469$ \\
\hline Tier 4 & SCA / 299 & $\mathrm{~A} 5 \mathrm{U} / 521$ & $\mathrm{BCD} / 473$ & $\mathrm{BCD} / 467$ & $\mathrm{DBU} / 470$ & $\mathrm{BCD} / 479$ \\
\hline Tier 3 & SCA / 299 & A5U / 521 & $\mathrm{BCD} / 473$ & BCD / 467 & $\mathrm{DBU} / 470$ & BCD / 480 \\
\hline Tier 2 & TFT / 482 & A5U / 522 & $\mathrm{BCD} / 473$ & $\mathrm{DBU} / 457$ & $\mathrm{BCD} / 469$ & DBU / 469 \\
\hline Tier 1 & A5U / 472 & NBU / 439 & A5U / 521 & SCA / 298 & DBD / 458 & DBD / 469 \\
\hline
\end{tabular}

Table A.7. Rig B mass estimate by capsule

\begin{tabular}{|c|c|c|c|c|c|c|}
\hline \multicolumn{7}{|c|}{$\begin{array}{c}\text { Rig 6D4 (“Rig B”) } \\
\text { Capsule Hardware \& Specimen } \\
\text { Weight (g) }\end{array}$} \\
\hline \multicolumn{7}{|c|}{ Capsule Type / Weight (g) (10\% margin included) } \\
\hline \multirow{2}{*}{$\begin{array}{l}\text { Capsule } \\
\text { Elevation }\end{array}$} & \multicolumn{6}{|c|}{ Compartment } \\
\hline & F1 & F2 & F3 & F4 & F5 & F6 \\
\hline Tier 5 & TFT / 482 & NBD / 438 & A5D / 471 & BCD / 461 & BCD / 461 & A5D / 472 \\
\hline Tier 4 & BSR / 305 & TFT / 482 & $\mathrm{BCD} / 461$ & $\mathrm{~A} 5 \mathrm{U} / 521$ & $\mathrm{DBU} / 457$ & $\mathrm{DBU} / 469$ \\
\hline Tier 3 & TFT / 482 & DBD / 465 & A5D / 521 & $\mathrm{BCD} / 467$ & DBD / 459 & DBD / 469 \\
\hline Tier 2 & A5D / 472 & A5D / 522 & BCD / 474 & BSR / 305 & DBD / 457 & DBD / 470 \\
\hline Tier 1 & TFT / 482 & NBU / 438 & A5U / 471 & $\mathrm{BCD} / 461$ & BCD / 461 & A5U / 472 \\
\hline
\end{tabular}

\section{Best Estimate Capsule Hardware and Specimen Weight for Each Rig*}

Rig 6A4 $(\operatorname{Rig} A)=13,770 \mathrm{~g}$

Rig 6D4 $(\operatorname{Rig} B)=13,820 \mathrm{~g}$

*(10\% margin included $)$ 


\section{Attachment B}

SMIR and Core Loading Plans

The capsule layout in both Rigs A (6A4) and B (6D4) are schematically shown in Figure B1. There are 30 capsules for each rig for a total of 60 capsules. The capsules are arranged vertically to indicate tier (elevation) and horizontally to indicate compartment (radial positioning within the tier). The insert shown here represents PNNL's understanding of JAEA's compartment nomenclature. The filled triangle near the lower left (compartment \#1) represents the SMIR hex key which properly orients the SMIR in the JOYO core. The loading plan is based on this understanding.

For each compartment will include five (5) capsule tiers. Three capsule tiers will be within the core elevations while the two other capsule tiers will be below and above the core. Compartment "\#1" will contain the capsules that are closest to the JOYO core to achieve the highest fluence

Compartment \# (JNC Nomenclature)

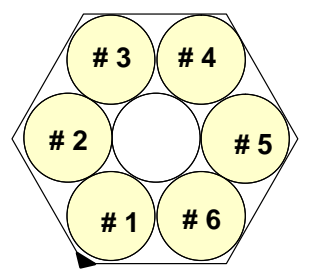

Hex Key Location within the rig. Similarly, compartment "\#4" will contain the capsules furthest from the core to achieve the lowest fluence within the rig. For the chosen rig positions there will be four zones of similar flux levels within each rig/tier combination. Hence compartment "\#6" and "\#2" will be very similar in flux/fluence as will compartments \#5 and \#3.

The bottom of each capsule will be marked with the Rig Identification, the compartment number and the tier, the capsule serial number, and capsule type. For example, the designation

\section{A4}

C2-T3

501

$\mathrm{BCD}$

would represent a capsule loaded into Rig A, Compartment \#2, Tier 3 (i.e., core centerline), capsule serial number 501; and capsule type BCD. 


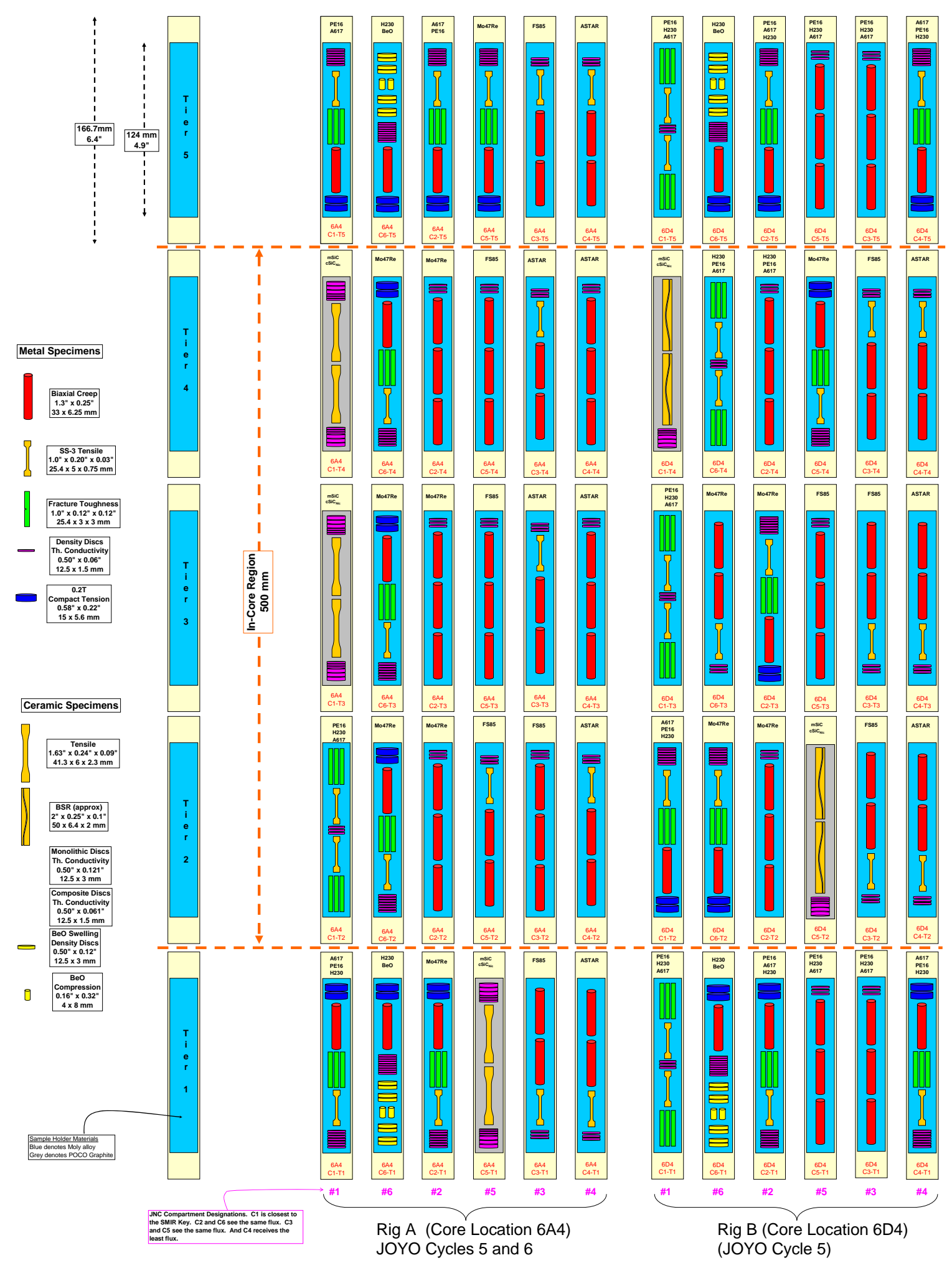

Figure B1. Capsule Loading Plan 


\section{Attachment C}

\section{$\underline{\text { Specimen Substitution }}$}

Specimen and Capsule Substitution Plan

Due to the large number of specimen type and material combinations coupled with the aggressive schedule demands for the JOYO-1 test matrix, anticipation of fabrication difficulties necessitates a "substitution strategy" to maintain sample numbers within each capsule. For example, if a specific specimen type of a certain material is not available during the capsule assembly process, another similar material of the same specimen type will be substituted in the capsule. This way the total number of specimens will be the same, as will be the total specimen volume within the capsule. When substitution is required, it is important that materials of similar density and composition be used as substitutes where possible. Such a substitution strategy preserves the integrity of the thermal and structural capsule design safety analyses. The list of substitute materials for each material in the JOYO-1 test matrix is listed in Table C-1. The only material listed as a substitute material that is not currently in the test matrix is Ta-10W which is a substitute for ASTAR-811C tensile and disc specimens. Ta-10W is very similar in composition and density to ASTAR-811C with the major differences being that the Hf and Re additions in ASTAR-811C are replaced with an equivalent weight of $\mathrm{W}$ and the lack of carbides in Ta-10W.

Table C-1, Specimen Material Substitution Material Specimen Types Substitute Material

\begin{tabular}{|c|c|c|}
\hline Material & Specimen Types & Substitute Material \\
\hline FS-85 & Biaxial Creep, Tensile, \& Disc & ASTAR-811C \\
\hline \multirow[t]{2}{*}{ ASTAR-811C } & Biaxial Creep & FS-85 or Mo-47Re \\
\hline & Tensile, \& Disc & Ta-10W, FS-85 \\
\hline Mo-47Re & $\begin{array}{c}\text { Biaxial Creep, Tensile, Disc, } \\
\text { Fracture Toughness, \& Compact } \\
\text { Tension }\end{array}$ & Mo-41Re \\
\hline $\operatorname{Re}$ & $\begin{array}{c}\text { Tensile, Disc, Fracture } \\
\text { Toughness }\end{array}$ & $\mathrm{W}$ or $\mathrm{W}-25 \mathrm{Re}$ \\
\hline $\mathrm{W}$ & $\begin{array}{c}\text { Tensile, Disc, Fracture } \\
\text { Toughness }\end{array}$ & W Re or W-25Re \\
\hline $\mathrm{W}-25 \mathrm{Re}$ & $\begin{array}{c}\text { Tensile, Disc, Fracture } \\
\text { Toughness }\end{array}$ & Re or W \\
\hline Alloy 617 & $\begin{array}{c}\text { Biaxial Creep, Tensile, Disc, } \\
\text { Fracture Toughness, \& Compact } \\
\text { Tension }\end{array}$ & Haynes 230 or Nimonic PE16 \\
\hline Haynes 230 & $\begin{array}{c}\text { Biaxial Creep, Tensile, Disc, } \\
\text { Fracture Toughness, \& Compact } \\
\text { Tension }\end{array}$ & Alloy 617 or Nimonic PE16 \\
\hline Nimonic PE16 & $\begin{array}{c}\text { Biaxial Creep, Tensile, Disc, } \\
\text { Fracture Toughness, \& Compact } \\
\text { Tension }\end{array}$ & Haynes 230 or Alloy 617 \\
\hline $\mathrm{SiC}$ & $\mathrm{n} / \mathrm{a}$ & None \\
\hline $\mathrm{SiCf} / \mathrm{SiC}$ & $\mathrm{n} / \mathrm{a}$ & None \\
\hline $\mathrm{BeO}$ & $\mathrm{n} / \mathrm{a}$ & None \\
\hline All & All & Stainless \\
\hline
\end{tabular}




\section{Capsule Substitution}

In the event that a capsule is 1) lost, 2) damaged, or 3) a disputed specimen content or inspection acceptance during receiving (as agreed by both PNNL and JNC), a substitute capsule shall take its place. The substitute capsule consists of a solid stainless steel capsule identical in size and configuration to the irradiation capsules. NRPCT will supply ten substitute (solid steel) capsules. 



\section{Appendix F}

\section{Draft Specific Memorandum Agreement}





\title{
Appendix F. Draft Specific Memorandum Agreement
}

\author{
SPECIFIC MEMORANDUM OF AGREEMENT \\ BETWEEN \\ THE UNITED STATES DEPARTMENT OF ENERGY \\ AND \\ THE JAPAN NUCLEAR CYCLE DEVELOPMENT INSTITUTE \\ ON COOPERATION IN THE FIELD OF \\ NUCLEAR REACTOR FUELS AND MATERIALS IRRADIATION TESTING
}

The Department of Energy (DOE) and the Japan Nuclear Cycle Development Institute (JNC) (hereinafter jointly referred to as the "Parties" or individually referred to as the "Party");

Noting that the both the United States and Japan signed the Agreement for Cooperation concerning Peaceful Uses of Nuclear Energy of November 4, 1987; and

Noting that both the United States and Japan have ratified the Treaty on Principles Governing the Activities of States in the Exploration and Use of Outer Space, including the Moon and other Celestial Bodies of January 27,1967; and

Noting that both DOE and JNC have agreed to institute long-term cooperation in the field of nuclear technologies under the Agreement between the Department of Energy of the United States of America and the Japan Nuclear Cycle Development Institute in the Field of Nuclear Technologies of August 22, 2000 (hereinafter referred to as the "Nuclear Technologies Agreement"); and

Desiring to cooperate in the field of nuclear reactor fuels and materials irradiation testing (under a Specific Memorandum of Agreement) in accordance with Articles 2 and 3 of the Nuclear Technologies Agreement;

Have agreed as follows:

\section{ARTICLE 1 \\ OBJECTIVE}

A. The objective of this Specific Memorandum is to establish a framework for cooperation between DOE, through its Office of Naval Reactors (NR), and JNC for utilization of JNC facilities and subcontractors to conduct nuclear reactor fuels and materials testing for NR's responsibility to deliver space reactors for the U.S. National Aeronautics and Space Administration.

B. Cooperation under this Specific Memorandum shall be carried out subject to the Nuclear Technologies Agreement.

C. Any fuels, materials, information and data transferred or acquired pursuant to this Specific Memorandum and contracts established pursuant to the Article 3 of this Specific Memorandum shall be used only for peaceful purposes. 


\section{ARTICLE 2}

\section{SCOPE OF AGREEMENT}

Cooperation under this Specific Memorandum will be the subject of detailed agreements or contracts between JNC and organizations authorized to act on behalf of DOE pursuant to Article 3 of this Specific Memorandum (hereinafter referred to as the "DOE Contractors"). Cooperation under this Specific Memorandum includes but shall not be limited to the following:

A. All aspects related to the irradiation testing of fuels and materials including design and/or review of irradiation test set-ups, fuels and materials fabrication and preparation, irradiation testing, and, post irradiation examination (PIE), shipping, and associated disposition activities.

(1) Non-fuel bearing materials which are brought to JNC by DOE are property of DOE and DOE shall assume responsibility for their final disposition unless otherwise agreed to by the Parties or otherwise specified in a contract pursuant to Article 3 of this Specific Memorandum.

(2) Fuel bearing materials which are brought to JNC by DOE shall be returned to DOE facilities and DOE shall assume responsibility for their final disposition unless otherwise agreed to by the Parties.

B. Delivery of test information and test data.

C. Other activities necessary to achieve the objective of this Specific Memorandum as detailed in contracts between JNC and DOE Contractors or as agreed to by the Parties.

\section{ARTICLE 3}

\section{MANAGEMENT}

DOE contractors may establish contracts with JNC to accomplish the objective of this Specific Memorandum.

\section{ARTICLE 4}

FINANCE

Financial arrangements to accomplish the objective of this Specific Memorandum will be specified in contracts between JNC and DOE Contractors unless otherwise agreed to by the Parties.

\section{ARTICLE 5}

\section{ASSIGNMENT OF STAFF}

DOE may wish to periodically send representatives from DOE Contractors to JNC to facilitate communications and foster more effective working relationships between the Parties. Dates of the visits of the representatives shall be agreed between DOE and JNC.

\section{ARTICLE 6 \\ INFORMATION USE AND DISCLOSURE}

Information use and disclosure under this Specific Memorandum shall be in accordance with Article 6 and 7.3 of the Nuclear Technologies Agreement and contracts between JNC and the DOE Contractors. Results of the irradiation testing and post irradiation examinations shall be 
treated as "business confidential" unless otherwise agreed by DOE. Use of "business confidential" information by JNC will be determined on a case-by-case basis.

Conditions imposed by DOE on JNC's use of "business confidential" information shall continue to apply without respect to time and notwithstanding the expiration or termination of this Specific Memorandum, unless otherwise agreed by DOE in writing.

\section{ARTICLE 7 \\ INTELLECTUAL PROPERTY RIGHTS}

The protection and allocation of intellectual property created as a result of cooperation under this Specific Memorandum shall be governed by Article 7 of the Nuclear Technologies Agreement and contracts between JNC and DOE Contractors.

\section{ARTICLE 8 GENERAL PROVISIONS}

A. Any questions or disputes of interpretation or implementation relating to this Specific Memorandum arising during its term shall be resolved in accordance with the contracts between JNC and the DOE Contractors or by agreement of the Parties in accordance with Article 10 of the Nuclear Technologies Agreement.

B. In the event of any inconsistency between the provisions of this Specific Memorandum and a contract concluded pursuant to Article 3 of this Specific Memorandum, the provisions of the former shall prevail.

\section{ARTICLE 9}

\section{DURATION, AMENDMENT, AND TERMINATION}

A. This Specific Memorandum shall enter into force upon signature by both parties and (subject to paragraph $\mathrm{C}$ of this Article), shall remain in force for the duration of the irradiation testing and post irradiation examinations of fuels and materials.

B. The activities under the contracts established pursuant to the Article 3 of this Specific Memorandum not completed at the termination or expiration of this Specific Memorandum may, if agreed by the Parties, be continued until their completion under the terms of this Specific Memorandum.

C. This Specific Memorandum may be amended by written agreement of the Parties.

D. This Specific Memorandum may be terminated at any time by both Parties, and at the discretion of either Party upon ninety (90) days advance notification in writing by the Party seeking to terminate this Specific Memorandum. 
IN WITNESS WHEREOF, the undersigned, duly authorized, have signed this Specific Memorandum.

FOR THE DEPARTMENT OF ENERGY OF THE UNITED

STATES OF AMERICA:
FOR THE JAPAN NUCLEAR CYCLE DEVELOPMENT INSTITUTE:
Date:

Place:
Date:

Place: 


\section{Appendix G}

\section{Draft Statement of Work of Long Lead Items to Support Future}

Irradiation Efforts 



\title{
Appendix G. Draft Statement of Work of Long Lead Items to Support Future Irradiation Efforts
}

\author{
STATEMENT OF WORK \\ Procurement of Long Lead Raw Materials to Support the \\ Irradiation of Structural Materials in JOYO Cycles 7 and 8 \\ JOYO Irradiation Testing Project (Phase 2)
}

June 3, 2005

\subsection{OBJECTIVE}

To provide work scope and funding to allow the Japan Nuclear Cycle Development Institute (JNC) to procure long lead materials so that a sufficient number of parts can be fabricated (at some later time under a separate agreement) for 2 Structural Materials Irradiation Rigs (SMIRs). For planning purposes the long lead materials need to be procured on a schedule that is consistent with having materials on hand to build parts in time to support a $2^{\text {nd }}$ irradiation campaign in cycles 7 and 8 of the JOYO Experimental Fast Reactor.

\subsection{BACKGROUND}

The procurement of long lead items by JNC for two additional SMIRs will be funded by Pacific Northwest National Laboratory (PNNL) operated by the Battelle Memorial Institute's, Pacific Northwest Division for the United States Department of Energy. PNNL's customer for this effort, the Naval Reactors Prime Contractor Team (NRPCT), has directed that advanced planning be developed by PNNL such that a second irradiation of 2 SMIRs would be possible in JOYO cycle 7 and 8. As a first step to ensure that a second campaign can occur, PNNL is providing work scope and funding to JNC to procure long lead raw materials.

The desired schedule is as follows:

$\mathrm{JNC}$ procure long lead items to support future irradiation July 2005 - Aug 2006

JNC converts raw materials into parts for 2 additional SMIRs (not currently funded) Sep 2006 - July 2007

JNC assembles 2 additional SMIRs (not currently funded) Aug 2007 - Nov 2007

JOYO cycle 7 start date Dec 2007 
These long lead items are being procured separate from the assembly and irradiation services contract to ensure that materials are available to allow future options for the program to exercise.

\subsection{WORK SCOPE}

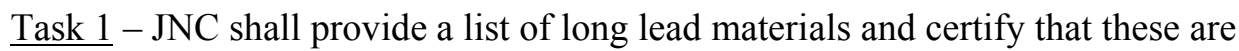
sufficient to ensure materials are available to build parts for 2 additional SMIRs.

$\underline{\text { Task } 2}-\mathrm{JNC}$ shall establish contracts to procure all necessary long lead materials.

$\underline{\text { Task } 3}$ - JNC shall receive all long lead materials and provide safe and proper storage of these materials until at least December 2007.

\subsection{DELIVERABLES AND SCHEDULE}

Due dates associated with this work scope are as follows:

Deliverable 1: $\quad$ Prepare list of long lead materials and certify that the list of materials are sufficient to build parts for 2 additional SMIRs.

\section{Due Date: $\quad$ Thirty days after contract award.}

Deliverable 2: $\quad$ Receipt of all parts necessary to assemble 2 SMIRs.

\section{Due Date: $\quad$ Not later than August 2006}

\subsection{QUALITY ASSURANCE REQUIREMENTS}

JNC shall provide written certification that the list of materials procured will be sufficient to ensure that parts for 2 future SMIRs can be fabricated at a later date. The certification shall contain the following information and shall be submitted to PNNL on JNC letterhead.
A. JNC's name and address
B. Purchase order number
C. Name and signature of certifying authority

\subsection{HOLD AND VERIFICATION POINTS}

None.

\subsection{INTERFACES}

JNC staff shall interface with the following PNNL personnel or their delegates: 
Contracts

Technical

Quality Assurance

8.0
Doug Akers (509-372-6722)

Chad Painter (509-372-4112) or David Senor (509-376-5610)

Thomas Hays (509-376-2429)

\section{REPORTING}

A monthly emailed progress report shall be issued by JNC to PNNL. These reports shall be due to PNNL before the $5^{\text {th }}$ of each month. 



\section{Appendix H}

TN6-4 Cask Specifications 



\section{Appendix H. TN6-4 Cask Specifications}

Packaging model

Package type

Competent authority identification markers

Transport index

Criticality safety index

Package weight

Outer dimensions of packaging

Packaging weight

Outer shell, inner shell, intermediate shell, lids/covers materials

Shielding materials

Shock-absorption materials

Inner container, fuel supporting cans, supporting cans, racks, receiving tubes materials Stainless steel Type 304

Transportation method

Cooling system
TN6-4

Type $\mathrm{B}(\mathrm{U})$ package for fissile material Top-loading

J/85/B(U)F-96

7.7

0

$\operatorname{Max} 11,000 \mathrm{~kg}$

Length approximately $3.27 \mathrm{~m}$ Width approximately $1.4 \mathrm{~m}$ Height approximately $1.4 \mathrm{~m}$

Max 10,860 kg

Stainless steel Type 304

Lead, resin

Balsa wood
Truck, ship (no rail)

Natural-air cooling 



\section{Distribution}

No. of

Copies

OFFSITE

5 KAPL, Inc.

Attn: Steve Hayden (M/S 111)

P.O. Box 1072

Schenectady, NY 12301

ONSITE

$8 \quad$ Pacific Northwest National Laboratory
C. L. Painter (3)
K8-60
D. J. Senor (3)
P8-10
Information Release Office (2) P8-55

Dist.1 
Enclosure 3 to

MDO-723-0057

PAGE 1

\section{Enclosure 3}

Application of Nuclear Hazard Indemnity Clause to the Irradiation of Space Reactor Materials in the JOYO Experiment Fast Reactor Project

White Paper

Chad Painter, Project Manager

(Revised March 15, 2005) 
Enclosure 3 to

MDO-723-0057

PAGE 2

\title{
Application of Nuclear Hazard Indemnity Clause to the Irradiation of Space Reactor Materials in the JOYO Experiment Fast Reactor Project
}

\author{
White Paper \\ Chad Painter, Project Manager \\ (Revised March 15, 2005)
}

\section{Background:}

PNNL was recently tasked by the Naval Reactors Prime Contract Team (NRPCT) to support a civilian space reactor development effort by providing technical expertise in the area of materials irradiation, post irradiation examination, and fast reactor expertise. PNNL's first task is to establish a subcontract with the Japan Nuclear Cycle Development Institute (JNC) to ensure that long lead items are available to support the irradiation of structural materials in the JOYO Experimental Fast Reactor. In advance of this first subcontract Naval Reactors has requested a position paper from PNNL on the applicability of the Price-Anderson Amendments Act (PAAA) to the JOYO irradiation work.

In 1988, Congress passed the PAAA, which re-authorized and altered the system of financial protection for U.S. Department of Energy (DOE) contractors who may be liable for damages resulting from nuclear incidents that occur at the facilities they operate. Specifically, the PAAA requires DOE to include a Nuclear Hazard Indemnity Clause in its management and operating contracts to indemnify contractors for such damages. In exchange for this indemnification, the PAAA requires that DOE contractors comply with a rigorous set of nuclear safety rules and that DOE institute processes that confirm DOE contractor compliance.

The PAAA authorizes DOE to issue Notices of Violation against any contractors who are indemnified under the PAAA for violations of DOE nuclear safety regulations, implementation plans, or compliance orders. The Secretary of Energy is authorized to impose civil penalties of as much as $\$ 110,000$ per violation or $\$ 110,000$ per violation per day for continuing violations. However, the PAAA statute and 10 CFR Part 820.20(c)(7), provides that "Battelle Memorial Institute for activities associated with Pacific Northwest Laboratory (sic)" is exempted from civil penalties. While PNWD (and its suppliers and vendors) is currently exempt from civil penalties under the Act, the Laboratory can incur significant costs in responding to enforcement actions.

The Act also subjects personnel employed by indemnified contractors to possible criminal liability for knowing and willful violations of nuclear safety rules. DOE refers such cases to the US Department of Justice for criminal prosecution, while retaining the right to pursue regulatory enforcement actions for violations arising out of the same event. The goal of DOE's enforcement policy is to ensure compliance with nuclear safety rules by encouraging timely identification, open and prompt reporting, and comprehensive correction of noncompliant conditions. The cornerstone of DOE's enforcement policy is voluntary compliance through contractor initiatives identified to effectively understand and implement nuclear safety requirements; critically self-assess activities; and promptly identifies, report, and correct noncompliant conditions. 
At PNNL, PAAA applies to all DOE work to which the Nuclear Hazard Indemnity clause applies and that has the "potential to cause radiological harm." Generally, PAAA is applicable to

- Management systems that establish processes for meeting the requirements of $10 \mathrm{CFR}$ 708, 10 CFR 820.11, 10 CFR 830 Subparts A and B, and 10 CFR 835,

- Work that has the potential for radiological harm and to which the DOE Nuclear Hazard Indemnity clause applies. This includes:

o work scope authorized through the 1830 Contract (e.g., DOE Direct Funded Work, Related Services, Other Hanford Contractors, Work for Others, Work for Other DOE Sites). This includes the JOYO project as a whole.

o work scope funded by DOE and authorized through the 1831 Use Permit.

Work that has the "potential to cause radiological harm" is defined (in the Price-Anderson Amendments Act subject area) as any activity (including providing items or services)

- that has the potential to affect facilities, activities, or operations that involve or will involve any amount of radioactive and/or fissionable materials, or

- that involves the use, storage, transportation, or disposal of radioactive material, the use of radiation-generating devices, or potential exposure to ionizing radiation.

PAAA Application to JOYO Irradiation:

Battelle Memorial Institute is indemnified against civil liability arising from nuclear incidents by the Department of Energy through its contract with DOE to operate PNNL. The DOE indemnifies Battelle, and its subcontractors and vendors, against civil claims for public liability which arise out of or in connection with activities performed under its DOE contract (i.e., JOYO irradiation project) and result from a nuclear incident as defined in PAAA.

For a nuclear incident resulting from a DOE contractual activity within the United States, public liability is limited by a formula that results in a current limit of approximately $\$ 10$ billion. Liability protection for nuclear incidents outside of the United States is limited to $\$ 100$ million.

The term "nuclear incident" as defined in the Atomic Energy Act of 1954, means "any occurrence, including an extraordinary nuclear occurrence, within the United States causing, within or outside the United States, bodily injury, sickness, disease, or death, or loss of or damage to property, or loss of use of property, arising out of or resulting from the radioactive, toxic, explosive, or other hazardous properties of source, special nuclear ${ }^{4}$, or (byproduct material $)^{5}$ : Provided, however, That as the term ....... is used in section $170 \mathrm{~d}$, it shall include any such occurrence outside the United States if such occurrence involves source, special nuclear, or byproduct material owned by, and used by or under contract with, the United

\footnotetext{
${ }^{4}$ Special Nuclear Material - means (1) plutonium, uranium enriched in the isotope 233 or in the isotope 235, and any other material which the Commission, pursuant to the provisions of section 51, determines to be special nuclear material, but does not include source material; or (2) any material artificially enriched by any of the foregoing, but does not include source material.

${ }^{5}$ Byproduct Material - "any radioactive material (except special nuclear material) yielded in or made radioactive by exposure to the radiation incident to the process of producing or utilizing special nuclear material ....”
} 
States..." Section $170 \mathrm{~d}$ specifies the indemnification of Contractors by the Department of Energy.

Because the definition of nuclear incident includes occurrences outside the United States that involve byproduct material owned by, and used by or under contract with the United States, PAAA does apply to the JOYO irradiation project work and a nuclear hazards indemnity clause like the one shown in Attachment 1 should be included in the JNC contract.

\section{PNNL Position:}

PNNL proposes the following approach: First, that language be included in the DOE/JNC separate agreement to address the risk of liability that might occur as a result a nuclear incident potentially caused by, or associated with, the irradiation of structural materials in the JOYO Experimental Fast Reactor. Proposed language is included below and would essentially require each party to seek compensation in the event of a nuclear incident through their existing legal framework (i.e., JNC is indemnified by their government in a similar manner that PNNL is indemnified by DOE). This would be the easiest approach in terms of contract negotiations and eliminate the necessity to pass down additional requirements.

\section{ARTICLE XX - DAMAGES}

Each Party acknowledges and agrees that it relies upon its own national law to provide compensation for damages to itself arising out of or resulting from activities under this Agreement and it will not look to the other Party for such compensation.

If this approach were not acceptable to either JNC or DOE, then the Nuclear Hazards Indemnity clause would be passed down in the JNC irradiation services contract. Along with the indemnity clause, PNNL would also need to pass down the applicable DOE nuclear safety requirements which would need to be satisfied, as applicable, by JNC in addition to their own quality and safety requirements. 
Attachment 1 to

Enclosure 3 of

MDO-723-0057

PAGE 1

Attachment 1 to Enclosure 3

Nuclear Hazard Indemnity Clause

PNNL Recommended Addendum to comply with Price -Anderson Amendments Act

NRC Interpretation of Price-Anderson Amendments Act of 1999

PRE-DECISIONAL - For Planning and Discussion Purposes Only 


\section{Attachment 1}

\section{NUCLEAR HAZARDS INDEMNITY AGREEMENT (JUN 1996)}

A. Authority. This clause is incorporated into this Contract pursuant to the authority contained in subsection 170d of the Atomic Energy Act of 1954, as amended (hereinafter called the Act).

B. Definitions. The definitions set out in the Act shall apply to this clause.

C. Financial Protection. Except as hereafter permitted or required in writing by DOE, the Contractor will not be required to provide or maintain, and will not provide or maintain at Government expense, any form of financial protection to cover public liability, as described in paragraph D.2 below. DOE may, however, at any time require in writing that the Contractor provide and maintain financial protection of such a type and in such amount as DOE shall determine to be appropriate to cover such public liability, provided that the costs of such financial protection are reimbursed to the Contractor by DOE.

\section{Indemnification.}

1. To the extent that the Contractor and other persons indemnified are not compensated by any financial protection permitted or required by DOE, DOE will indemnify the Contractor and other persons indemnified against (i) claims for public liability as descried in subparagraph D.2 of this clause; and (ii) such legal costs of the Contractor and other persons indemnified as are approved by DOE, provided that DOE's liability, including such legal costs, shall not exceed the amount set forth in section 170e.(1)(B) of the Act in the aggregate for each nuclear incident or precautionary evaluation occurring within the United States or \$100 million in the aggregate for each nuclear incident occurring outside the United States, irrespective of the number of persons indemnified in connection with this contract.

2. The public liability referred to in subparagraph D.1 of this Clause is public liability as defined in the Act which (i) arises out of or in connection with the activities under this Contract, including transportation; and (ii) arises out of or results from a nuclear incident or precautionary evacuation, as those terms are defined in the Act.

\section{E. Waiver of Defenses.}

1. In the event of a nuclear incident, as defined in the Act, arising out of nuclear waste activities, as defined in the Act, the Contractor, on behalf of itself and other persons indemnified, agrees to waive any issue or defense as to charitable or governmental immunity.

2. In the event of an extraordinary nuclear occurrence which:

I. Arises out of, results from, or occurs in the course of the construction, possession, or operation of a production or utilization facility; or

II. Arises out of, results from, or occurs in the course of transportation of source material, by-product material, or special nuclear material to or from a production or utilization facility; or

III. Arises out of or results from the possession, operation, or use by the Contractor or a subcontractor of a device utilizing special nuclear material or by-product material, during the course of the contract activity; or

IV. Arises out of, results from, or occurs in the course of nuclear waste activities, the Contractor, on behalf of itself and other persons indemnified, agrees to waive: 
A. Any issue or defense as to the conduct of the claimant (including the conduct of persons through whom the claimant derives its cause of action) or fault of persons indemnified, including, but not limited to:

1. Negligence;

2. Contributory negligence;

3. Assumption of risk; or

4. Unforeseeable intervening causes, whether involving the conduct of a third person or an act of God;

B. Any issue or defense as to charitable or governmental immunity; and

C. Any issue or defense based on any statue of limitations, if suit is instituted within 3 years from the date on which the claimant first knew, or reasonably could have known, of his injury or change and the cause thereof. The waiver of any such issue or defense shall be effective regardless of whether such issue or defense may otherwise be deemed jurisdictional or relating to an element in the cause of action. The waiver shall be judicially enforceable in accordance with its terms by the claimant against the person indemnified.

$\mathrm{V}$. The term extraordinary nuclear occurrence means an event that DOE has determined to be an extraordinary nuclear occurrence as defined in the Act. A determination of whether or not there has been an extraordinary nuclear occurrence will be made in accordance with the procedures in 10 CFR Part 840.

VI. For the purposes of that determination, "offsite" as that term is used in 10 CFR Part 840 means away from "the contract location” which phrase means any DOE facility, installation, or site at which contractual activity under this contract is being carried on, and any Contractor-owned or controlled facility, installation, or site at which the Contractor is engaged in the performance of contractual activity under this contract.

3. The waivers set forth above:

I. Shall be effective regardless of whether such issue or defense may otherwise be deemed jurisdictional or relating to an element in the cause of action;

II. Shall be judicially enforceable in accordance with its terms by the claimant against the person indemnified;

III. Shall not preclude a defense based upon a failure to take reasonable steps to mitigate damages;

IV. Shall not apply to injury or damage to a claimant or to a claimant's property which is intentionally sustained by the claimant or which results from a nuclear incident intentionally and wrongfully caused by the claimant;

V. Shall not apply to injury to a claimant who is employed at the site of and in connection with the activity where the extraordinary nuclear occurrence takes place, if benefits therefore are either payable or required to be provided under any workmen's compensation or occupational disease law; 
VI. Shall be effective only with respect to those obligations set forth in this clause and in insurance policies, contracts or other proof of financial protection; and

VII. Shall not apply to, or prejudice the prosecution or defense of, any claim or portion of claim which is not within the protection afforded under (A) the limit of liability provisions under subsection 170e of the Act, and (B) the terms of this agreement and the terms of insurance policies, contracts, or other proof of financial protection.

F. Notification and Litigation of Claims. The Contractor shall give immediate written notice to DOE of any known action or claim filed or made against the Contractor or other person indemnified for public liability as defined in paragraph D.2. Except as otherwise directed by DOE, the Contractor shall furnish promptly to DOE, copies of all pertinent papers received by the Contractor or filed with respect to such actions or claims. DOE shall have the right to, and may collaborate with, the Contractor and any other person indemnified in the settlement or defense of any action or claim and shall have the right to (1) require the prior approval of DOE for the payment of any claim that DOE be required to indemnify hereunder; and (2) appear through the Attorney General on behalf of the Contractor or other person indemnified in any action brought upon any claim that DOE may be required to indemnify hereunder; take charge of such action, and settle or defend any such action. If the settlement or defense of any such action or claim is undertaken by DOE, the Contractor or other person indemnified shall furnish all reasonable assistance in effecting a settlement or asserting a defense.

G. Continuity of DOE Obligations. The obligations of DOE under this Clause shall not be affected by any failure on the part of the Contractor to fulfill its obligation under this Contract and shall be unaffected by the death, disability, or termination of existence of the Contractor, or by the completion, termination or expiration of this Contract.

H. Effect of Other Clauses. The provisions of this clause shall not be limited in any way by, and shall be interpreted without reference to any, other clause of this contract, including the clause entitled Contract Disputes provided, however, that this clause shall be subject to the clauses entitled Covenant Against Contingent Fees, Officials Not to Benefit, and Examination of Records by the Comptroller General, and any provisions that are later added to this Contract as required by applicable Federal law, including statues, executive orders and regulations, to be included in Nuclear Hazards Indemnity Agreements.

I. Reserved. (The Contractor is specifically exempt from civil penalties pursuant to Section 234 of the Price-Anderson Amendment Act of 1988.) 
J. Criminal Penalties. Any individual director, officer, or employee of the Contractor or of its subcontractors and suppliers who are indemnified under the provisions of this Clause are subject to criminal penalties, pursuant to 223(c) of the Act, for knowing and willful violation of the Atomic Energy Act of 1954, as amended, and applicable DOE nuclear safety-related rules, regulations or orders which violation results in, or, if undetected, would have resulted in a nuclear incident.

K. Inclusion in Subcontract. The Contractor shall insert this clause in any subcontract that may involve the risk of public liability, as that term is defined in the Act and further described in paragraph D.2 above. However, this clause shall not be included in subcontracts in which the subcontractor is subject to Nuclear Regulatory Commission (NRC) financial protection requirements under section 170b of the Act or NRC agreements of indemnification under section 170c or $\mathrm{k}$ of the Act for the activities under the subcontract.

L. This indemnity agreement shall be applicable with respect to nuclear incidents occurring on or after August 20, 1988. 


\section{PRICE-ANDERSON AMENDMENTS ACT (SEP 1999)}

In additional to standard Quality, ES\&H, and applicable contract clauses and requirements the following shall apply:

\section{Indemnification for Nuclear Safety Violations}

a. Applicability. The provisions of this clause shall be applicable if the Contractor's products or services are subject to the nuclear hazards indemnity provisions of section 170 of the Atomic Energy Act of 1954, as amended, and the U.S. Department of Energy's Nuclear Safety Requirements as described in Title 10, Code of Federal Regulations, Part 820 (10 CFR Part 820), or could otherwise have any effect on nuclear or radiological safety.

b. The Contractor assumes full responsibility and shall indemnify, save harmless, and defend Battelle, its directors, officers and employees from any civil liability under §234A of the Atomic Energy Act of 1954, as amended, or the implementing regulations, arising out of the activities of the Contractor, its subcontractors, suppliers, agents, employees, and their officers, or directors. The Contractor's obligation to indemnify and hold harmless shall expressly include attorney fees and other reasonable costs of defending any action or proceeding instituted under $\S 234 \mathrm{~A}$ or the implementing regulations.

2. Nuclear Safety Requirements

a. Applicability. The provisions of this clause apply to any activity carried out pursuant to this contract by the Contractor, its subcontractors, suppliers, and employees that has the potential to result in a risk of harm to an individual from radiation or radioactive material, or the potential to affect a nuclear facility or radiological activity. The term "individual" as used in this clause includes, without limitation, general employees, radiological workers, embryo/fetus of a declared pregnant worker, minors, and members of the public. The requirements of this clause do not apply to activities that are regulated through a license by the Nuclear Regulatory Commission or a State under an Agreement with the Nuclear Regulatory Commission (an Agreement State), including activities certified by the Nuclear Regulatory Commission under §1701 (42 USC §2297(f)) of the Atomic Energy Act of 1954, as amended. Other specific applicability exclusions are identified in 10 CFR $\S 820$ and related Department of Energy regulations.

b. The Contractor shall: (1) comply with all applicable requirements of Title 10, Code of Federal Regulations, Part 835, “Occupational Radiation Protection” (10 CFR Part 835). The Contractor's programs and associated documents are subject to review at all times by Battelle.

c. The Contractor shall: (1) comply with all applicable requirements of Title 10, Code of Federal Regulations, Part 830.120, “Quality Assurance Requirements” (10 CFR 830.120), or a quality assurance program that meets the stated requirements of Title 10, Code of Federal Regulations, Part 830.120, and (2) implement, document, and maintain such programs (e.g., administrative controls, procedures, and technical work documents) as necessary to 
ensure compliance with the QA requirements section of this contract. The Contractor's programs and associated documents are subject to review at all times by Battelle.

d. The Contractor shall: (1) comply with all applicable requirements of Title 10, Code of Federal Regulations, Part 708, “Contractor Employee Protection” (10 CFR 708), and (2) implement, document, and maintain such programs as necessary to ensure compliance with this requirement. The Contractor's programs and associated documents are subject to review at all times by Battelle.

e. The Contractor shall: (1) comply with all applicable requirements of newly promulgated Department of Energy nuclear safety requirements in Title 10, Code of Federal Regulations, and (2) implement, document, and maintain such programs as necessary to ensure compliance with these requirements. The Contractor's programs and associated documents are subject to review at all times by Battelle.

f. The Contractor shall include the provisions of this clause, including this paragraph, in all lower tier Contracts for any activity subject to the applicability requirements in paragraph a.

g. If any noncompliance or deficiency occurs in the programs or activities subject to this clause, or a lack of appropriate or timely corrective action by the Contractor, causes a potential violation of nuclear safety requirements, then the Contractor may be subject to enforcement penalties under the Atomic Energy Act, 10 CFR 820 and/or other provisions of this contract.

h. Where reporting of a potential violation of a nuclear safety requirement to the DOE is necessary, the Contractor shall report through Battelle. 


\section{§ 8.2 INTERPRETATION OF PRICE-ANDERSON ACT, SECTION 170 OF THE ATOMIC ENERGY ACT OF 1954.}

(a) It is my opinion that an indemnity agreement entered into by the Atomic Energy Commission under the authority of the Atomic Energy Act of 1954 (42 U.S.C. 2011, et seq.), hereafter cited as "the Act," as amended by Pub. L. 85-256 (the "Price-Anderson Act") 42 U.S.C. 2210 indemnifies persons indemnified against public liability for bodily injury, sickness, disease or death, or loss of or damage to property, or for loss of use of property caused outside the United States by a nuclear incident occurring within the United States.

(b) Section 170 authorizes the Commission to indemnify against "public liability" as defined in section 11(u) of the Act. ${ }^{1}$ Coverage under the Act therefore is predicated upon "public liability," and requires (1) "legal liability" for (2) a "nuclear incident." Determination of the Act's coverage, therefore, necessitates a finding that these two elements are present.

(c) In the case of damage outside of the United States caused by a nuclear facility based in the United States there would be a "nuclear incident" as defined in section 11(o) since there would be an "occurrence within the United States causing *** damage." United States" since "occurrence" is intended by the Act to be "that event at the site of the licensed activity *** which may cause damage rather than the site where the damage may perhaps be caused." (S. Rep. 296, 85th Cong., 1st Sess., p. 16 1957) (hereafter cited as Report). In section 11(o) an "occurrence" is that which causes damage. It would be, therefore, an event taking place at the site. This definition of "occurrence" is referred to in the Report at page 22 and is crucial to the Act's placing of venue under section $170(\mathrm{e})^{-3} 027$ In its definition of "nuclear incident." The Act makes no limitation upon the place where the damage is received but states only that the "occurrence" must be within the United States.

(d) Similarly, the requirement of "legal liability" would be met. The words of the Act impose no limitation that the liability be one for damage caused in the United States but, on the contrary, are exceedingly broad permitting indemnification for "any legal liability." In the most exhaustive study of the subject, it is stated that the phrase "any legal liability" indicates that liability for damage outside the United States is covered by the Act. Atomic Industrial Forum, Financial Protection Against Atomic Hazards 61 n. 355 (1957).

(e) Thus the precise language of the Act provides coverage for damage ensuing both within and without the United States arising out of an occurrence within the United States. There would be no occasion for doubt were it not for a single statement contained in the Report of the Joint Committee on Atomic Energy on the Price-Anderson Act. The Report states, at p. 16 that "[i]f there is anything from a nuclear incident at the licensed activity which causes injury abroad, or if there is any activity abroad which causes further injury in the United States the situation will require further investigation at that time." This sentence follows an explicit and lengthy statement that the "occurrence" is an event at the site of the activity:

${ }^{10}$ Report, p. 11. 
** The occurrence which is the subject of this definition is that event at the site of the licensed activity, or activity for which the Commission has entered into a contract, which may cause damage, rather than the site where the damage may perhaps be caused. This site must be within the United States. The suggested exclusion of facilities under license for export was not accepted. This is because the definition of "nuclear incident" limits the occurrence causing damage to one within the United States. It does not matter what license may be applicable if the occurrence is within the United States. If there is anything from a nuclear incident at the licensed activity which causes injury abroad or if there is any activity abroad which causes further injury in the United States the situation will require further investigation by the Congress at that time $* * *$

Read literally, the last sentence would seem inconsistent with the preceding statement. It is, however, possible to read the sentence as consistent with the preceding statement if it is taken as indicating a recognition by Congress of the fact that the statutory limitation of liability to $\$ 500,000,000$ would probably not limit claims by foreign residents to that amount in foreign courts and that therefore the persons indemnified were not fully protected against bankrupting claims, one of the primary purposes of the bill. ${ }^{4}$

(f) The point in question received scant consideration during the hearings preceding adoption of the bill held by the Joint Committee on Atomic Energy. A summary of the study of the Atomic Industrial Forum, cited above, was introduced into the record of the hearing and included a conclusion that the provisions of the bill seemed to cover the situation. ${ }^{-}$That conclusion would seem entitled to more than ordinary weight since the Forum study received the careful consideration of the Joint Committee. ${ }^{6}$ and the study referenced a statement from the 1956 Report very similar to the confusing statement in the 1957 Report noted above. ${ }^{7}$

(g) There was also a rather ambiguous colloquy in the hearings between Representative Cole and Mr. Charles Haugh in which Representative Cole indicated that the Joint Committee

$" * * *$ will do pretty well if we successfully protect the American people and property owners in this country without worrying about those that live abroad." $\underline{8}$

(h) Congress, in enacting the Price-Anderson Indemnity Act added to section 2 of the Atomic Energy Act of 1954, a new subsection which stated, inter alia:

In order $* * *$ to encourage the development of the atomic energy industry, *** the United States may make funds available for a portion of the damages suffered by the public from nuclear incidents and may limit the liability of those persons liable for such losses.

This statutory purpose is frustrated if the atomic energy industry is not protected from bankrupting liabilities for damages caused abroad by an accident occurring in the United States. ${ }^{\underline{9}}$ In the Report, the Joint Committee on Atomic Energy made explicit mention of the fact that the private insurance to be provided for reactor operators included coverage for damage in Canada and Mexico and, at another point, noted the Committee's hope that the insurance contract in its final form would cover the same scope as the bill.10 $\underline{\underline{10}}$ 
(i) It is my opinion that since the language of the Act draws no distinction between damage received in the United States and that received abroad, none can properly be drawn. To read the Act as imposing such a limitation in the absence of statutory direction and in the light of an avowed Congressional intention to encourage the development of the atomic energy industry would be unwarranted. The confusing sentence cited in the Report must, therefore, be read consistently with the language of the Act in the manner suggested above, i.e., as recognizing Congressional inability to limit foreign liability, or must be ignored as inconsistent with the broad coverage of the statutory language.

\section{[25 FR 4075, May 7, 1960]}

${ }^{1}$ Sec. $11 \mathrm{u}$ "The term 'public liability' means any legal liability arising out of or resulting from a nuclear incident, except claims under State or Federal Workmen's Compensation Acts of employees of persons indemnified who are employed at the site of and in connection with the activity where the nuclear incident occurs, and except for claims arising out of an act of war. 'Public Liability' also includes damage to property of persons indemnified: Provided, That such property is covered under the terms of the financial protection required, except property which is located at the site of and used in connection with the activity where the nuclear incident occurs."

${ }^{2}$ Sec. 11o. "The term 'nuclear incident' means any occurrence within the United States causing bodily injury, sickness, disease, or death, or loss of or damage to property, or for loss of use of property, arising out of or resulting from the radioactive, toxic, explosive, or other hazardous properties of source, special nuclear, or byproduct material: ***"

3 "In order to provide a framework for establishing the limitation of liability, the Commission or any person indemnified is permitted to apply to the appropriate district court of the United States which has venue in bankruptcy matters over the site of the nuclear incident. Again it should be pointed out that the site is where the occurrence takes place which gives rise to the liability, not the place where the damage may be caused *** " Report. p. 22.

${ }^{4}$ Atomic Industrial Forum, Financial Protection Against Atomic Hazards, The International Aspects, p. 52 (1959).

${ }^{5}$ Hearings before the Joint Committee on Atomic Energy, Governmental Indemnity and Reactor Safety, 85th Cong., 1st Sess., p. 181 (1957) (hereinafter referred to as "Hearings.")

${ }^{6}$ Hearings, p. 168. 
${ }^{7}$ Hearings, p. 182.

${ }^{8}$ Hearings, p. 97. It is significant to note that Mr. Haugh stated at that point the problem of the reactor operator who is concerned with any type of liability. He noted that the insurance contracts would cover "*** the instance where $* * *$ something happen[ed] out of the country and a suit is brought in the United States on that."

${ }^{9}$ The Atomic Industrial Forum study notes that "[T]o be adequate, the governmental indemnity must cover industry's liability to residents of the countries who suffer as a result of an accident at an installation based in the United States." p. 61. This is certainly the case and one of the major Congressional purposes is frustrated should the Act be said to be unclear on this point. The principal reason for the conclusion that there is coverage reached in the Forum study is the fact that Price-Anderson provides indemnity for "any legal liability." Arthur Murphy, Director of the study, in a recent article, has stated that the confusing sentence in the Report is "*** inconsistent with the flat coverage of any legal liability by the indemnity." Murphy, Liability for Atomic Accidents and Insurance, in Law and Administration in Nuclear Energy 75 (1959). In the testimony before the Joint Committee last year, Professor Samuel D. Estep, one of three authors of the comprehensive study of Atoms and the Law apparently relying upon the legislative history, stated that the problem of a reactor accident in the United States causing damage in a foreign country was unclear, presumably since he considered the phrase "any legal liability" directed at a different problem. Hearings before the Joint Committee on Atomic Energy, Indemnity and Reactor Safety, 86th Cong., 1st Sess., p. 77 (1959); Stason Estep, and Pierce, Atoms and the Law, 577 (1959). Professor Estep stated that there "surely ought to be" coverage and suggested a clarifying amendment. His statement that the phrase "any legal liability" covers only the question of time restrictions for claims seems to me erroneous since the language used, "any legal liability," seems intentionally broad. Additionally, should this very narrow reading be given to admittedly broad statutory language, the Congressional purpose would be frustrated.

Privacy Policy | Site Disclaimer

Last revised Friday, May 27, 2005 
Attachment 1 to

Enclosure 3 of

MDO-723-0057

PAGE 12

This Page Intentionally Left Blank

PRE-DECISIONAL - For Planning and Discussion Purposes Only 
CONCURRENCEIDESIGN CHECK FORM FOR DOCUMENT NO.

MDO-723-0057-Rev1

Date: 2/15/2006

DOCUMENT TITLE: $\quad$ Experiences and Considerations with Irradiation Test Performance in an International Environment

REFERENCES MDO-723-0030 / ENCLOSURES:

B-MT(EDT)S-015

MDO-723-0021/

B-MT(SRME)-21

MDO-723-0006 /

B-MT(EDT)S-005

MDO-723-0011/

B-MT(SRME)-53
[1] Summary of Candidate Reactor Facilities Feasibility Study for an Overseas High Fluence Irradiation Test,

[2] Space Reactor Materials Irradiation Testing Project Summary Report: "Irradiation of Advanced Structural Materials in JOYO to Support the Development of a Space Fission Reactor", PNNL Project 48552, Report \# PNNL-15610, February 2006.

[3] Application of Nuclear Hazard Indemnity Clause to the Irradiation of Space Reactor Materials in the JOYO Experiment Fast Reactor Project, Painter, CL. March 2005.

1. ADSARS: PERMANENT RECORD: Yes $\mathrm{X}$ No Repository MFLIB Corporate Author: KAPL NR PROGRAM 08S

Key Words: JOYO Need to Know Categories

Available Sites:

Design File Location(s)

\section{DESIGN CHECK}

Type of Check

\begin{tabular}{ll}
\hline \hline A. & No check considered necessary \\
\hline B. & Check vs. previous results/issues \\
\hline C. & Checked calculations made \\
\hline D. & Checked computer input and/or output \\
\hline E. & Computer Programs approved/qualified \\
\hline F. & Performed independent audit \\
\hline G. & Spot checked significant points \\
\hline H. & Reviewed methods used \\
\hline I. & Reviewed results for reasonableness \\
\hline J. & Comparison with test data \\
\hline K. & Reviewed vs. drawings \\
\hline L. & Verified procedures \\
\hline M. & Technical content reviewed \\
\hline N. & Management verification of adequate \\
review by others \\
\hline O. Performed Lessons Learned Search \\
\hline P. Used Measurement Uncertainty Methods \\
\hline Q. Other Checks (Describe) \\
\hline
\end{tabular}

3. CONCURRENCE REQUIREMENTS: ARP MANAGER

NUCLEAR ENGINEERING

REACTOR TH/MECH DESIGN

REACTOR EQUIPMENT

POWER PLANT MECHANICAL

POWER PLANT ELECTRICAL

FINANCE

NEW SHIP PROGRAMS

PROGRAM COORDINATION

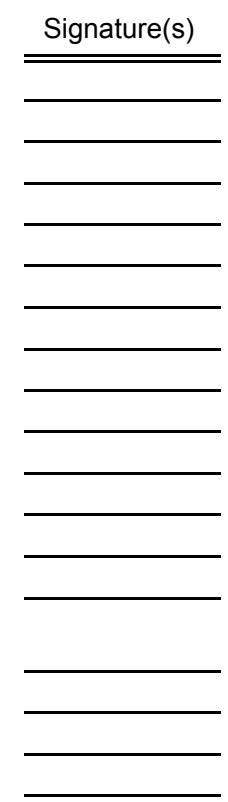

Comments: (Including Reference to Check Document If Appropriate)

Indicate signatures required by $\mathrm{X}$ :

NCSG

ADVANCED CONCEPTS

NOISE \& ELEC. TECH.

SHIELDING

REACTOR SAFETY

TO

RSO

FSO

MDO
FLUID DYNAM

STRUC. ENGRG DRAFTING

QA

OTHER

BETTIS

BPMI

ADMIN REVIEW

Cognizant Manager

(Must Be Subsection or Higher for External Letters)

4. AUTHORIZED CLASSIFIER:

Reviewed By:

5. RELATED SUBJECTS:

UTRS Implication $(\mathrm{Y} / \mathrm{N})$

Safety Council Review (Y/N)

$\mathrm{N}$

Commitment Made (Y/N)

Design Basis Info. $(\mathrm{Y} / \mathrm{N})$

Design Review (Y/N)
CLASSIFICATION: UNC

\begin{tabular}{|c|c|c|}
\hline $\mathrm{N}$ & Commitment Complete $(\mathrm{Y} / \mathrm{N})$ & $\mathrm{N}$ \\
\hline $\mathrm{N}$ & UTRS Doc. \# & \\
\hline
\end{tabular}

\section{Distribution:}


* electronic distribution only

$\underline{\mathrm{NR}}$

DI Curtis (5)

J. D. Yoxtheimer

J.P. Mosquera

S.T. Bell

C.H. Oosterman

PNR

H.A. Cardinali

J.F. Koury

J.A. Andes

JP Bannon

SNR

D. Potts

D. Clapper

G.M. Millis

H. Miller

BETTIS

MJ Zika*

CD Eshelman*

DP Hagerty*

WL Ohlinger*

SD Harkness*

JE Hack *

WS Saylor

R Baranwal

AM Tullai

DC Stambolis*

GD Carpenter*

CM Rodenbush*

DC Noe*

RA Reitz*

J Molitoris*

$\checkmark$ Perone*

M Brewer*

$J$ Mariner*

ADSARS/LIB
KAPL

MJ Wollman*

DF McCoy*

C Dempsey*

J Ashcroft*

H Schwartzman*

SZ Hayden*

M Wheeler*

J Prybylowski ${ }^{*}$

KC Loomis*

C Jordan*

RA Mulford*

CM Regan*

$S$ Simonson

BC Campbell*

L Kolaya*

$Y$ Ballout

GA Newsome

MH Lane

RS Northey

SM File

ADSARS 